\title{
Ene-Yne Metathesis of Allylphosphonates and Allylphosphates: Synthesis of Phosphorus-Containing 1,3-Dienes
}

\author{
Laurence N. Rohde, Jr., Thérèse H. Wild, and Steven T. Diver* \\ Department of Chemistry, University at Buffalo, the State University of New York, \\ Amherst, NY, 14260-3000
}

\section{SUPPORTING INFORMATION}

NMR Spectra appears on the following pages 


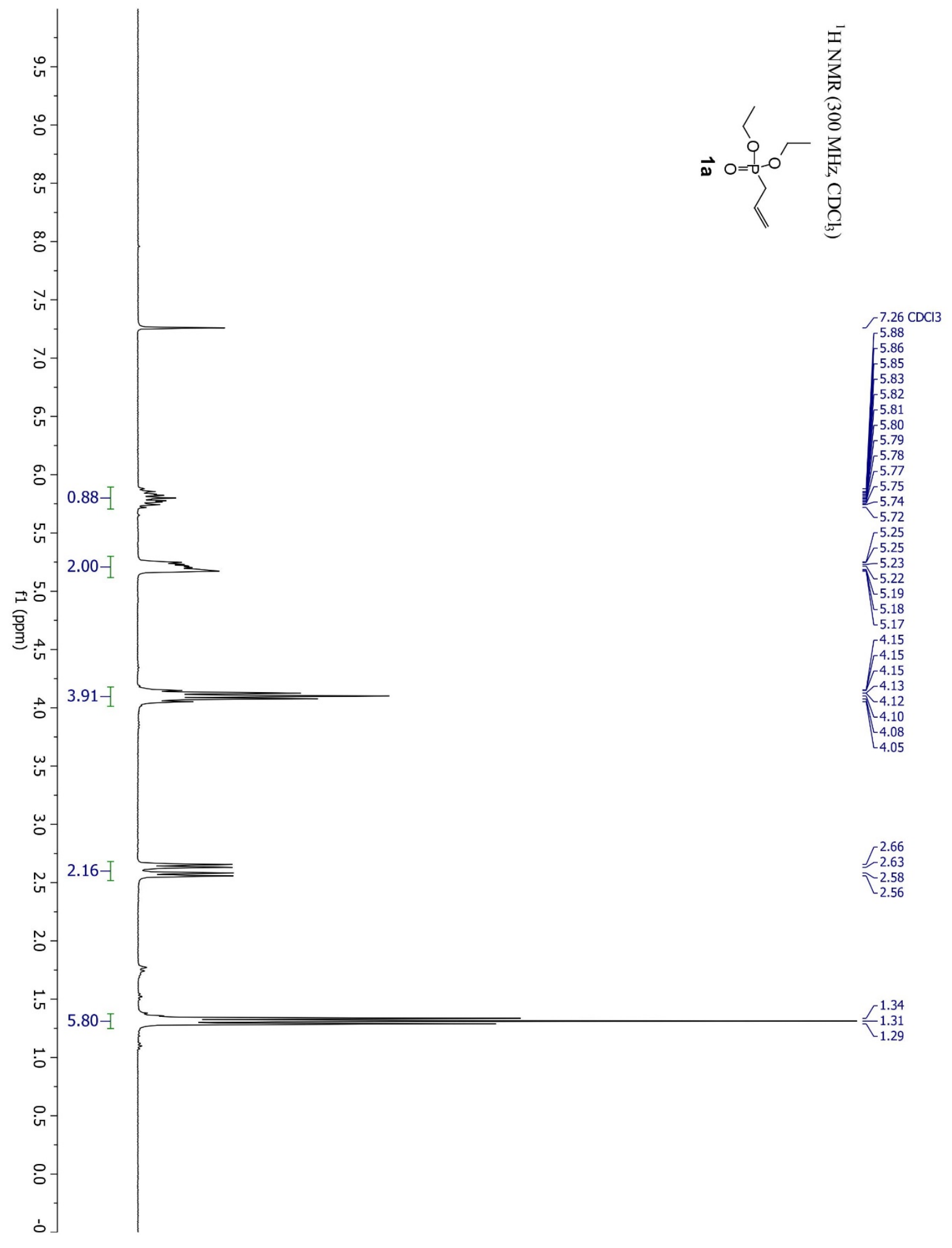




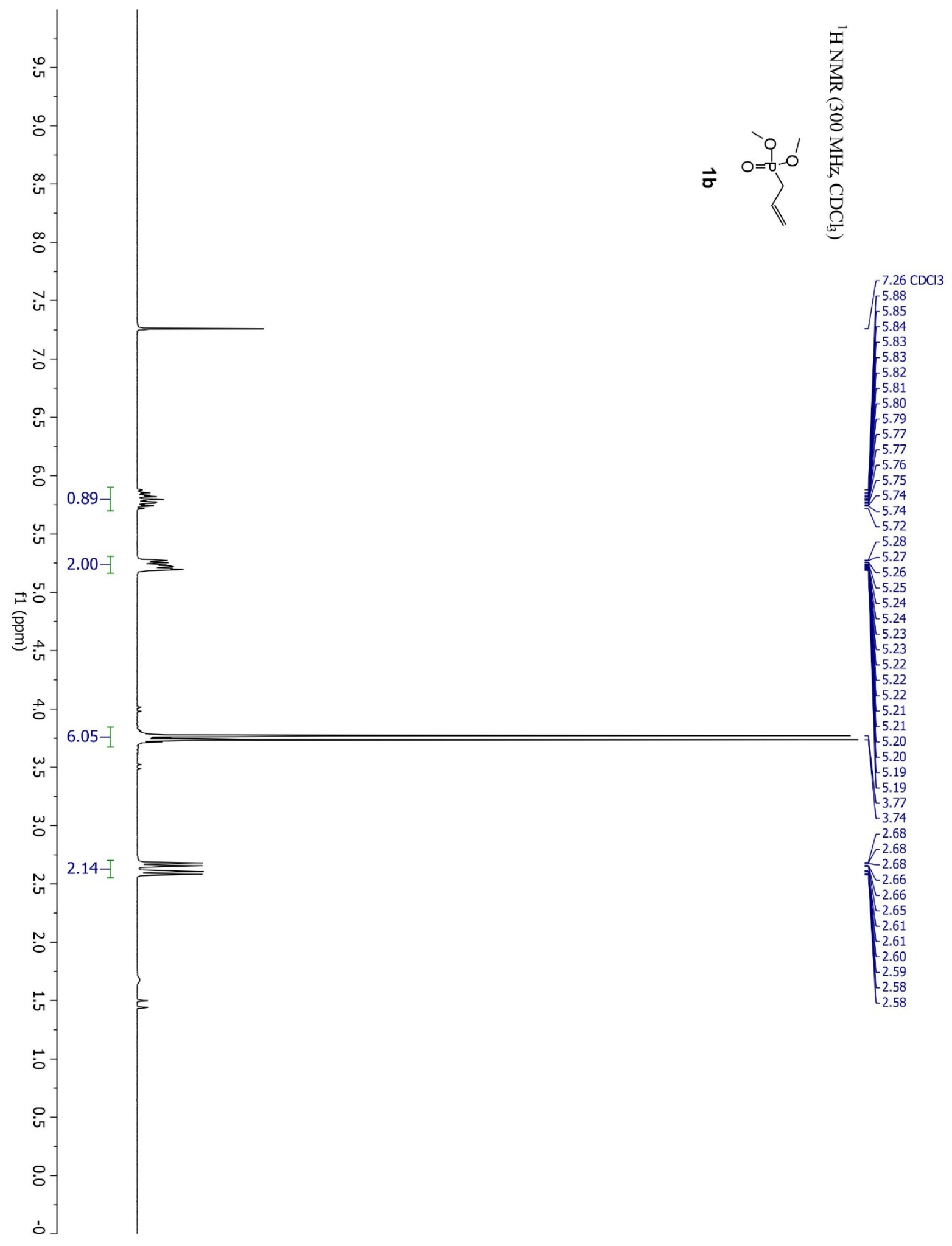




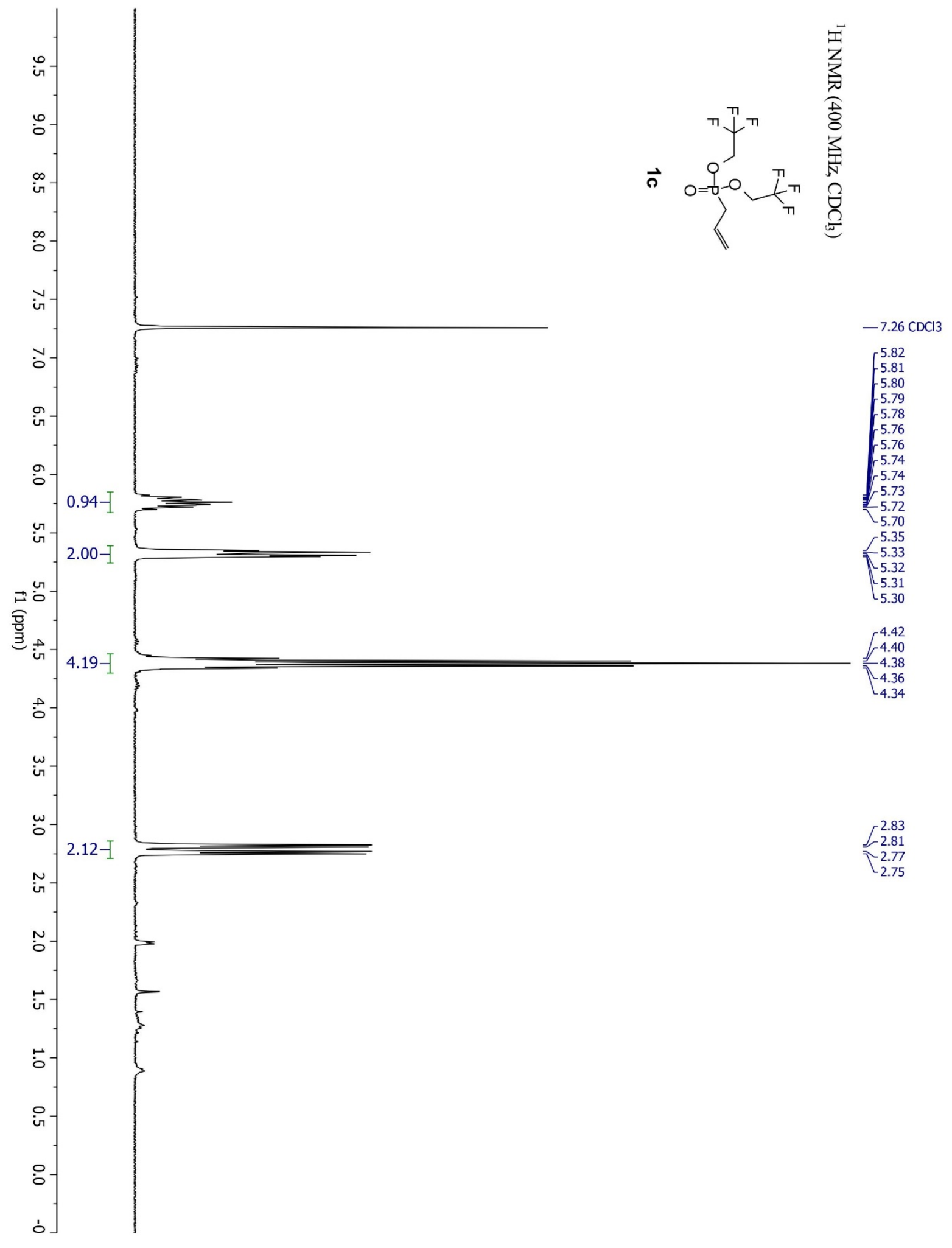




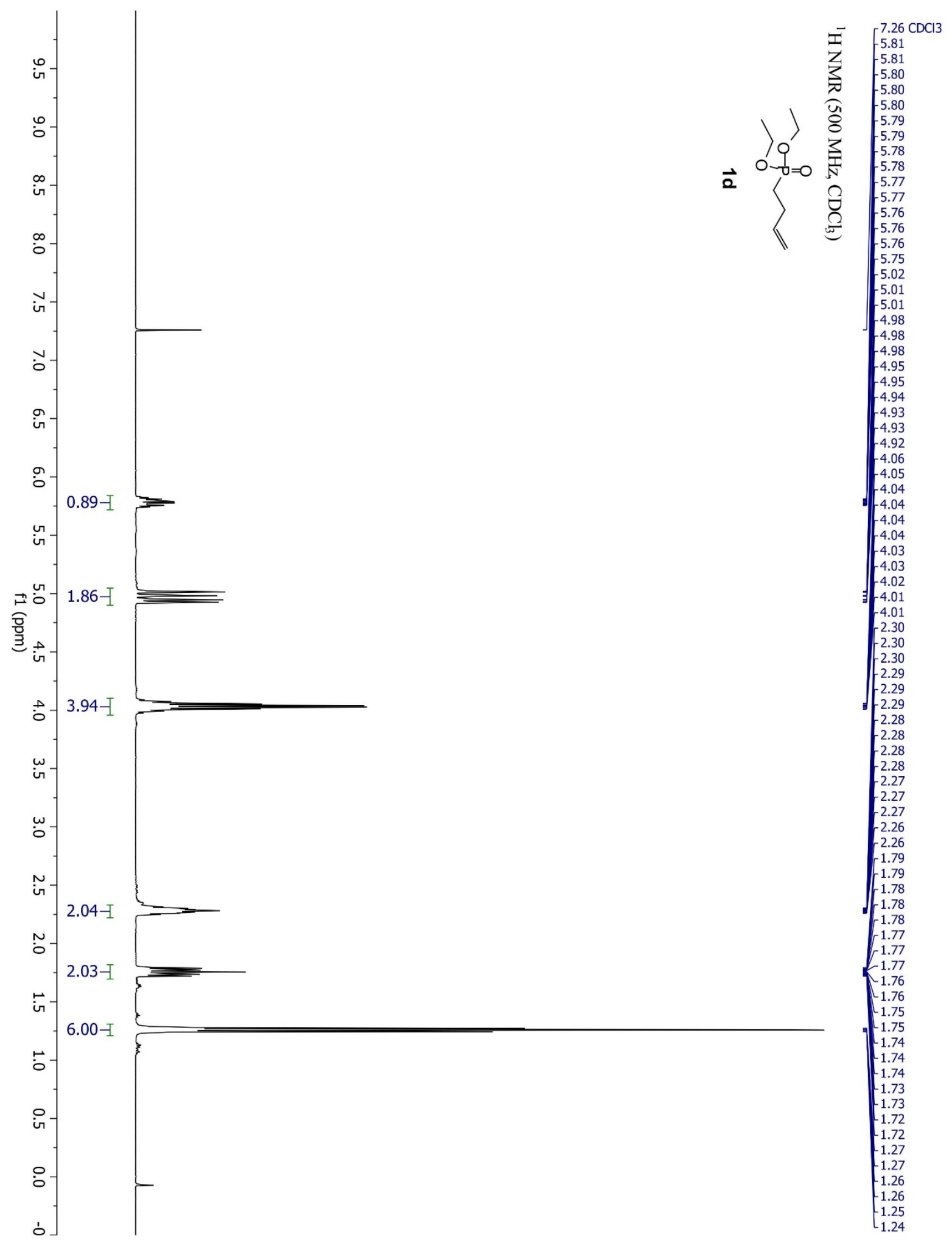




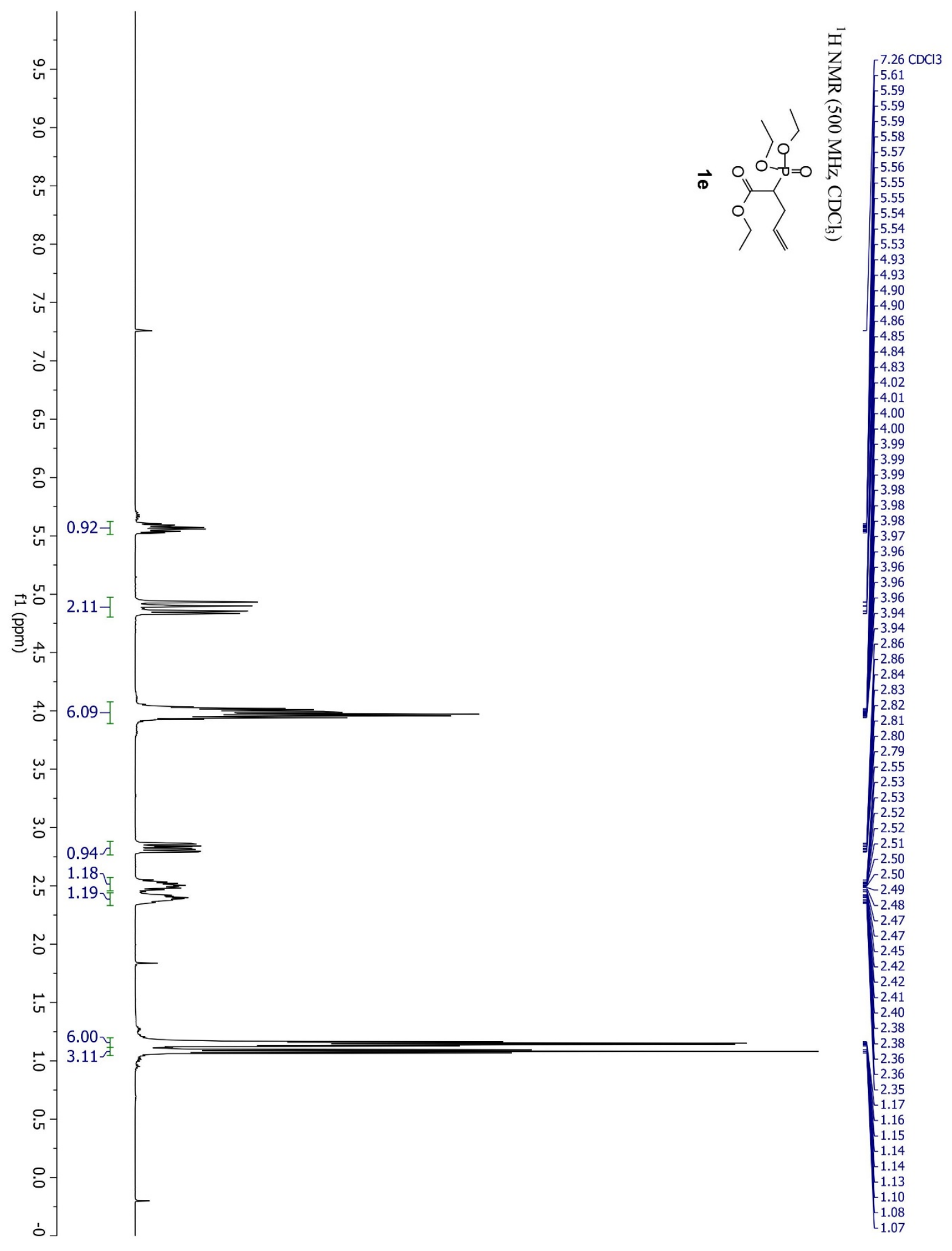




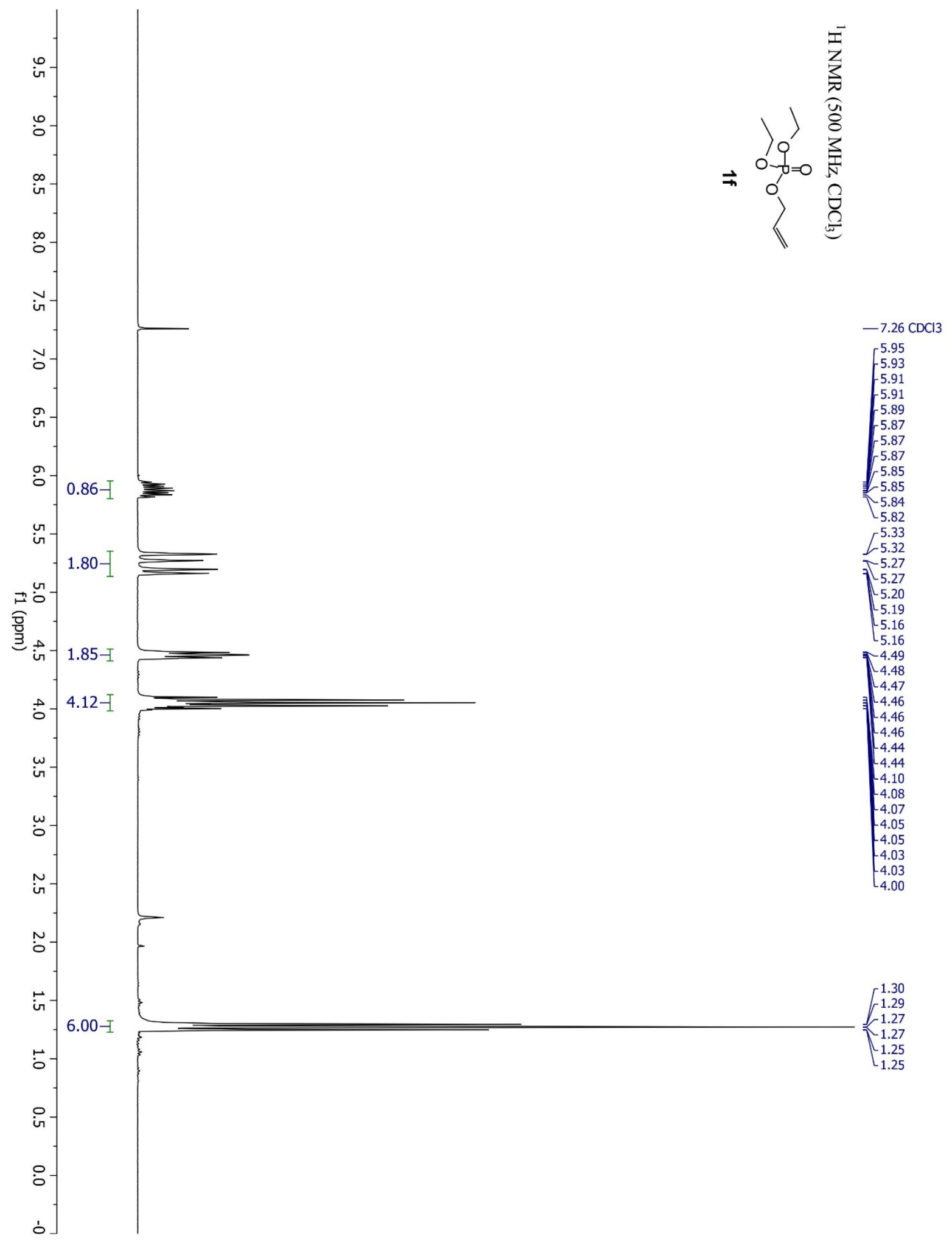




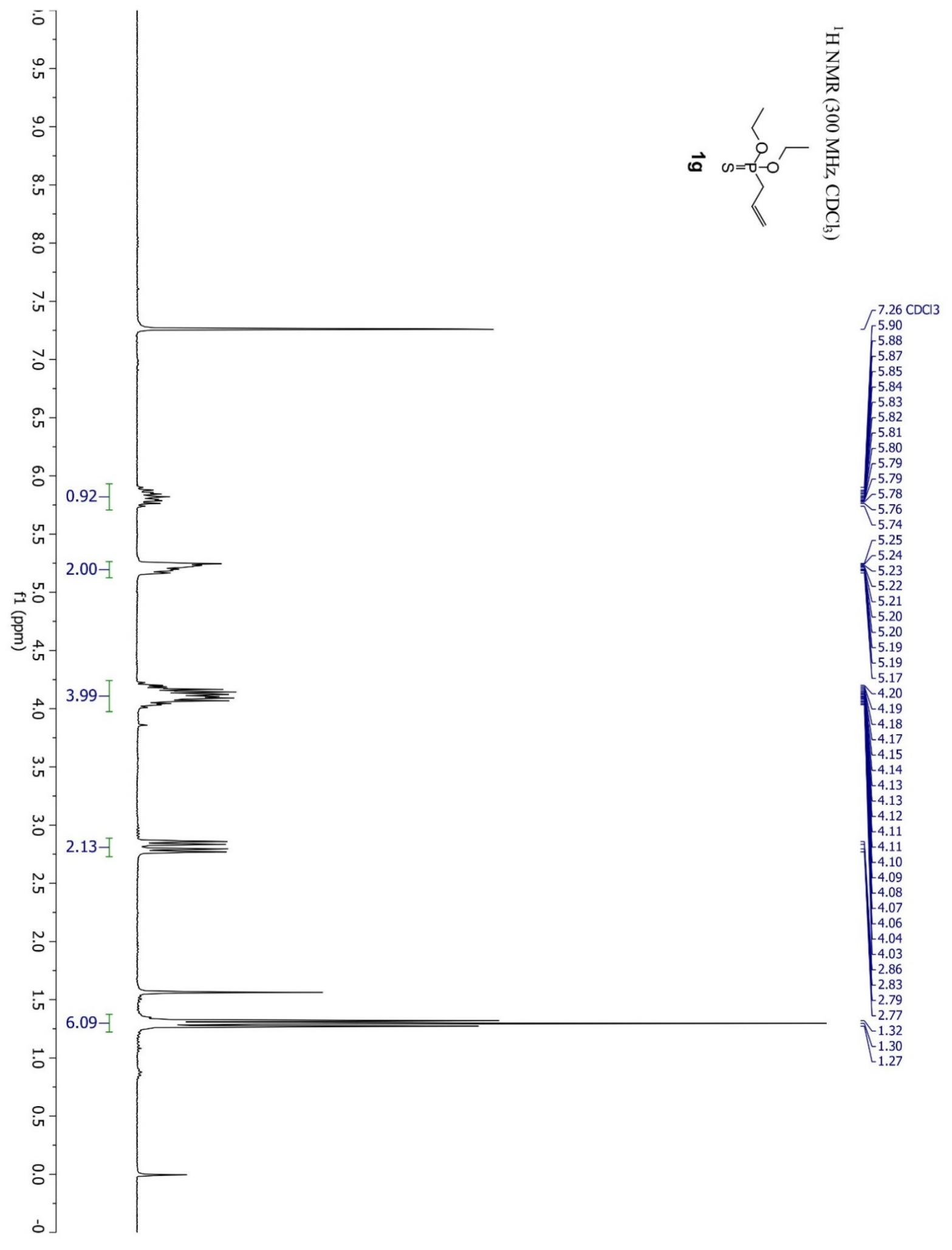




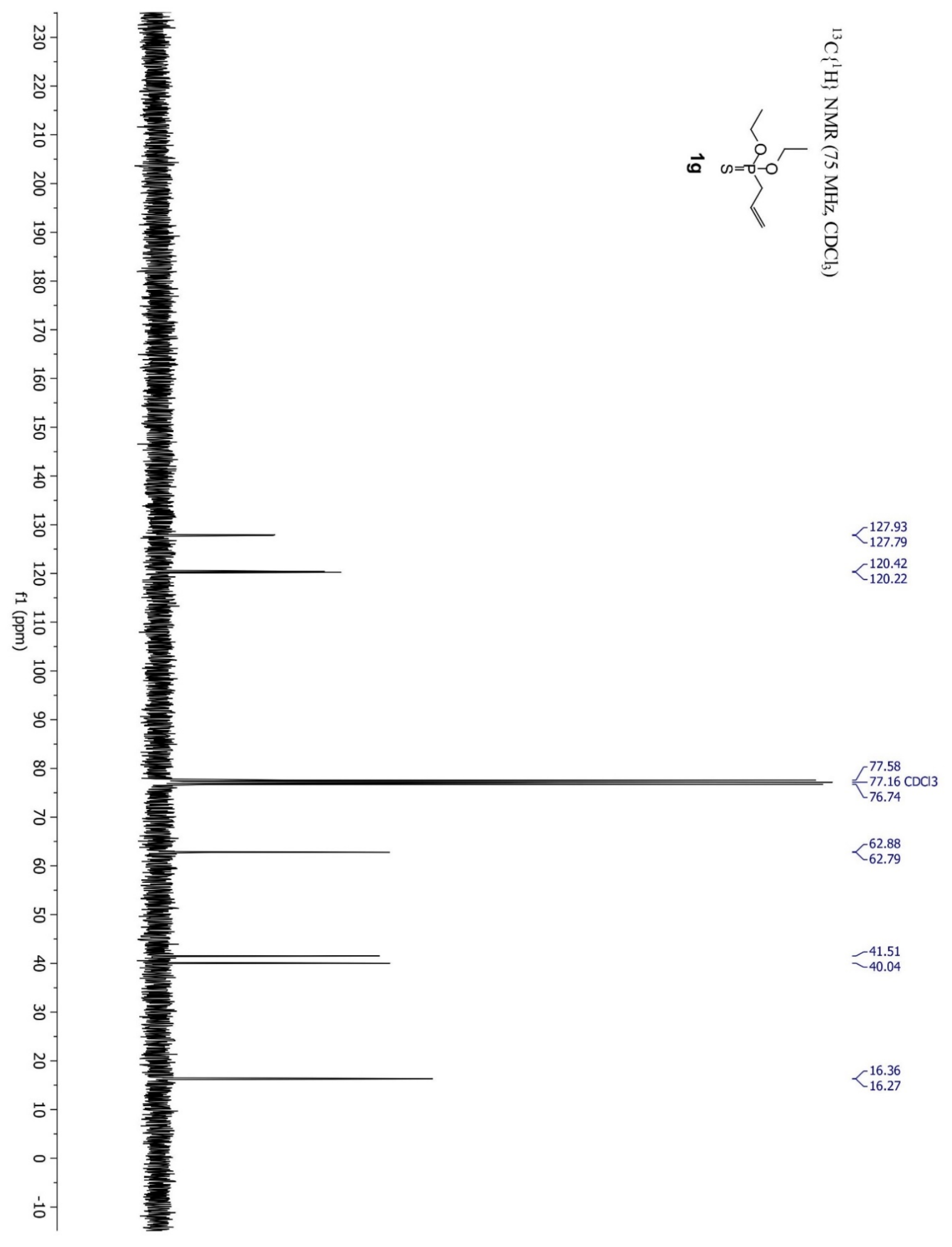




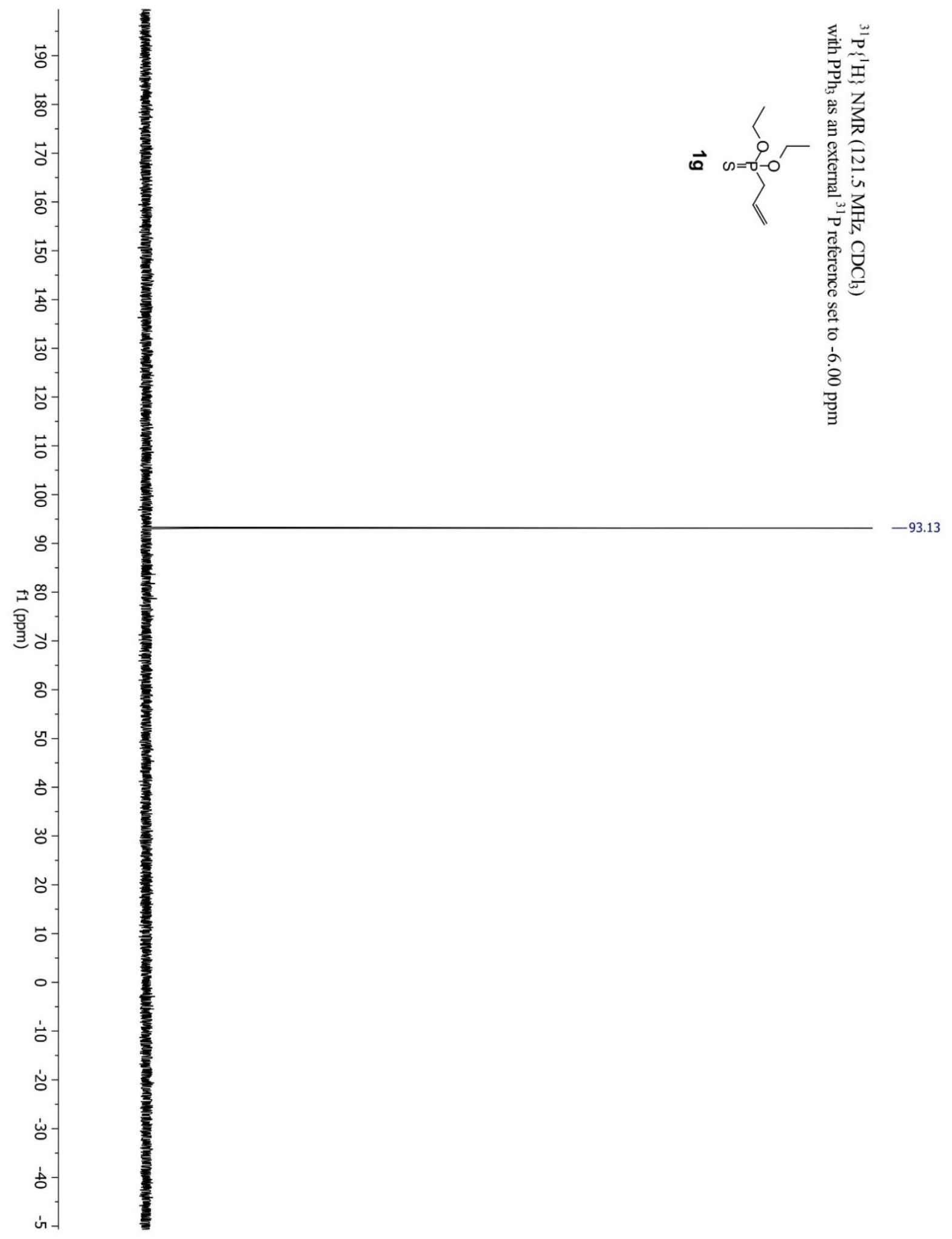




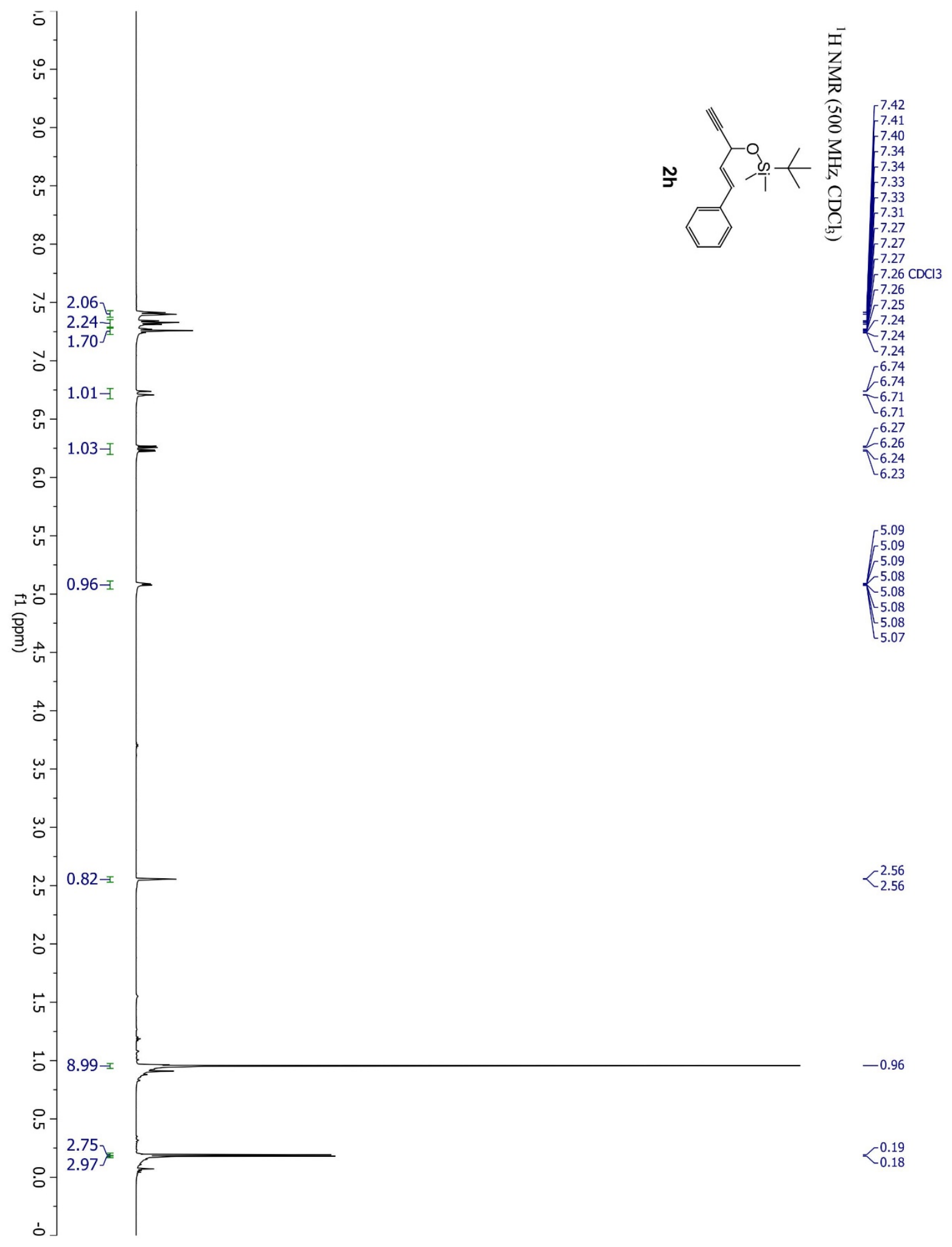




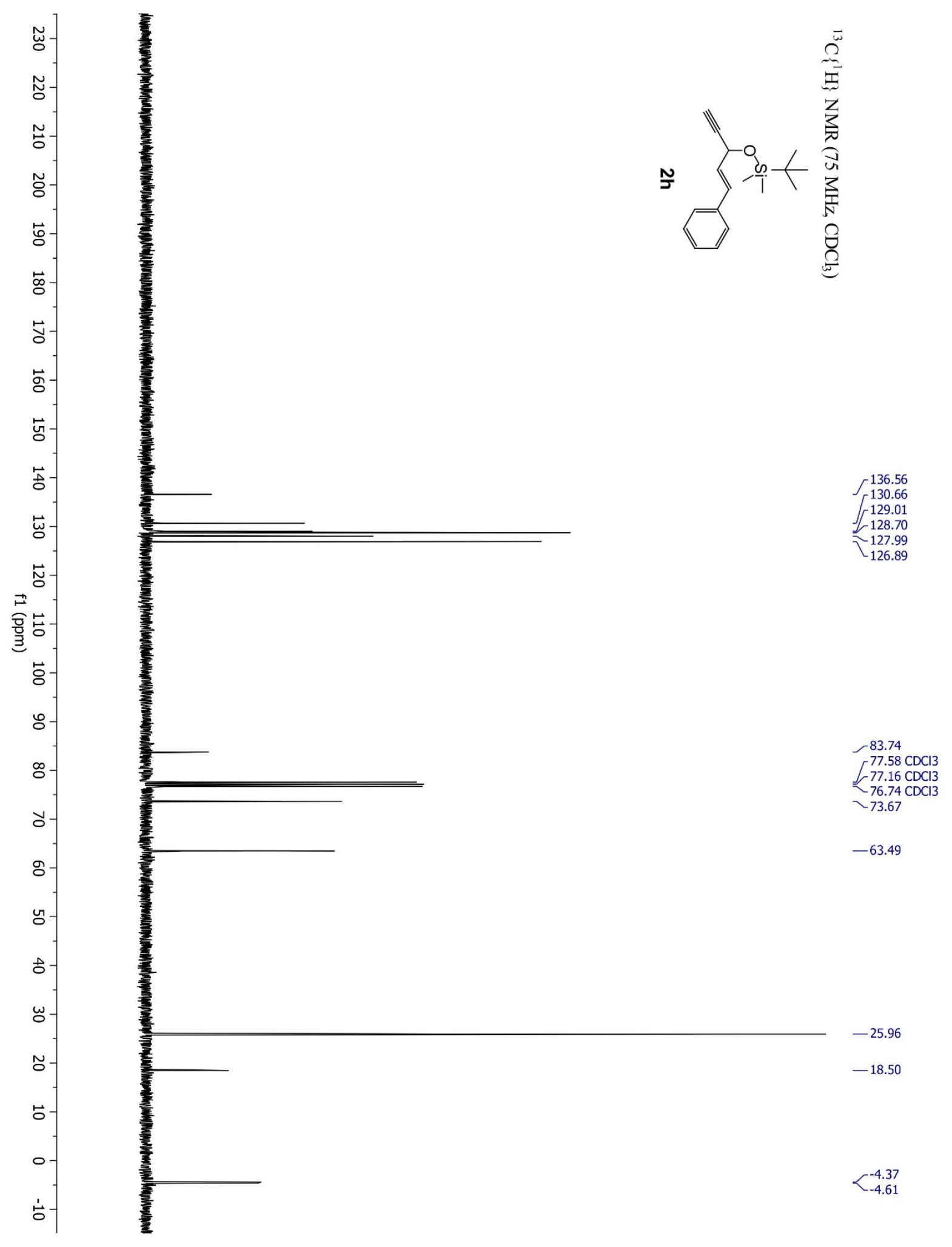




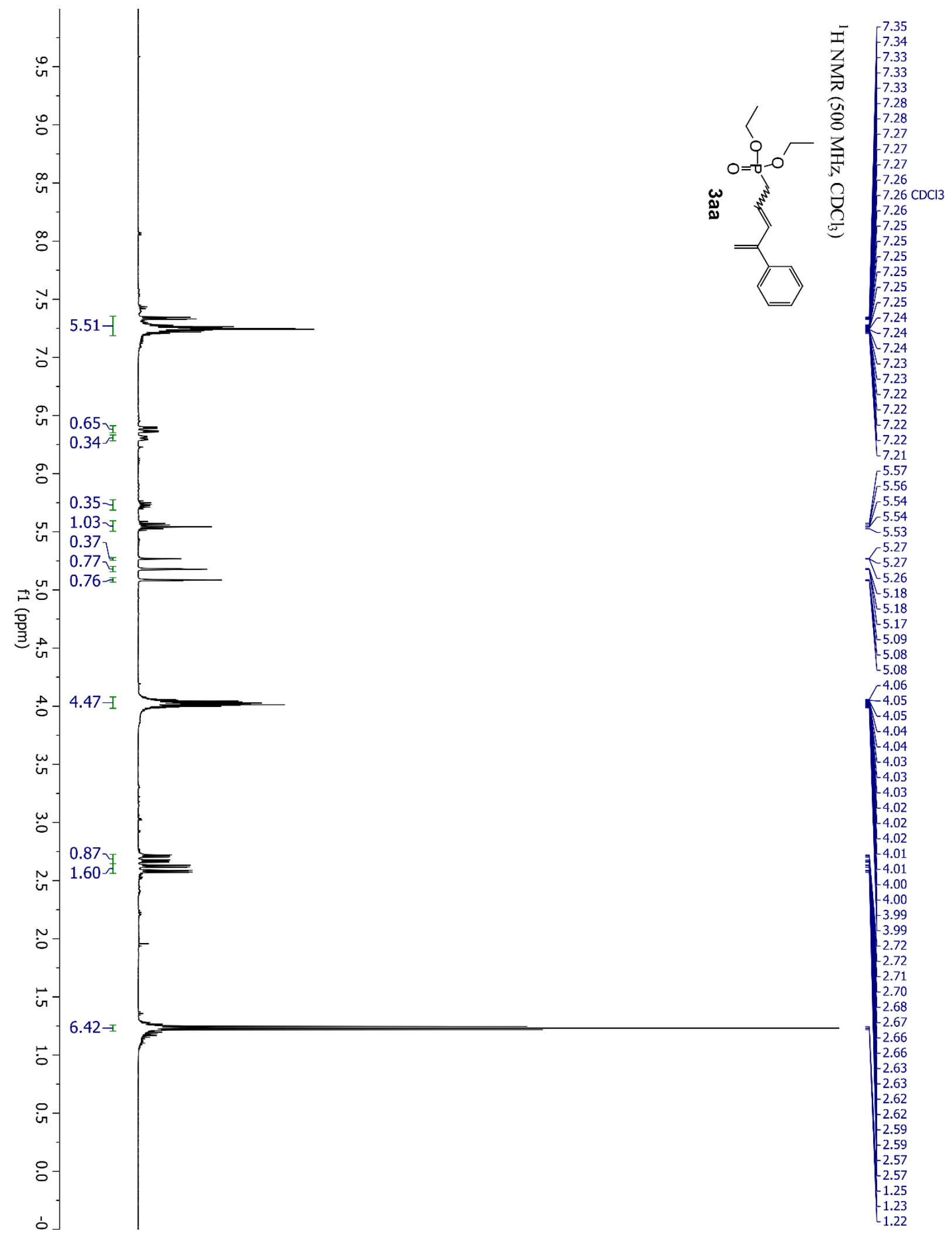




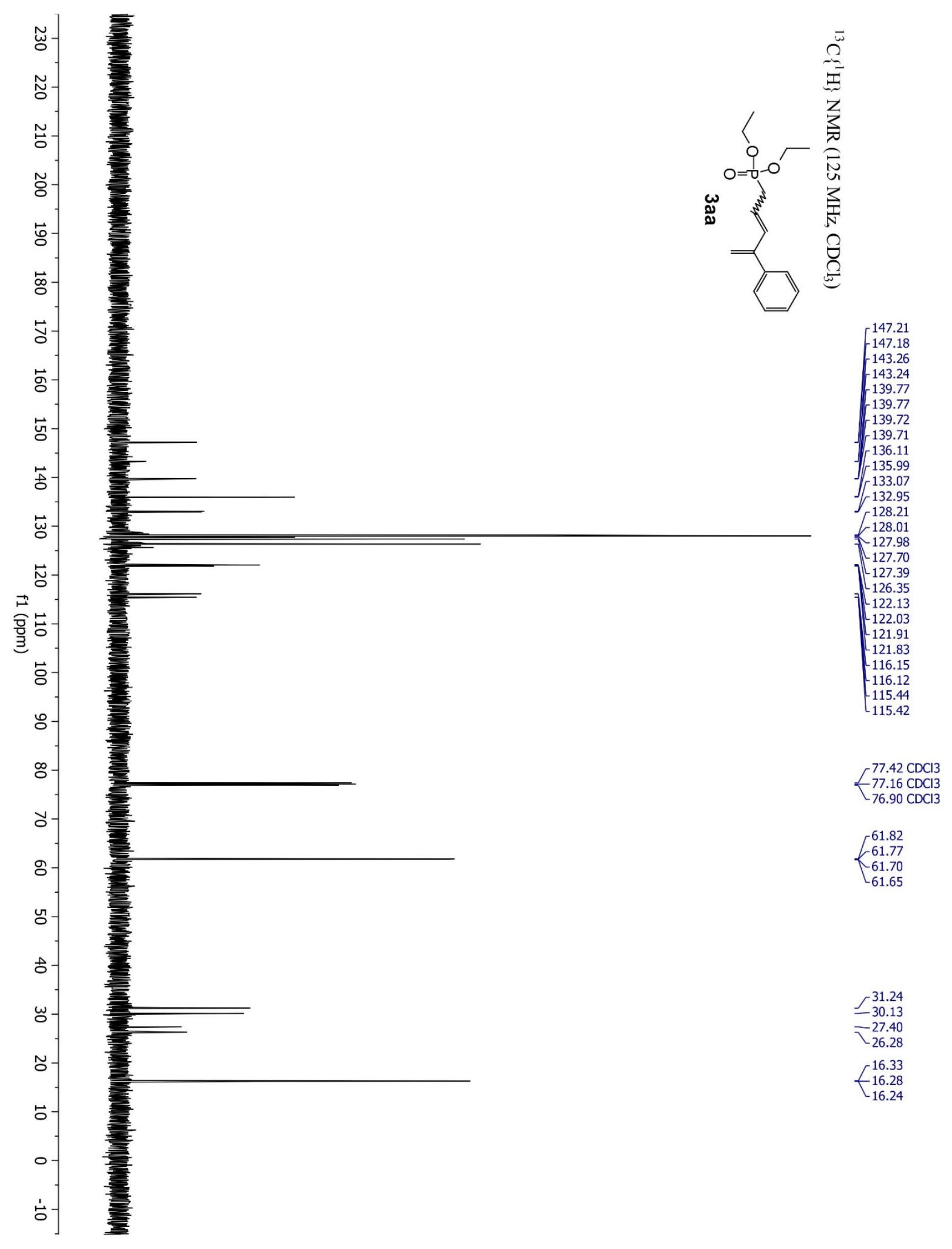




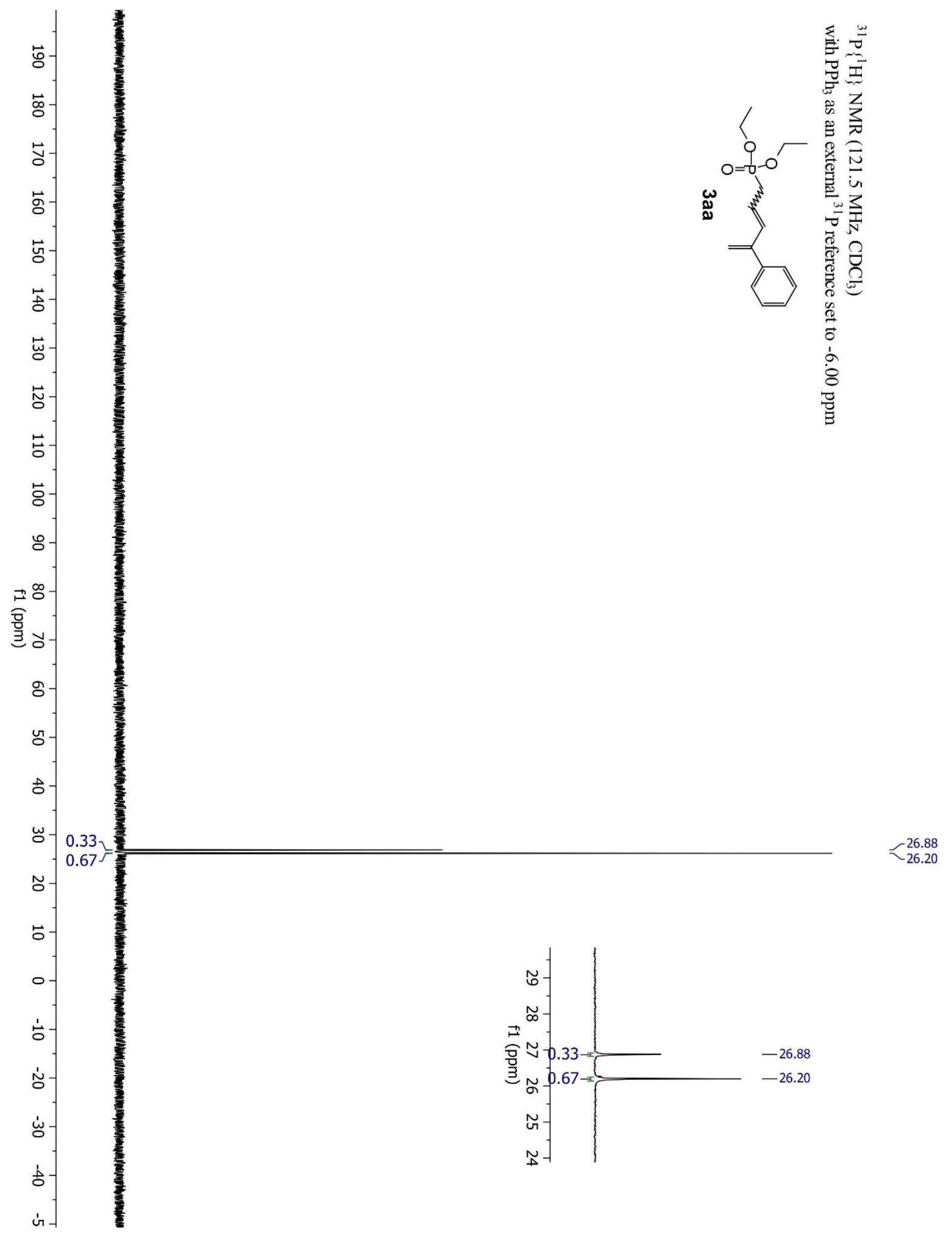




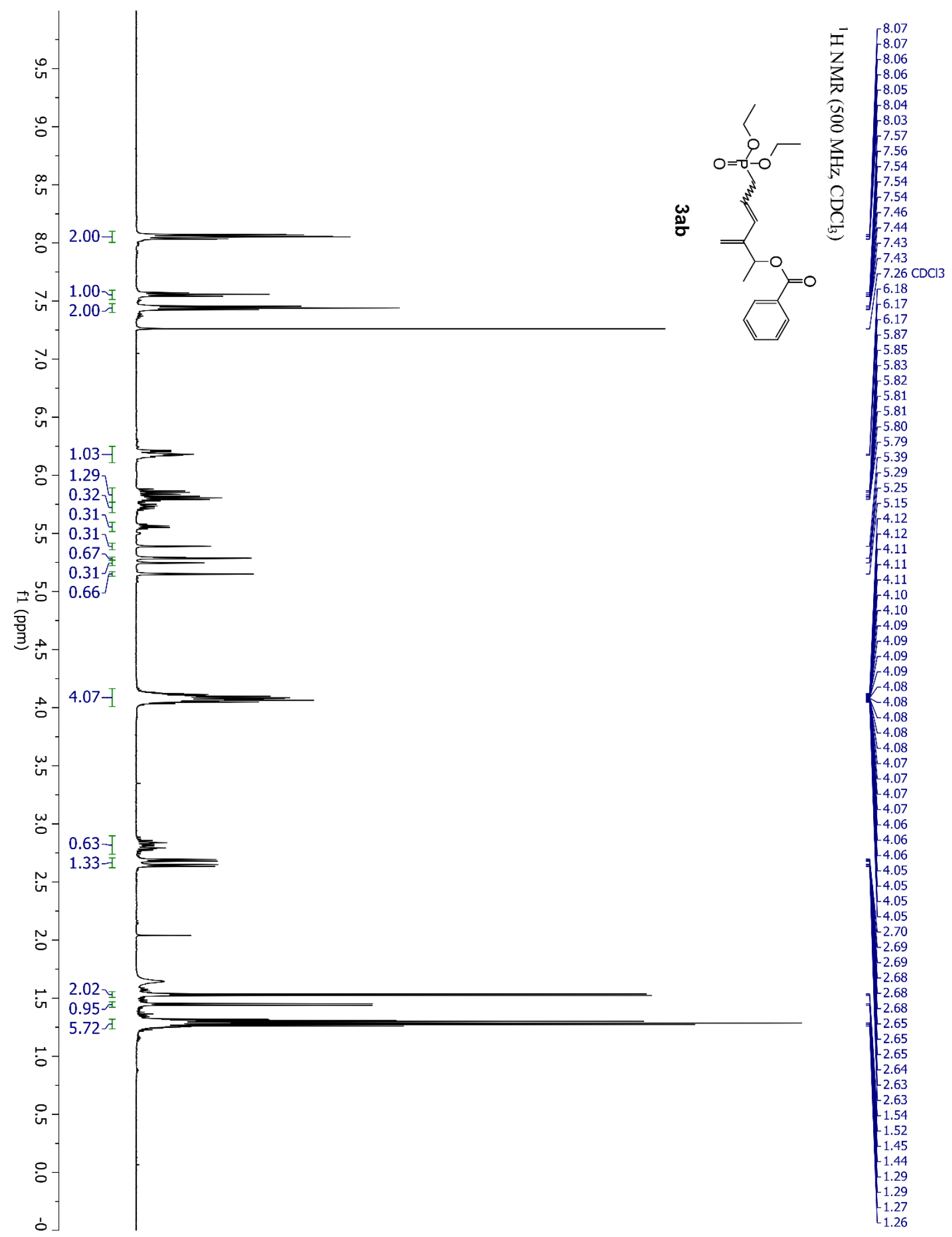




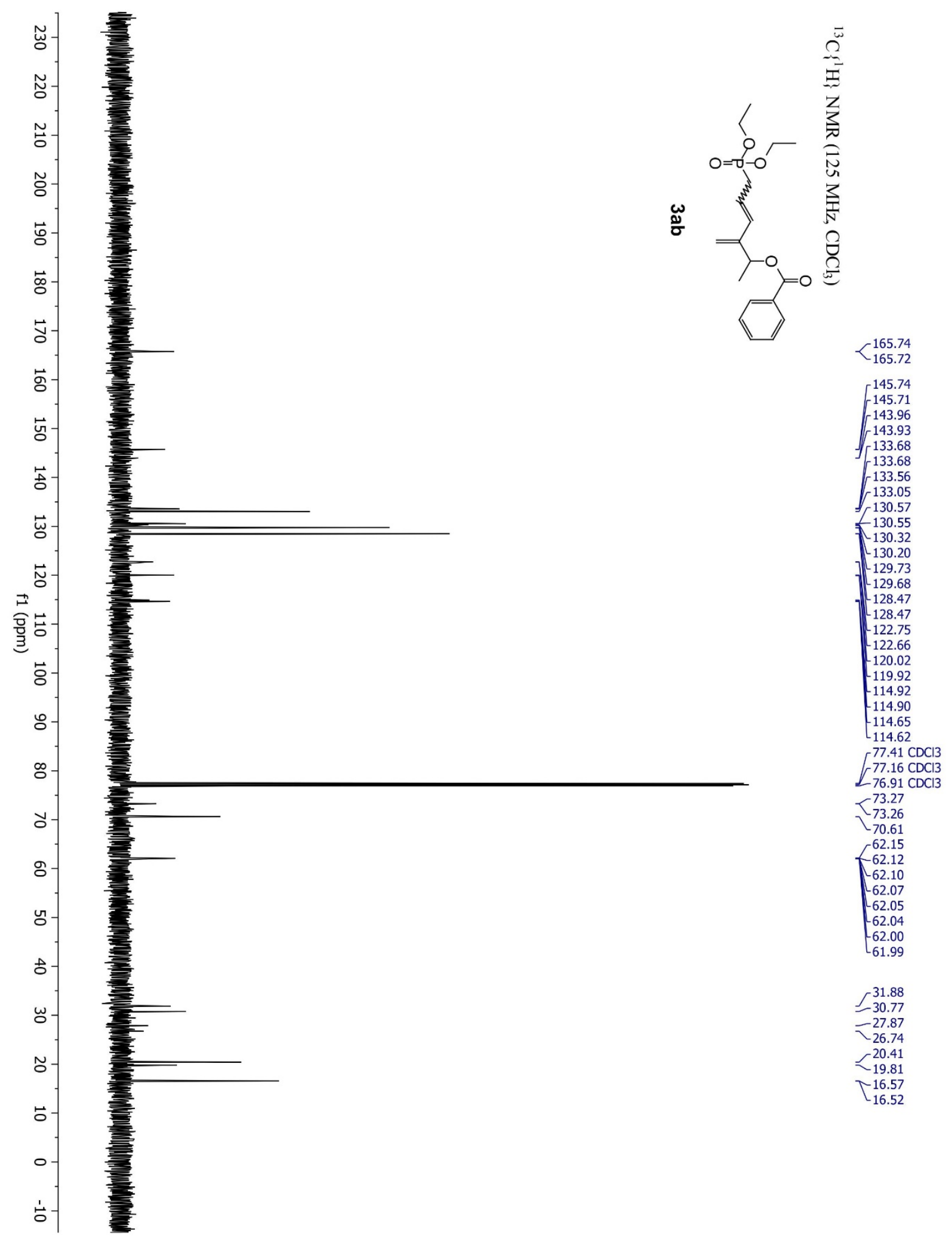




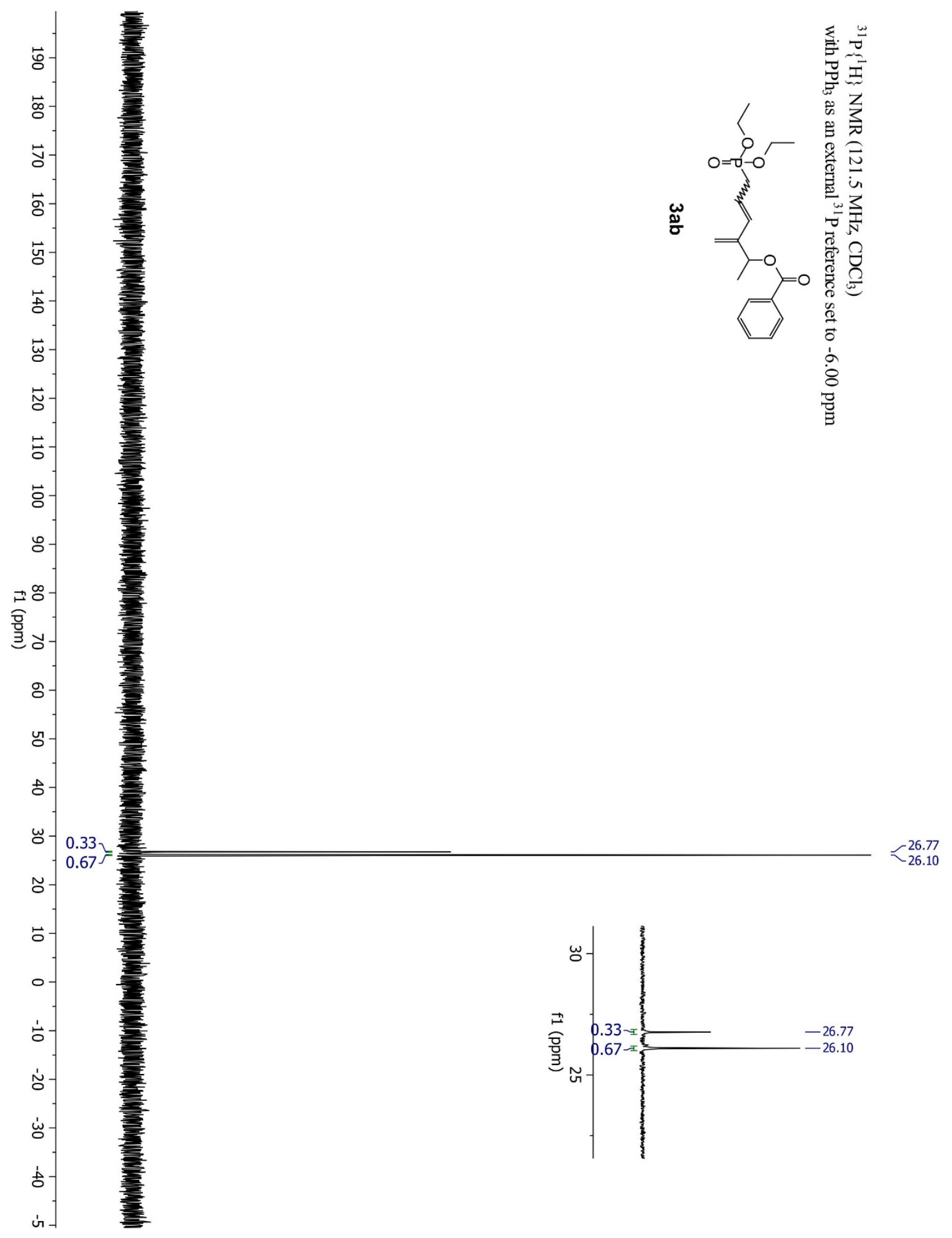



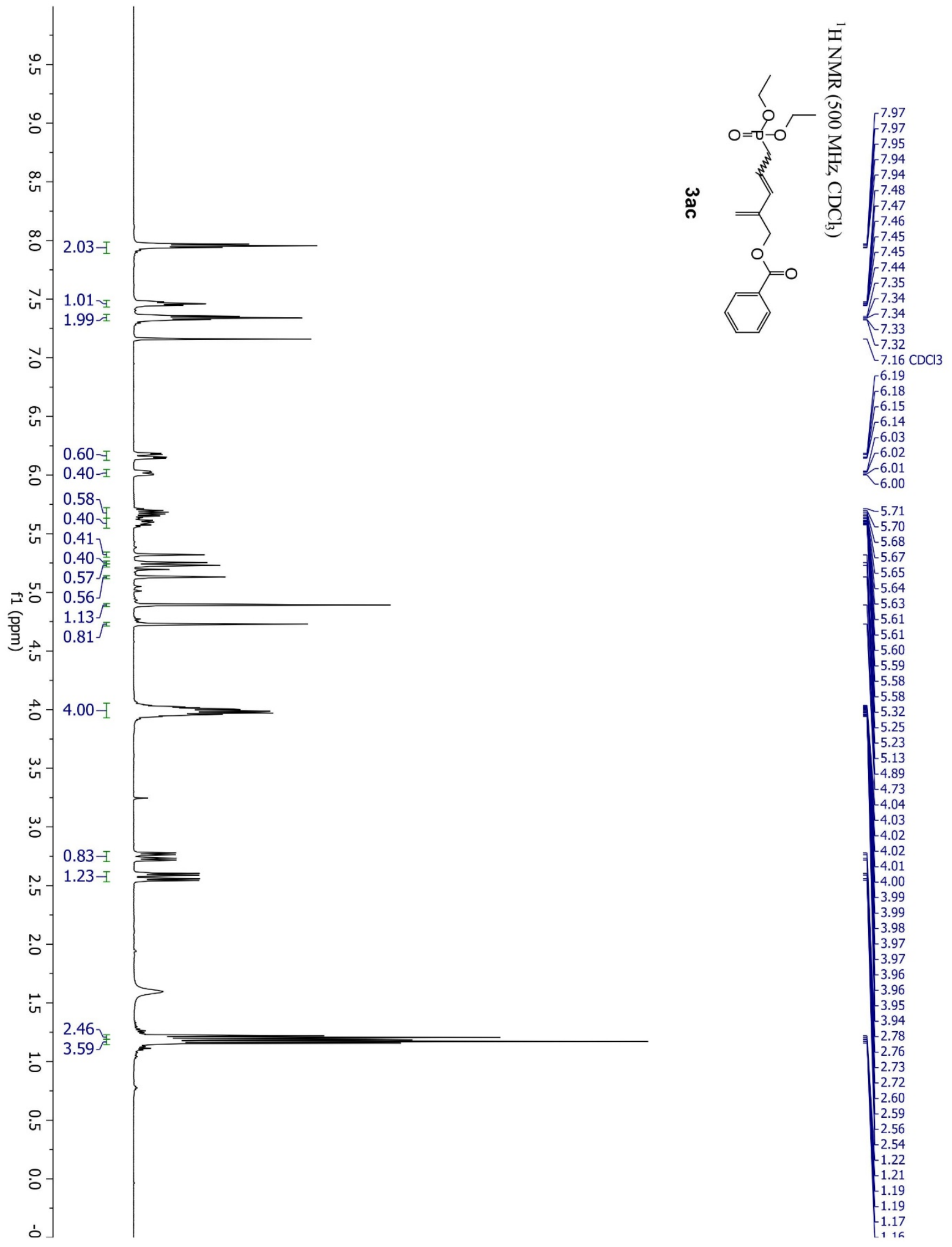


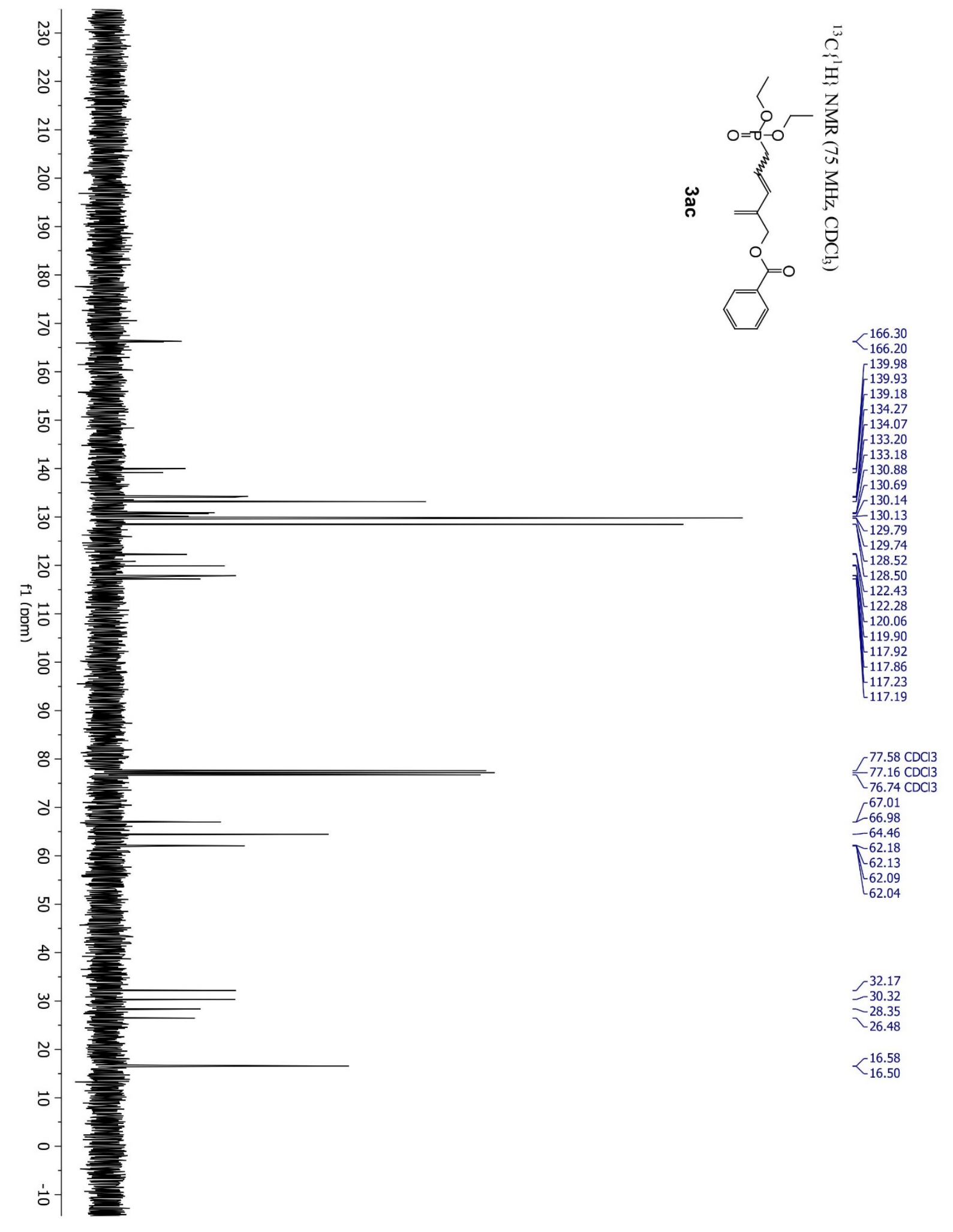




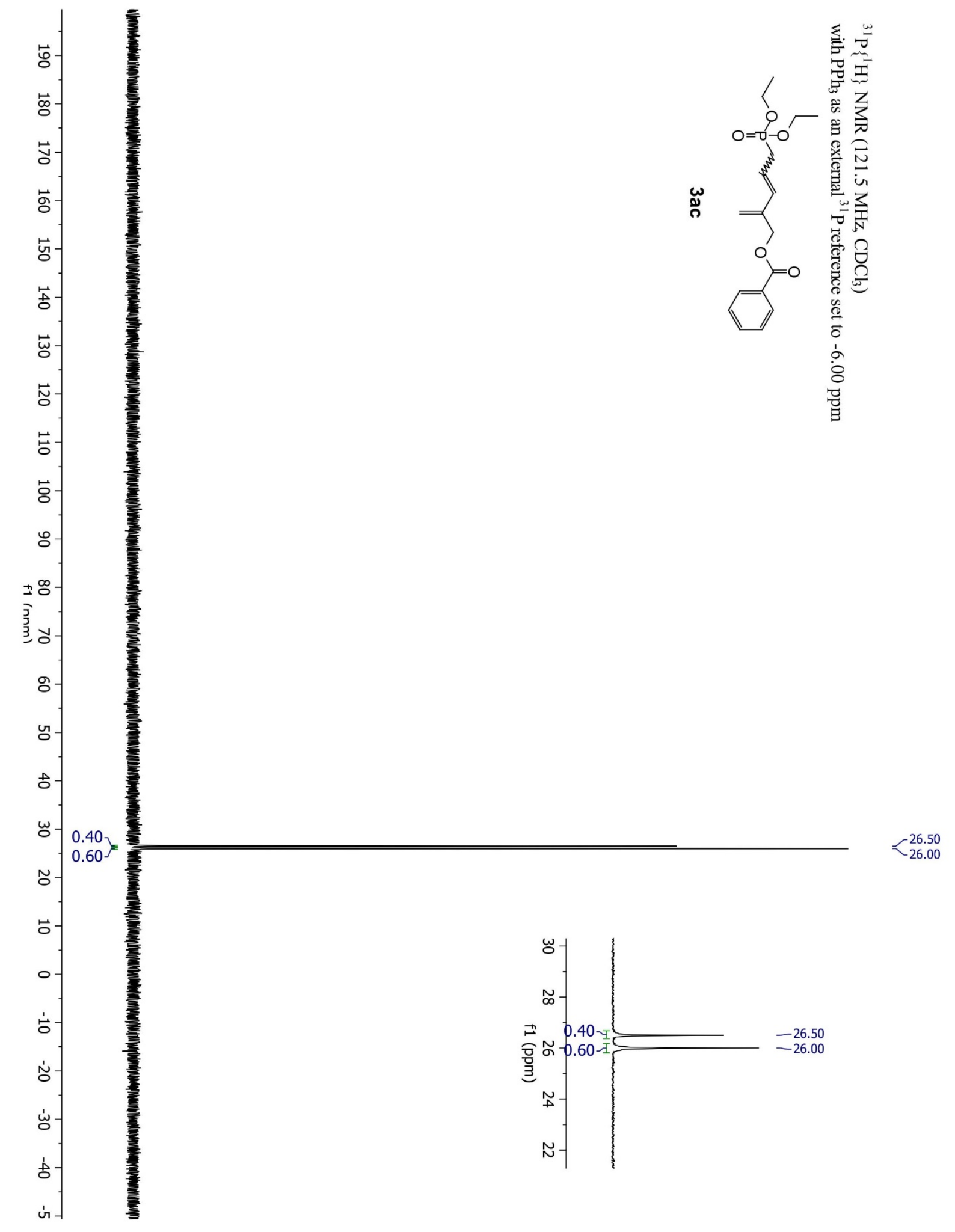




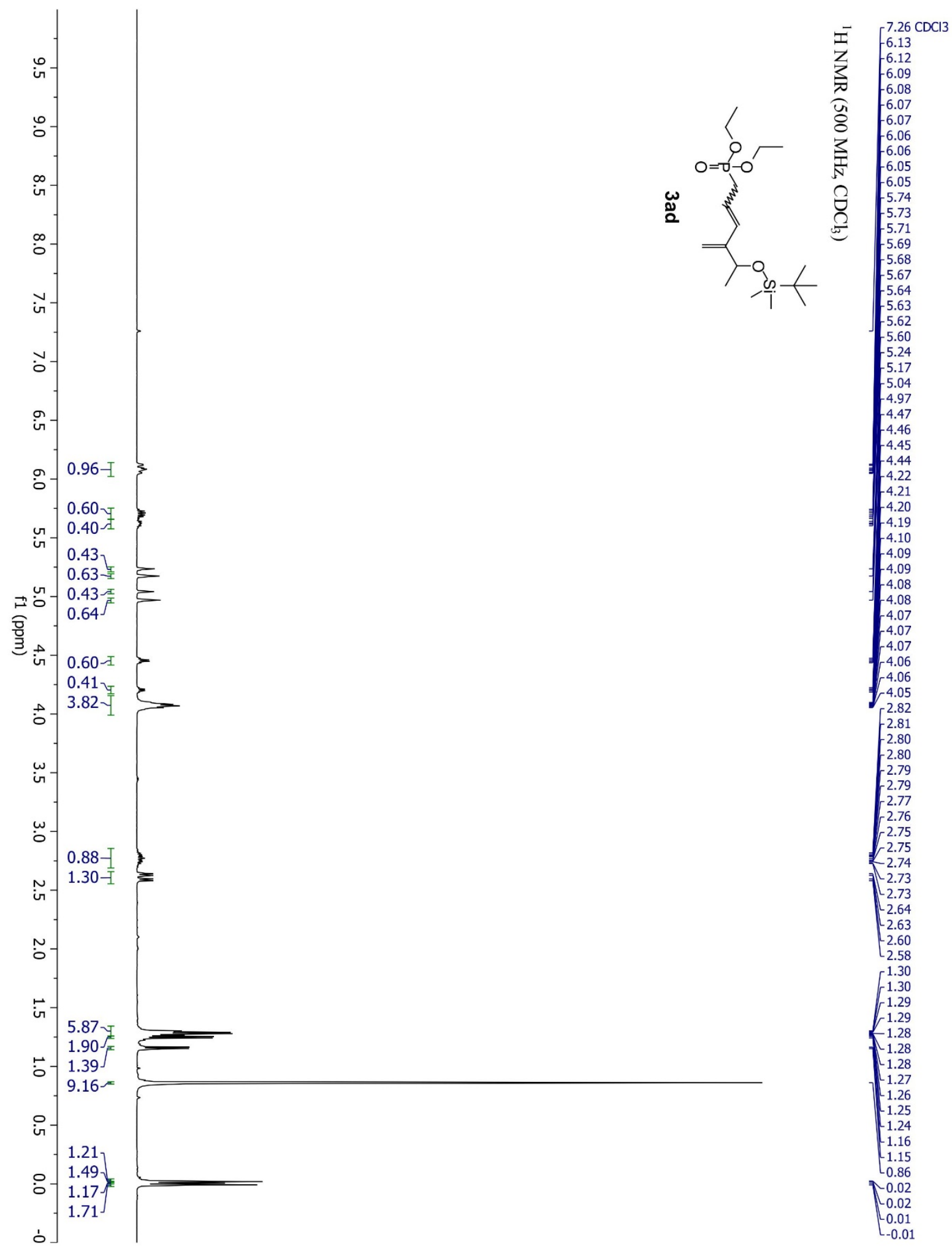



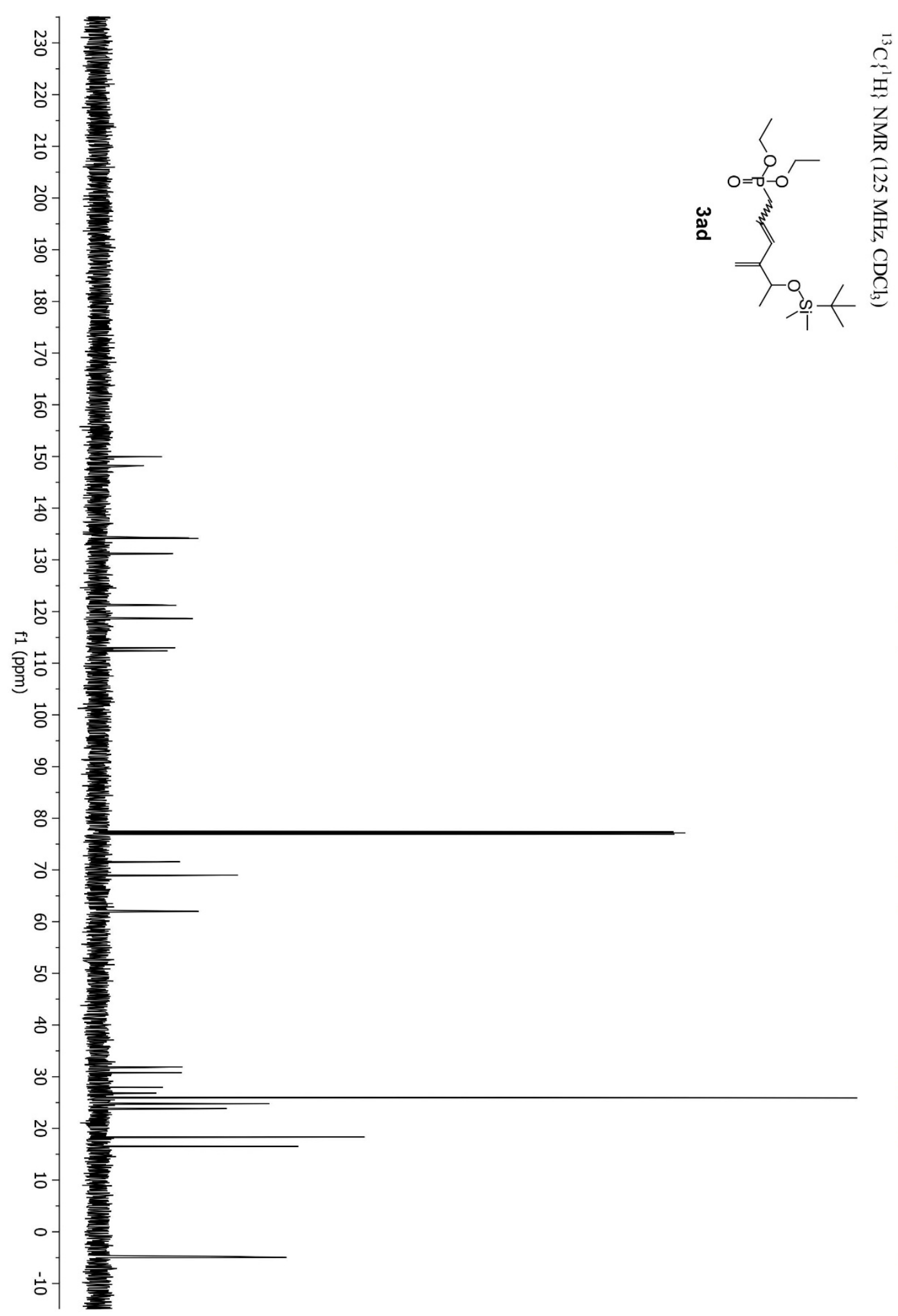

149.99
$L_{149.96}$
$\Gamma_{148.21}^{148.24}$

134.24 $-134.12$ $\left\ulcorner_{131.12}^{131.23}\right.$ 121.29 $L_{121.20}^{121.29}$ ${ }^{118.70}$ 118.60 $-112.99$ $-112.96$ 112.38

$77.41 \mathrm{CDCl} 3$ $\begin{array}{r}77.16 \mathrm{CDCl} 3 \\ -76.91 \mathrm{CDCl} 3 \\ \hline\end{array}$ $\chi_{71.57}^{71.58}$ $<_{71.57}$

$\checkmark 69.00$

62.06

$-62.04$

61.98

61.95

$-61.92$

$-61.90$

61.87

31.89
30.77

27.94

26.82

25.91

25.90
24.77

18.33

16.56

16.55

16.52
16.50

-4.78
-4.83

$-4.90$

-4.90
-4.98 


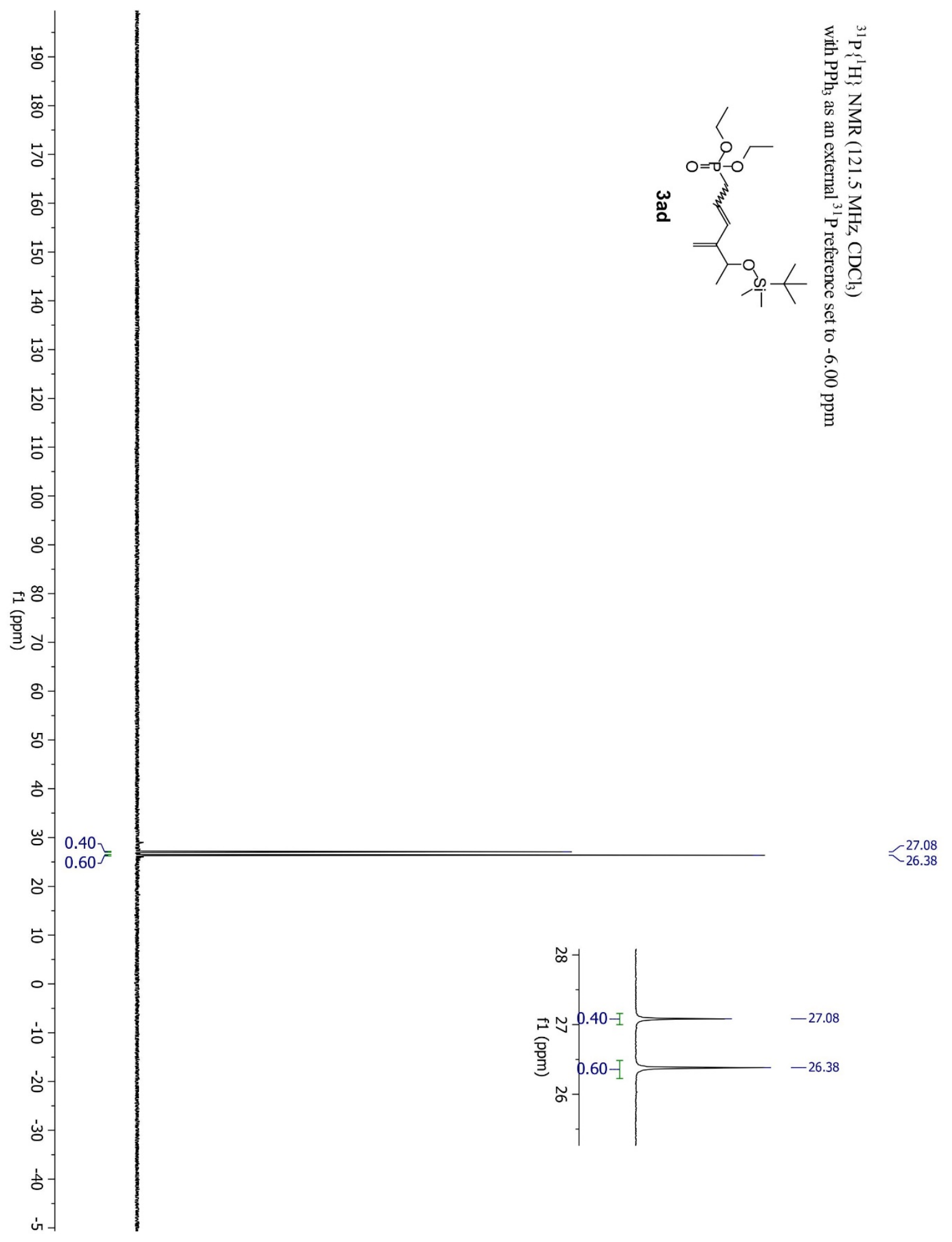




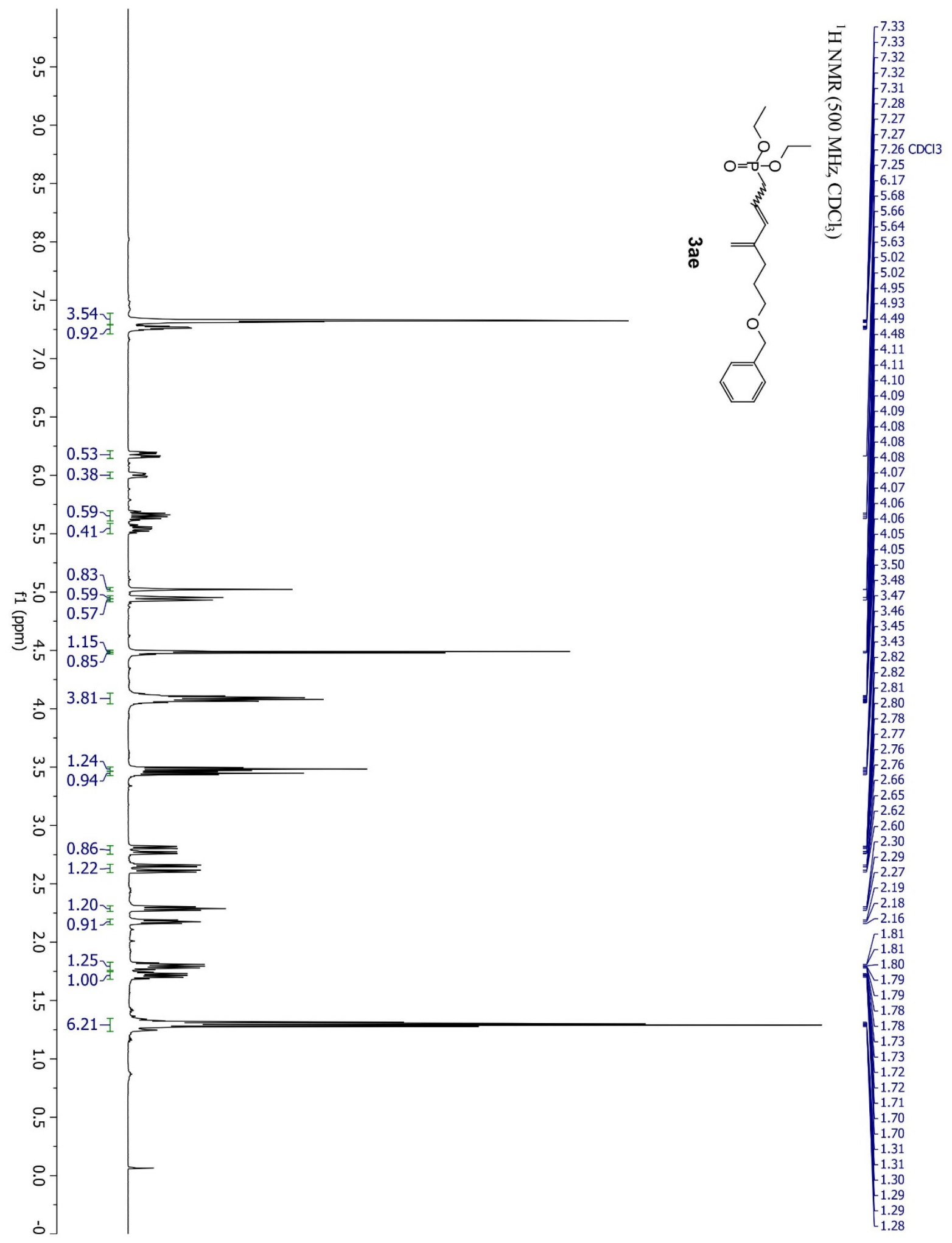




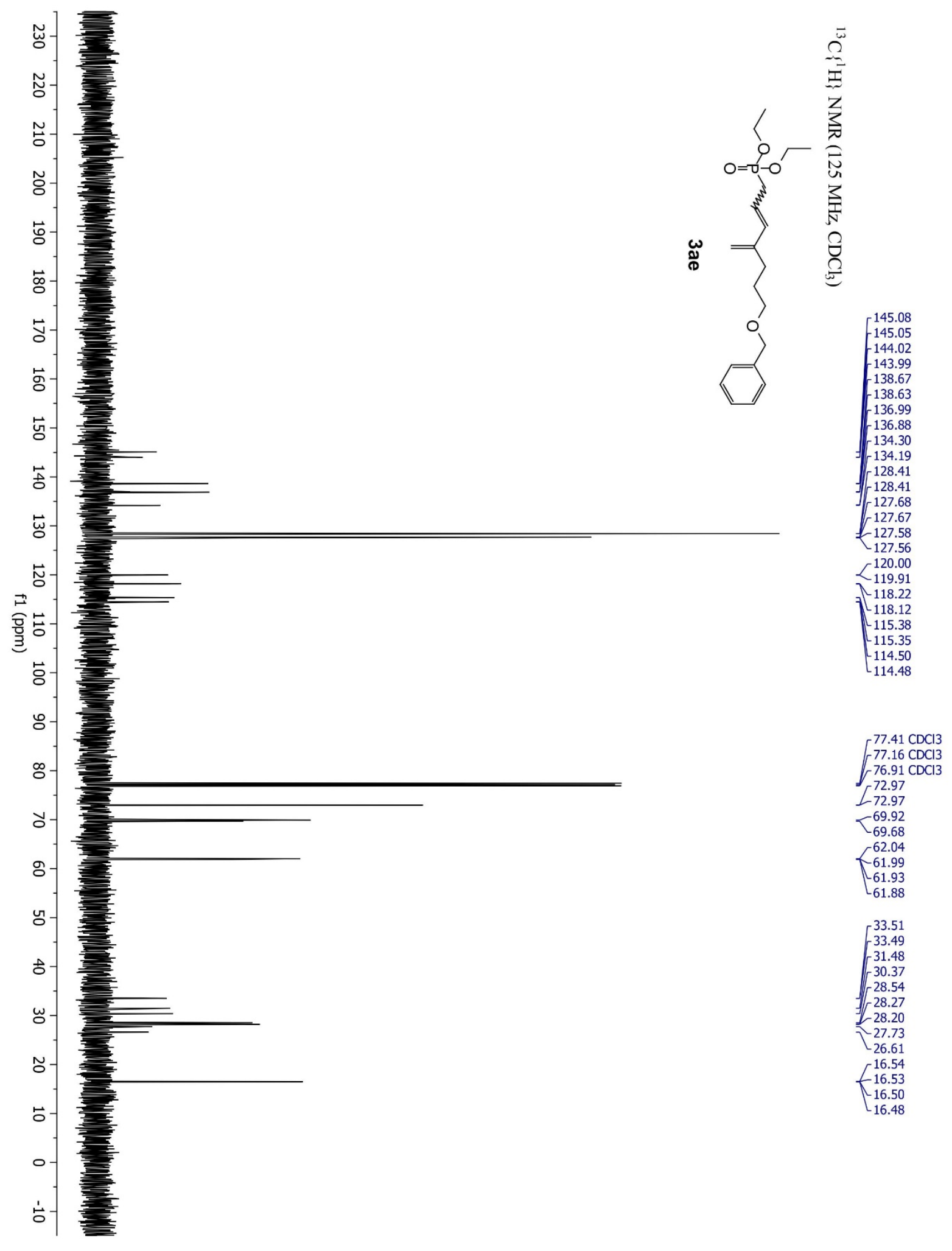




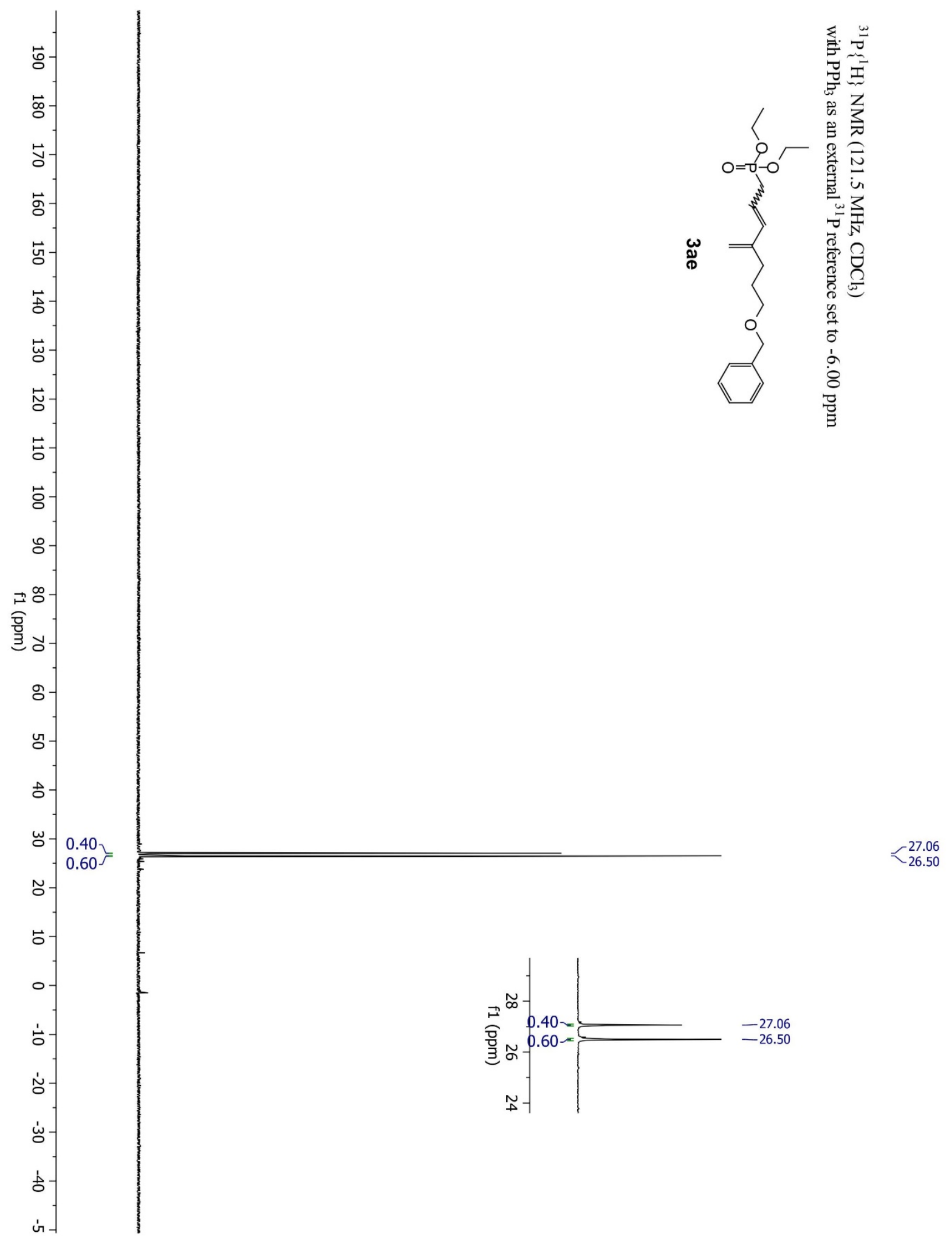




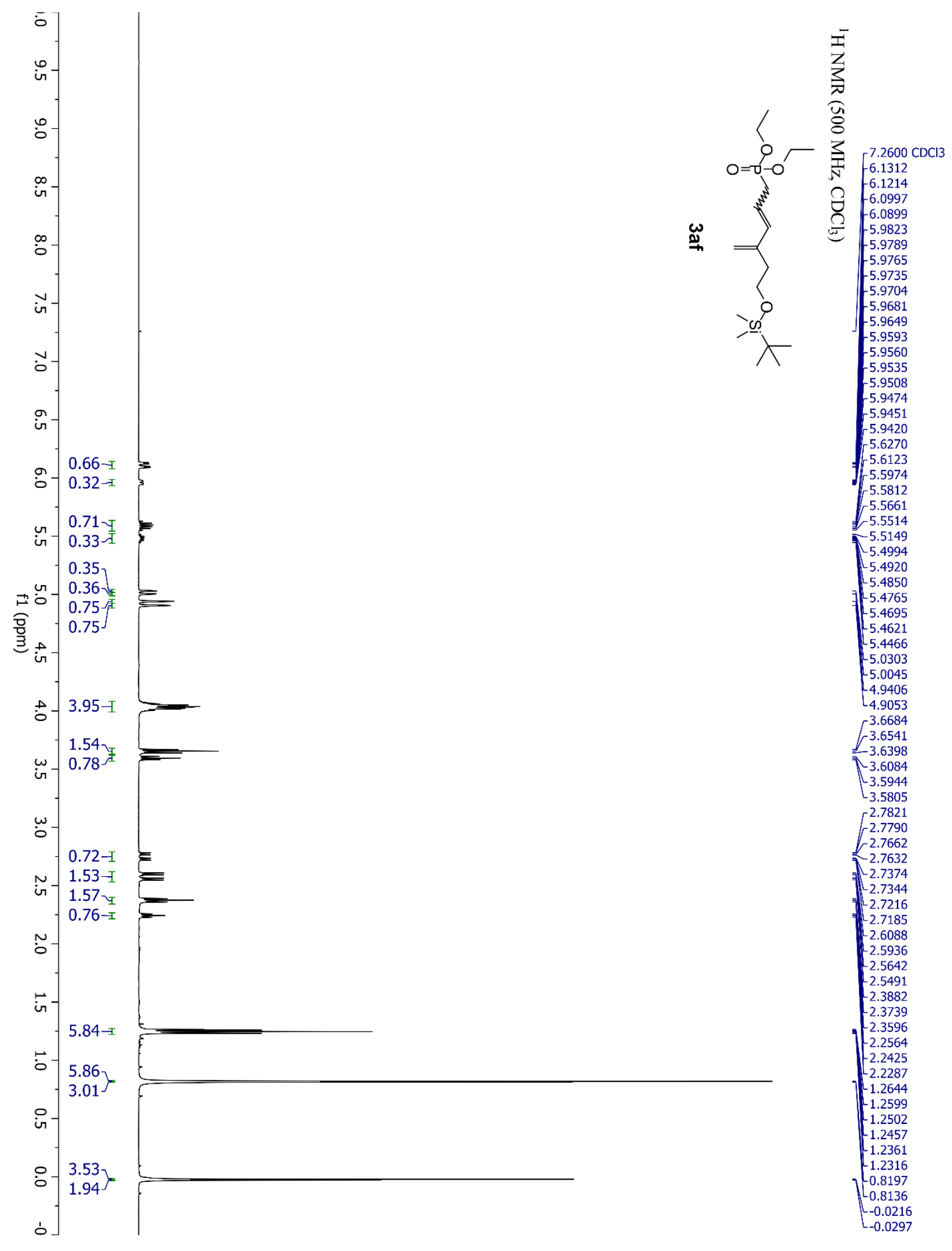



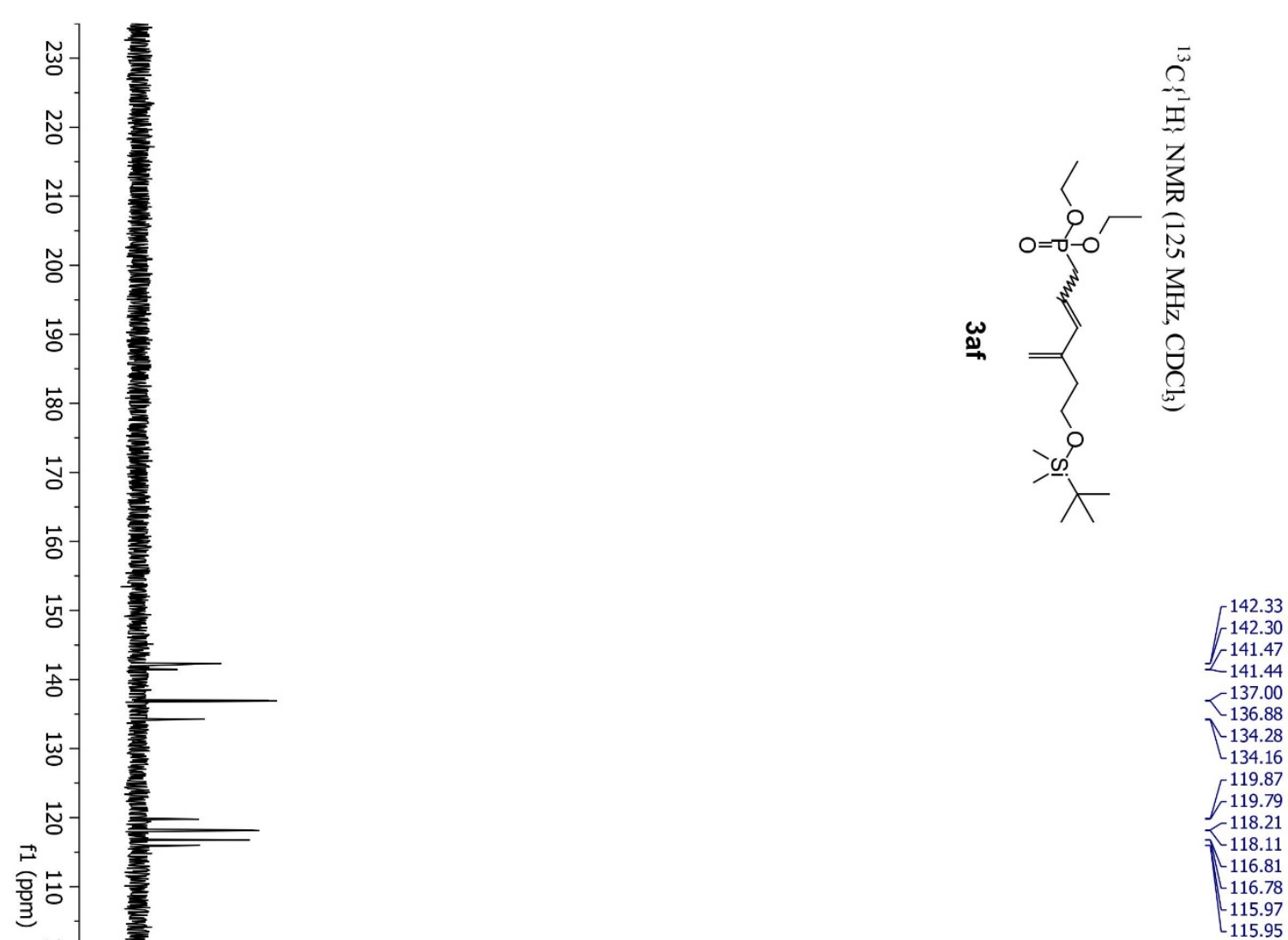

$77.42 \mathrm{CDCl} 3$ $-77.16 \mathrm{CDCl} 3$ $76.91 \mathrm{CDCl}^{3}$

62.02

$-61.96$

61.91
61.87

61.81

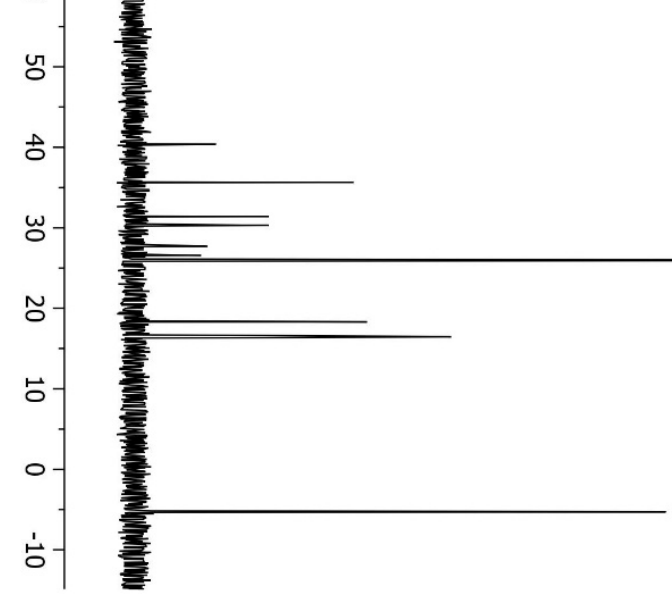

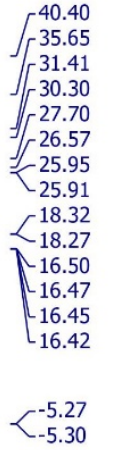




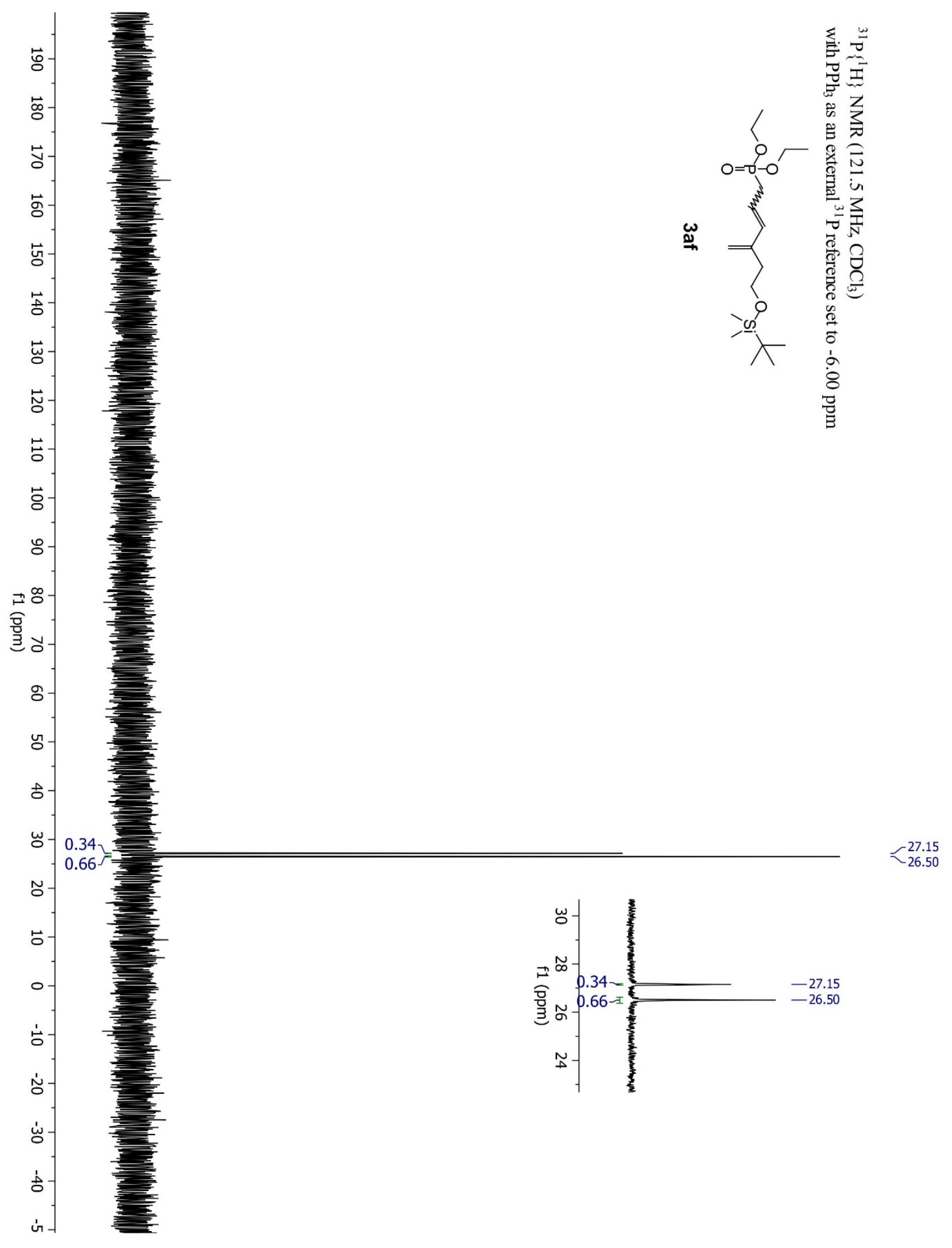




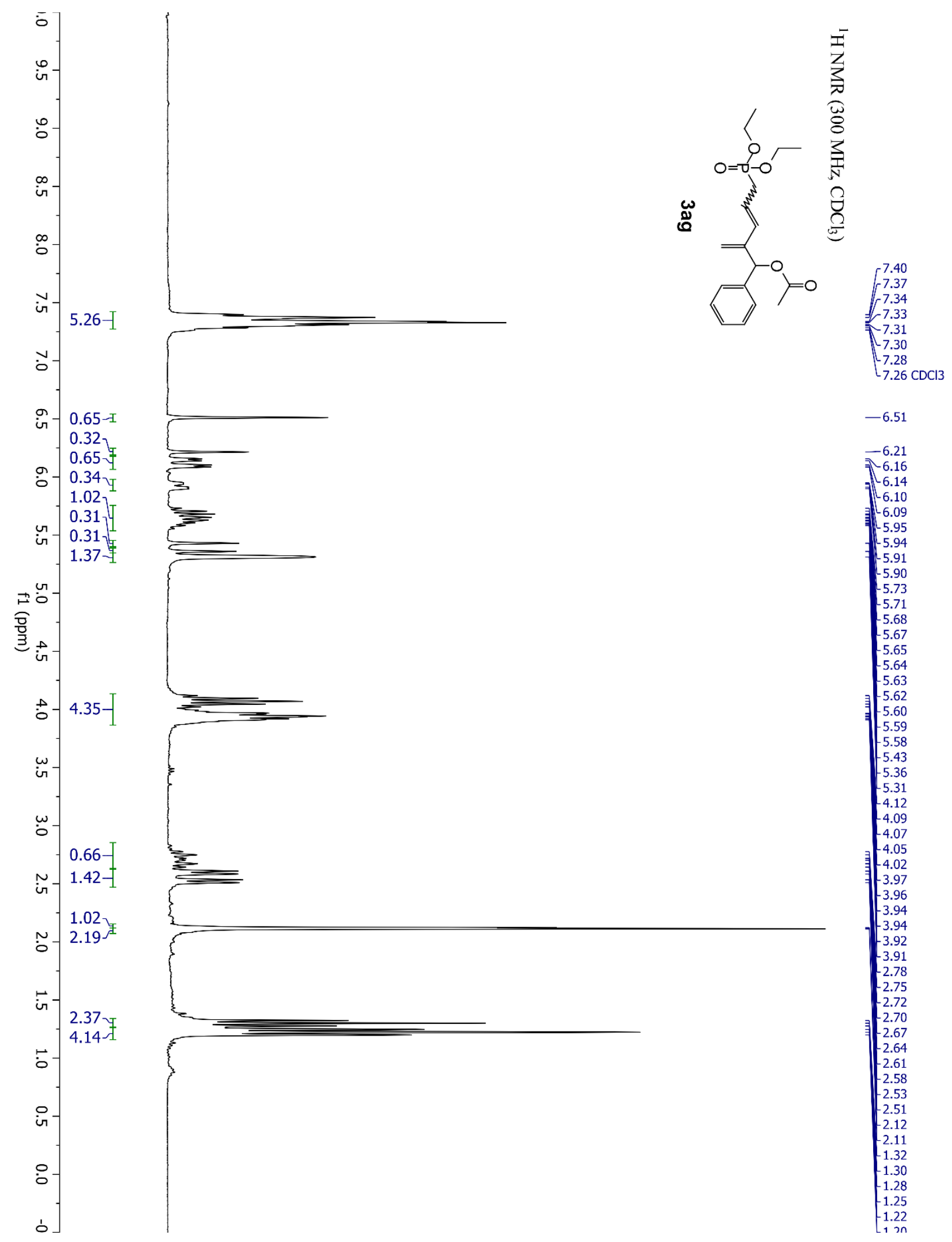



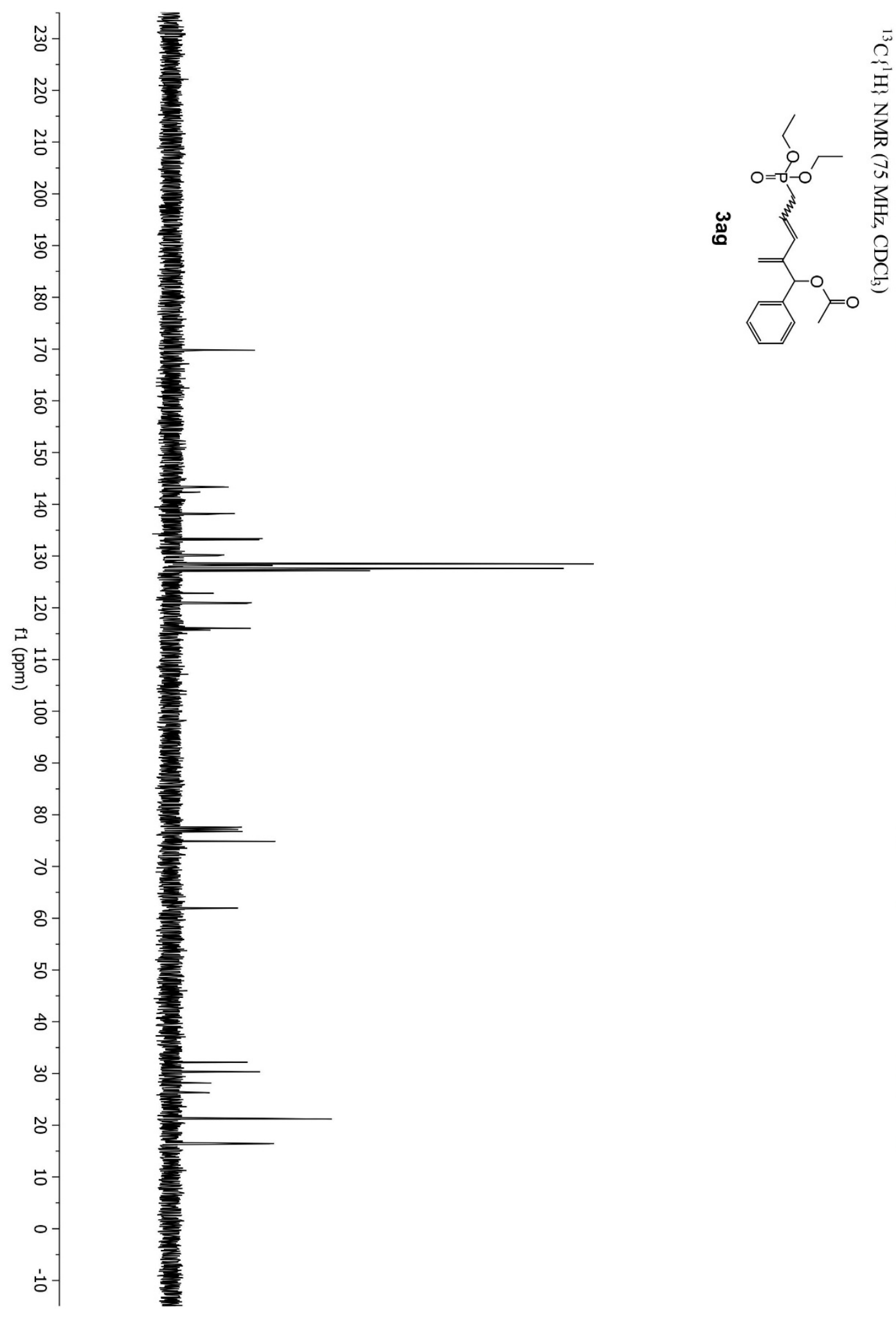

169.78
169.76 143.39

$-143.33$

$-142.37$

$-142.32$

138.22

$-138.05$

$-133.36$

133.16

130.24

130.05

128.51

128.46

$-128.28$

128.18

$-127.63$

127.15

122.80
122.66

122.66

$-120.98$

120.83

$-116.08$

116.03

115.74
-115.70

$77.59 \mathrm{CDCl} 3$

77.47
-77.45

$77.16 \mathrm{CDCl}$

76.74 CDCl3

74.87

62.06

$-62.00$

$-61.97$

61.96

61.91

61.86

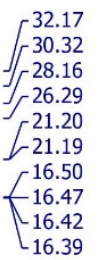




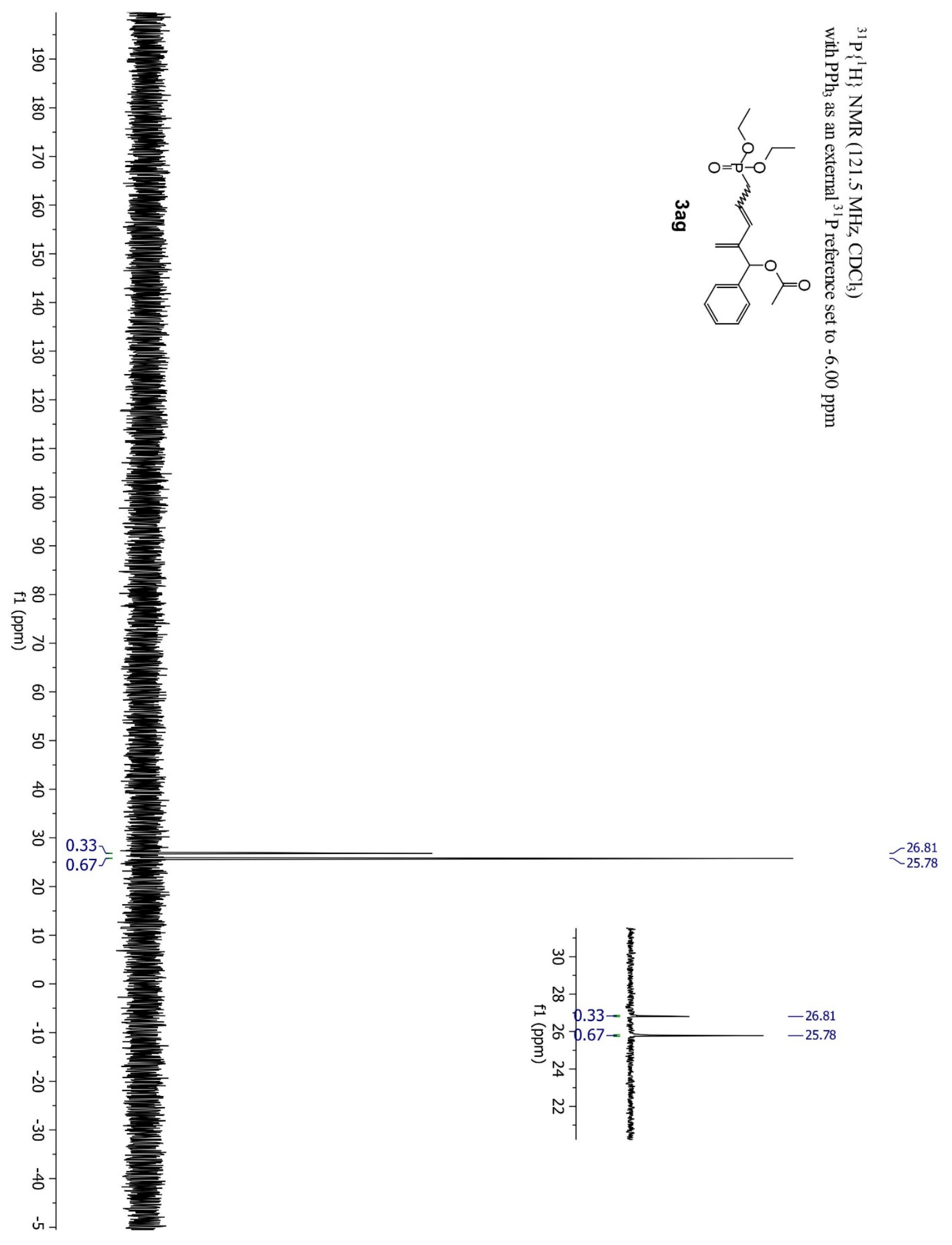




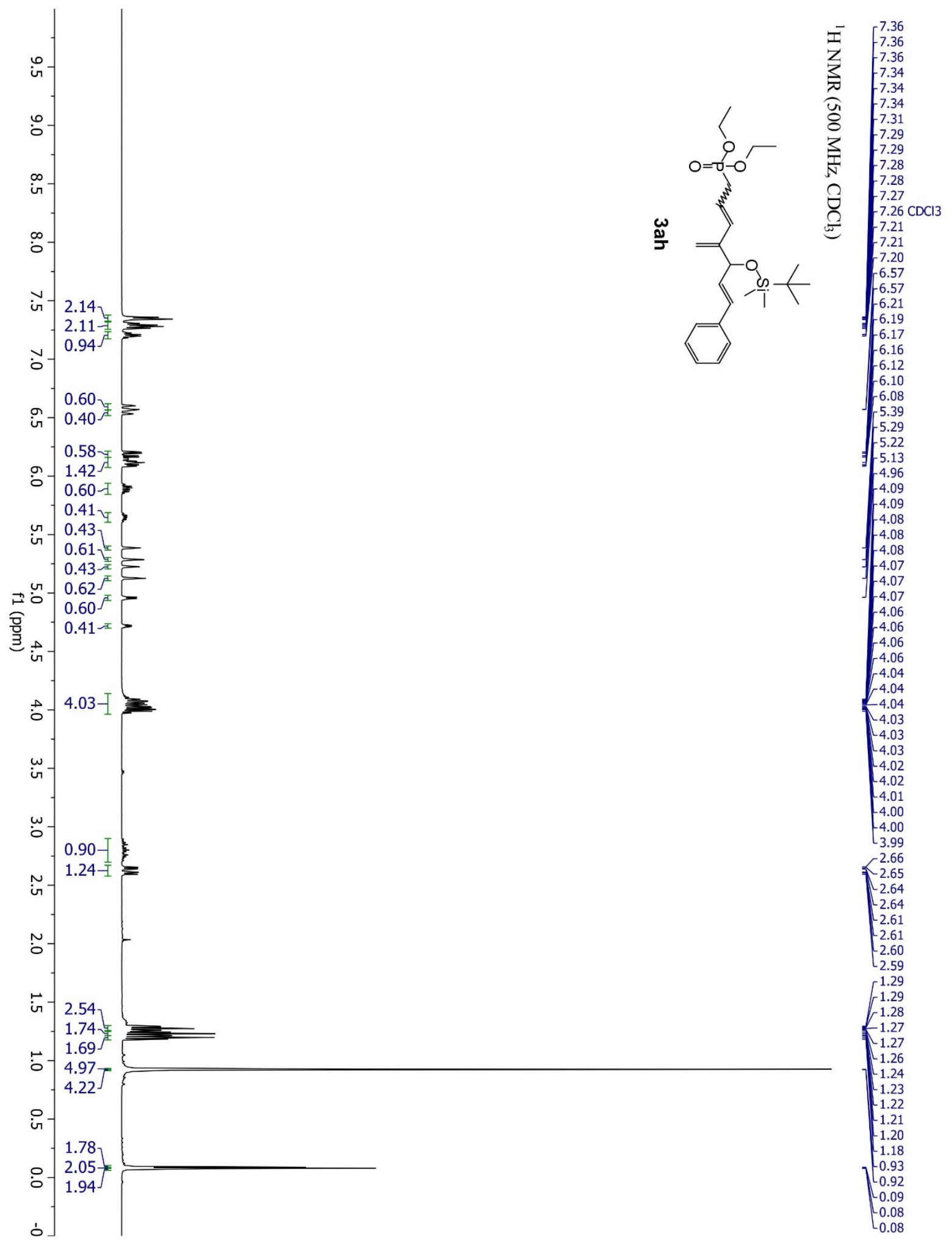




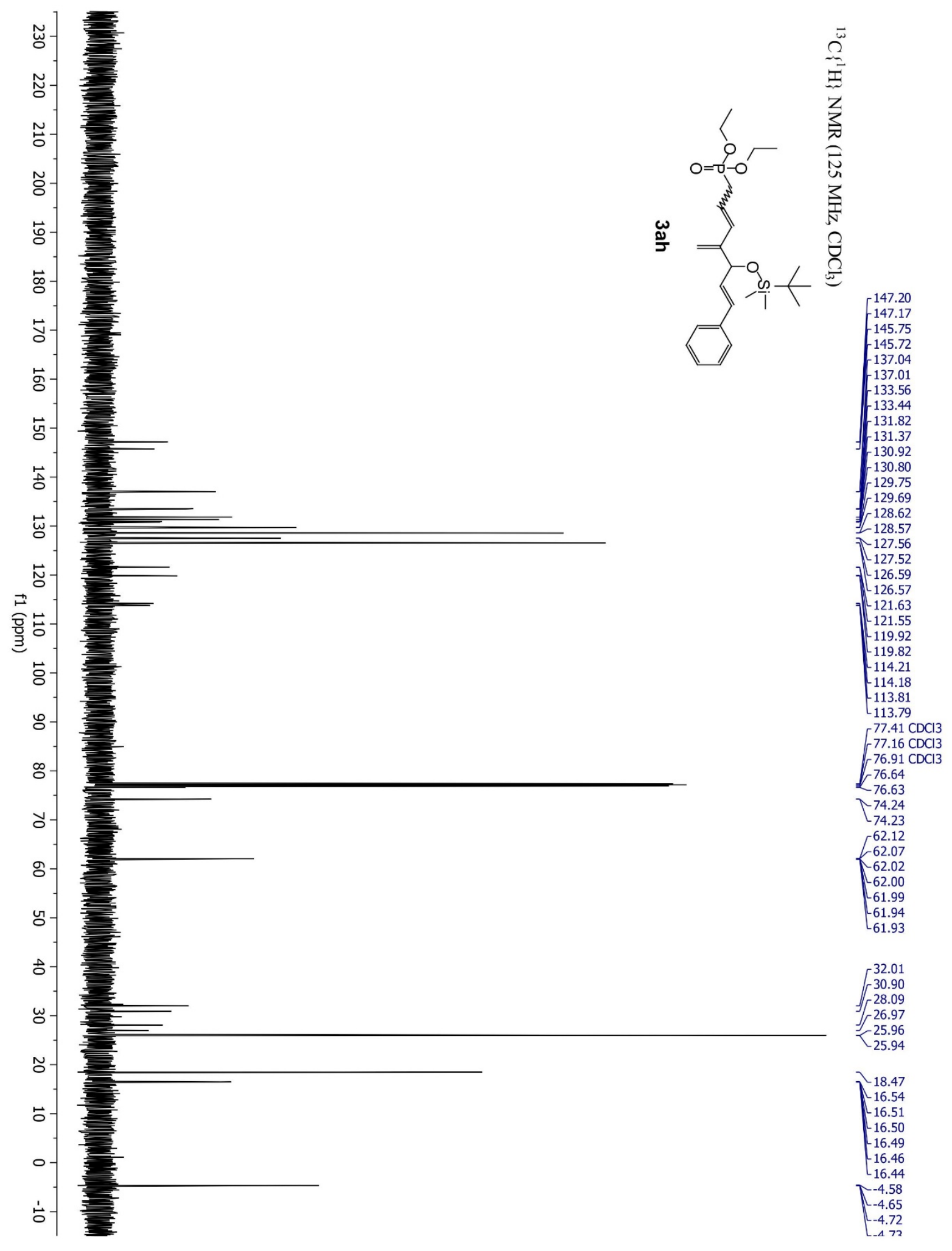




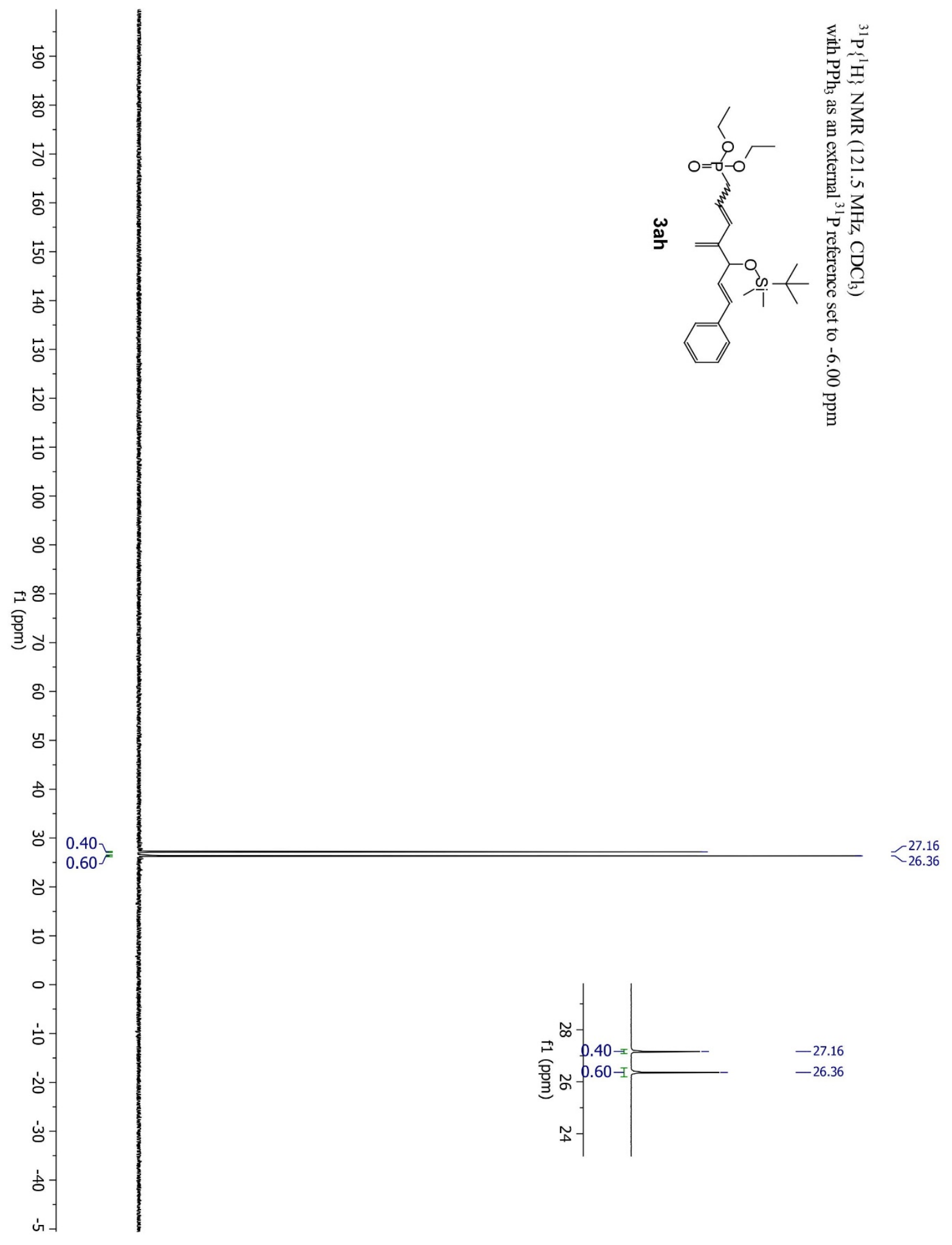




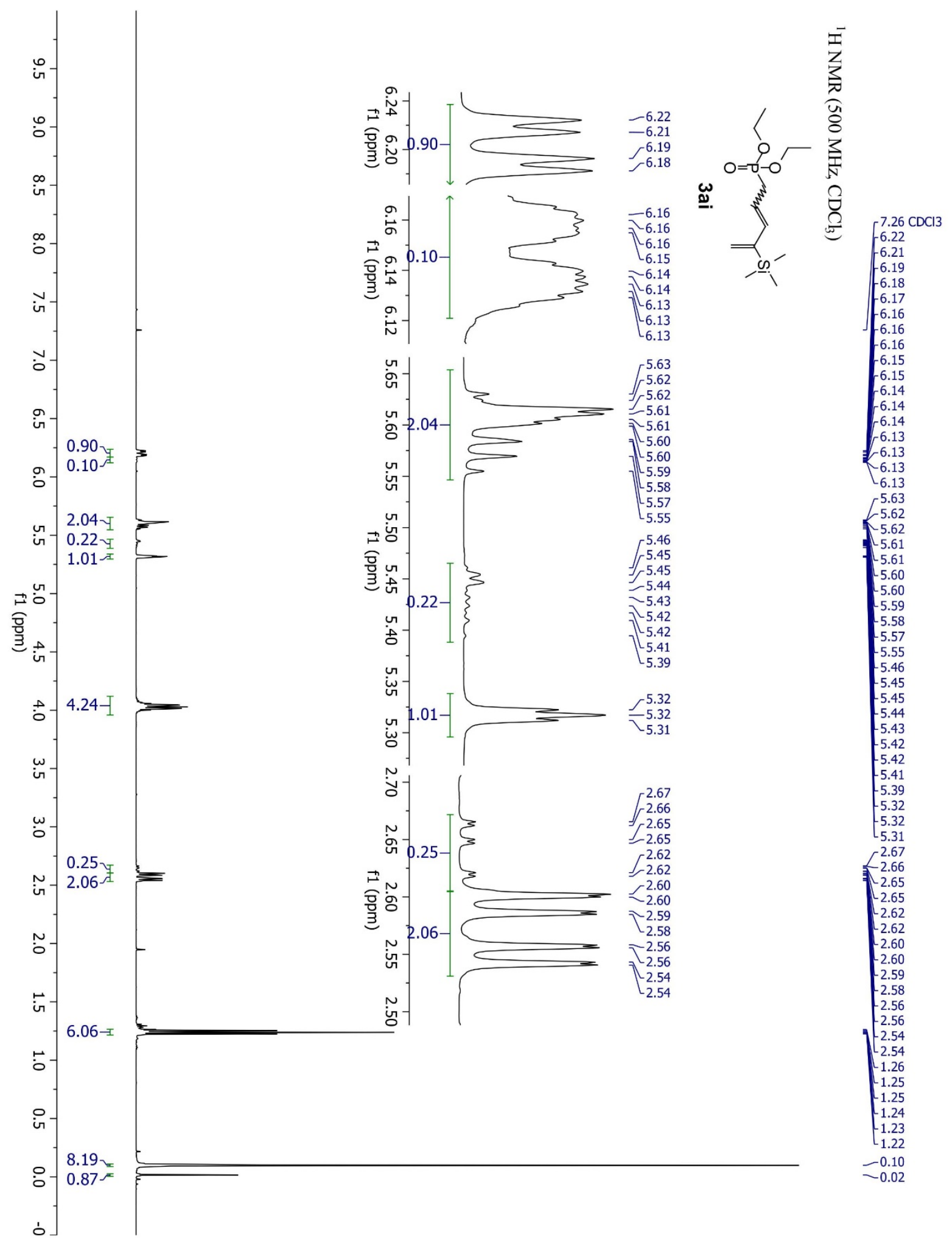




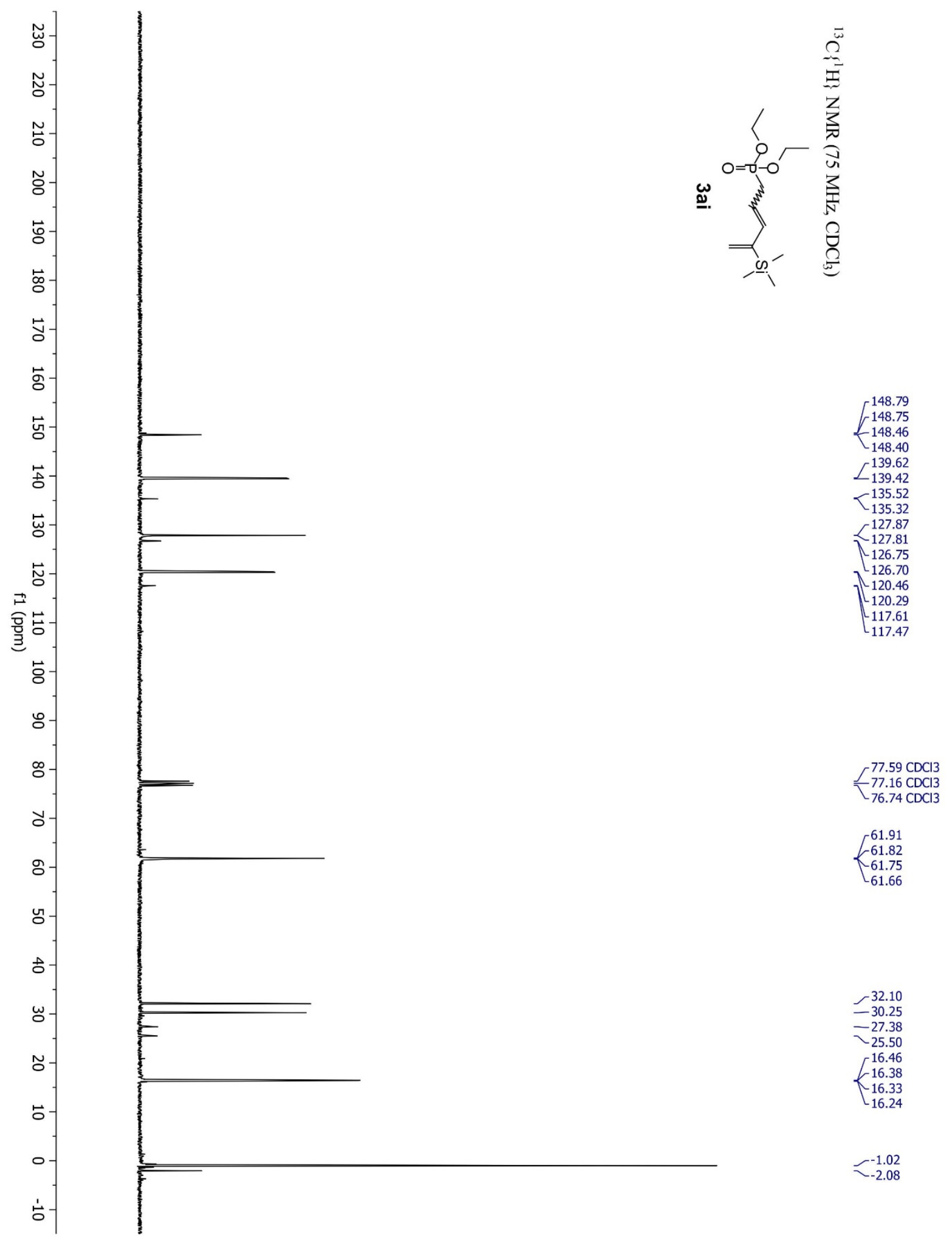




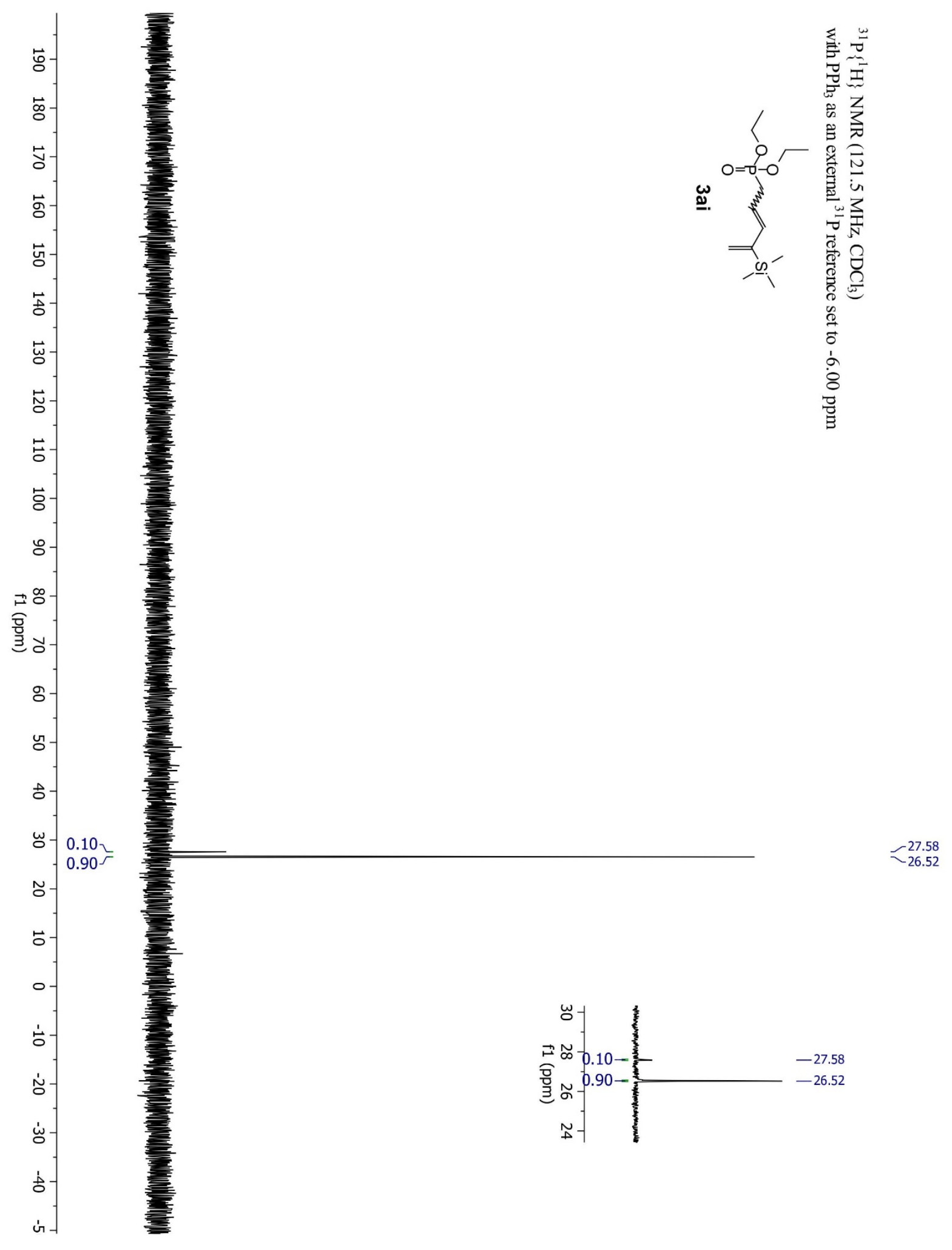




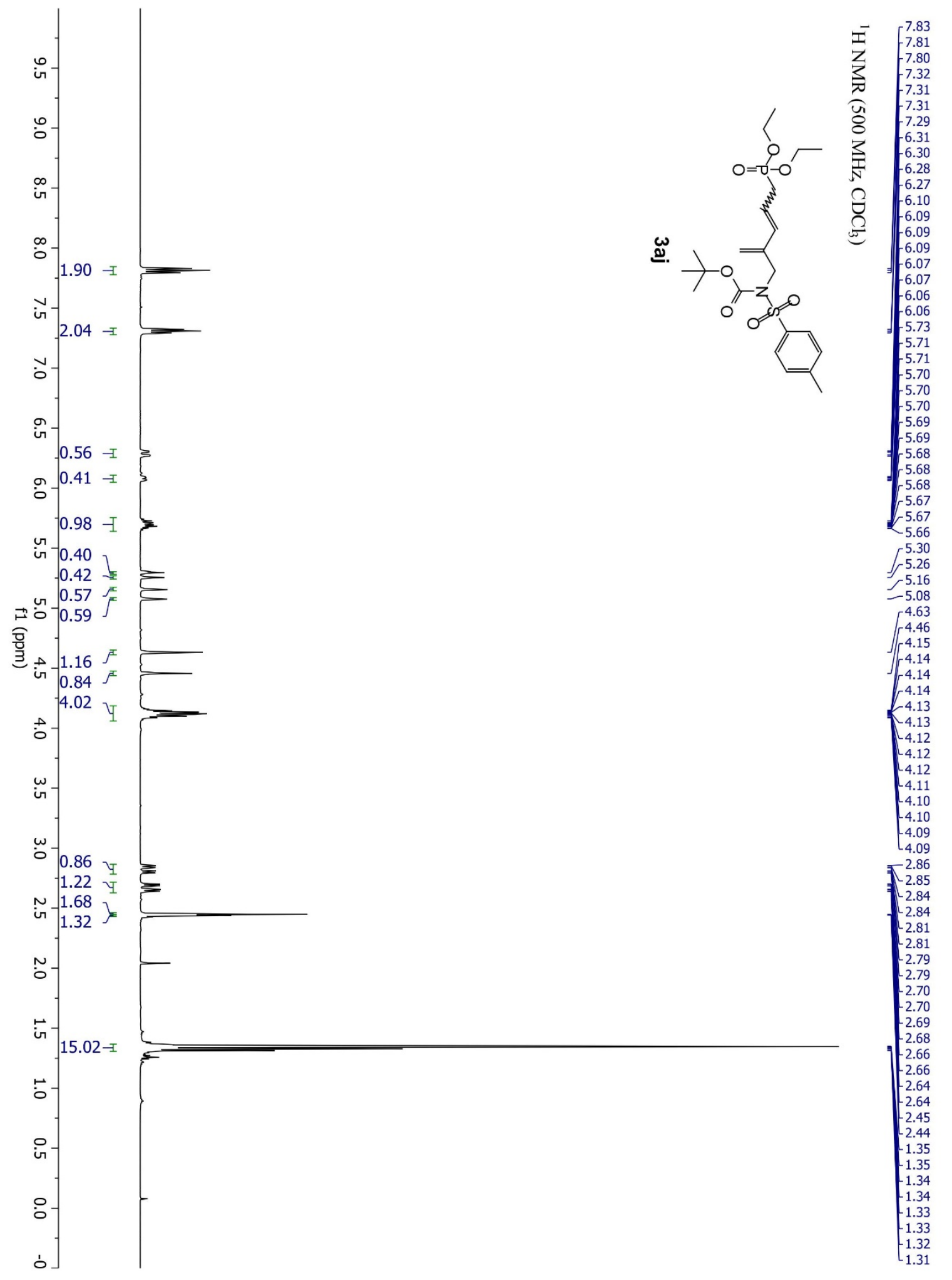



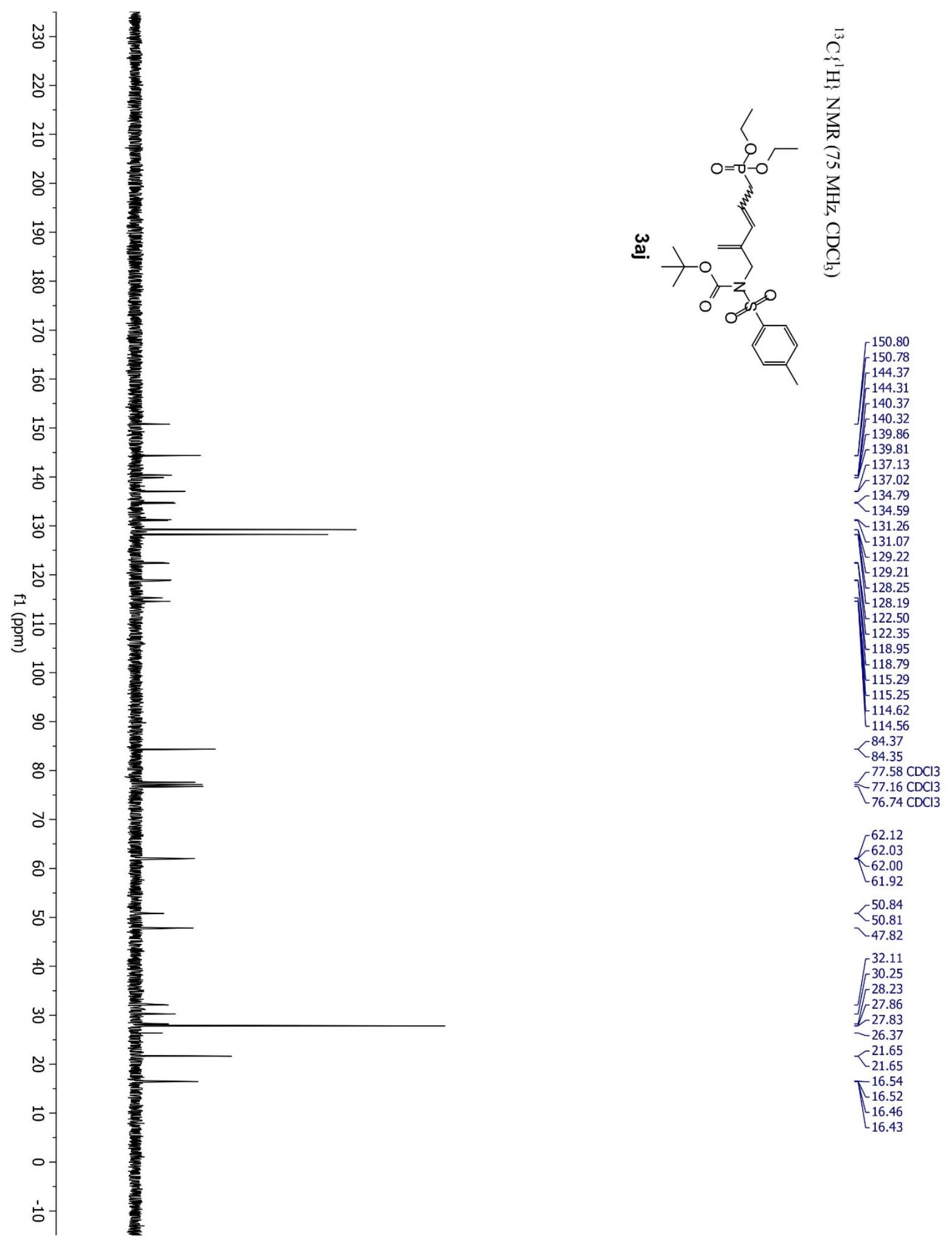


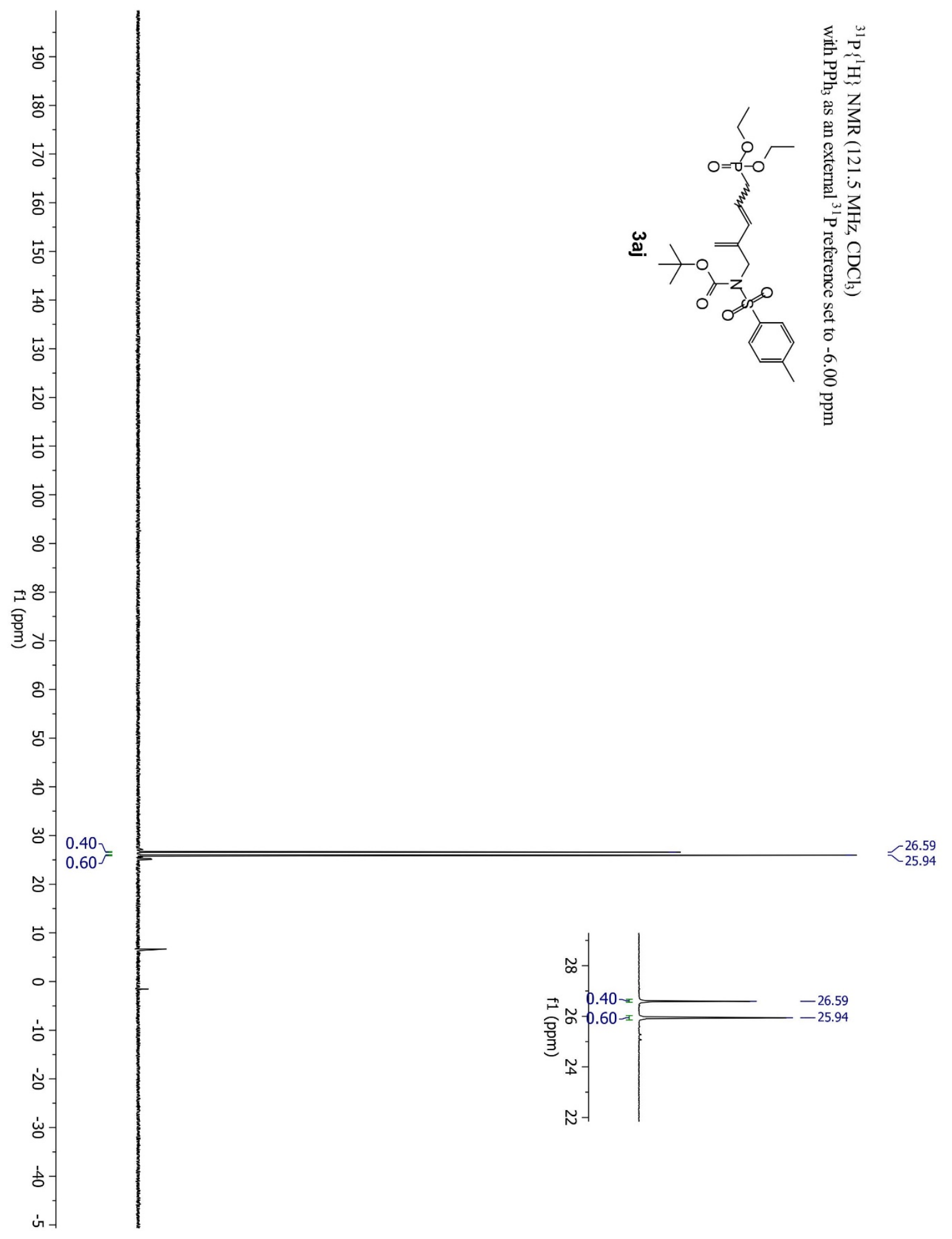




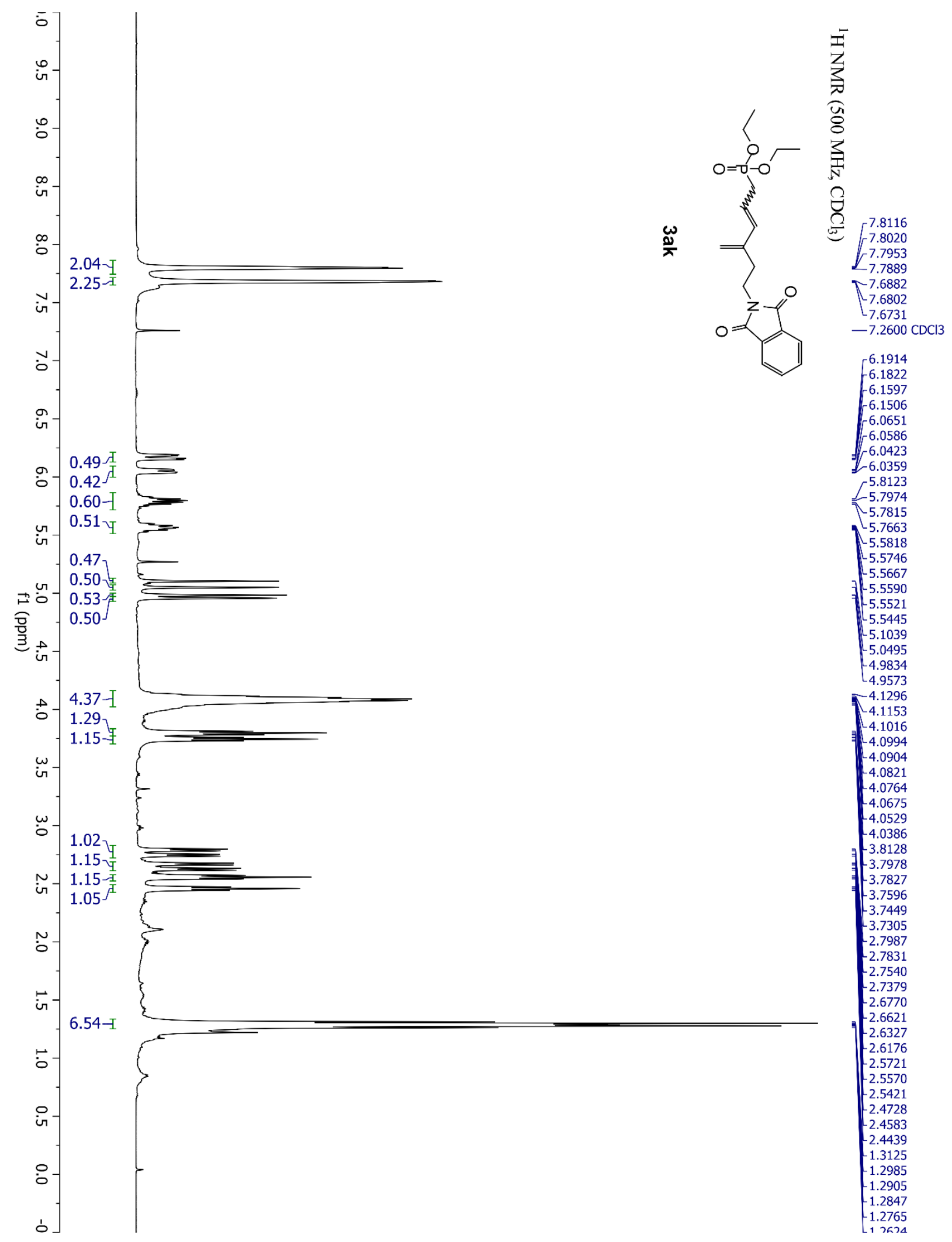



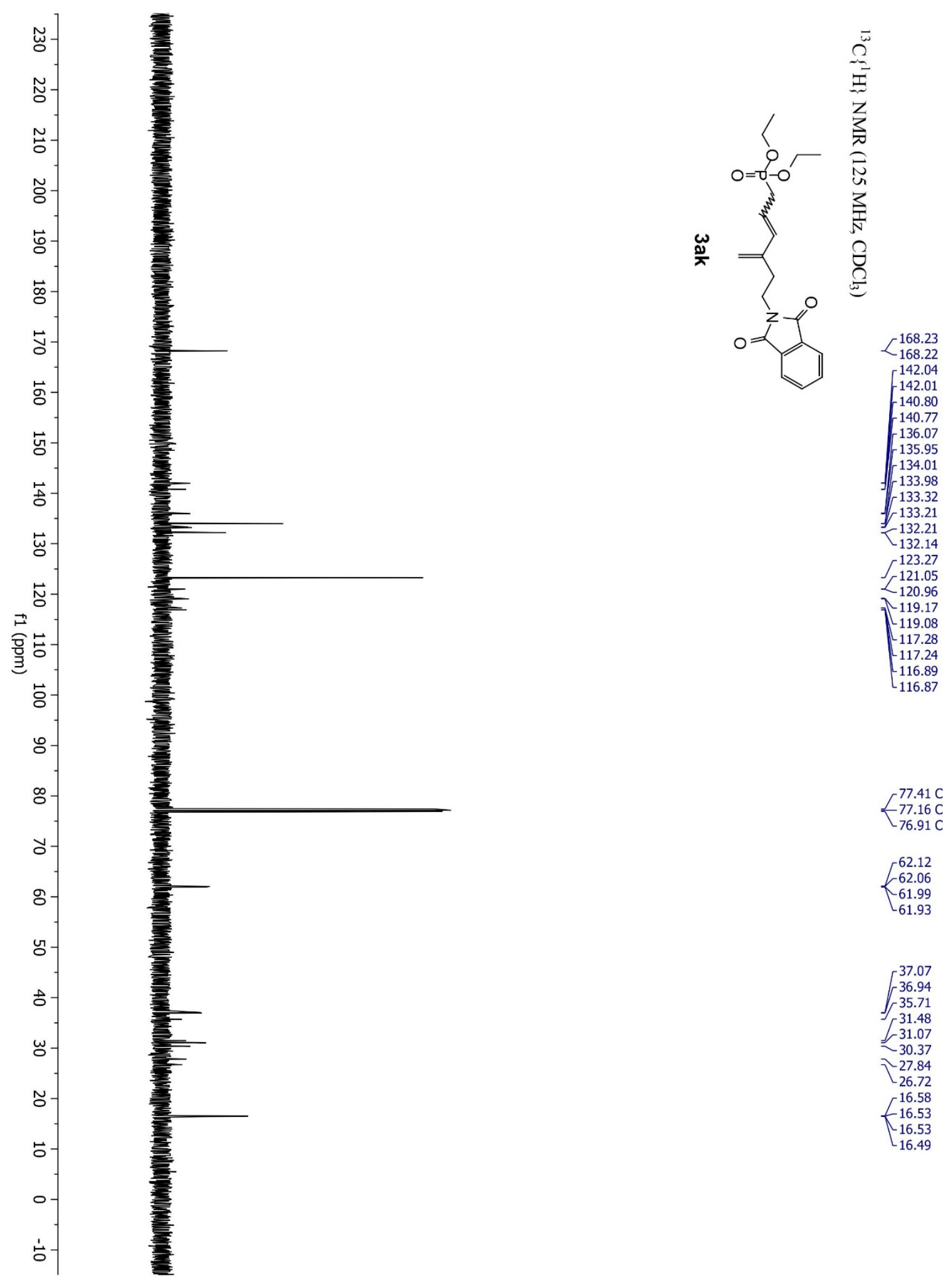

$77.41 \mathrm{CDCl} 3$ $\left\{\begin{array}{r}77.16 \mathrm{CDCl} 3 \\ 76.91 \mathrm{CDCl} 3\end{array}\right.$

62.12
-62.06

$K_{61.99}^{62.06}$

61.93

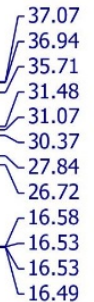




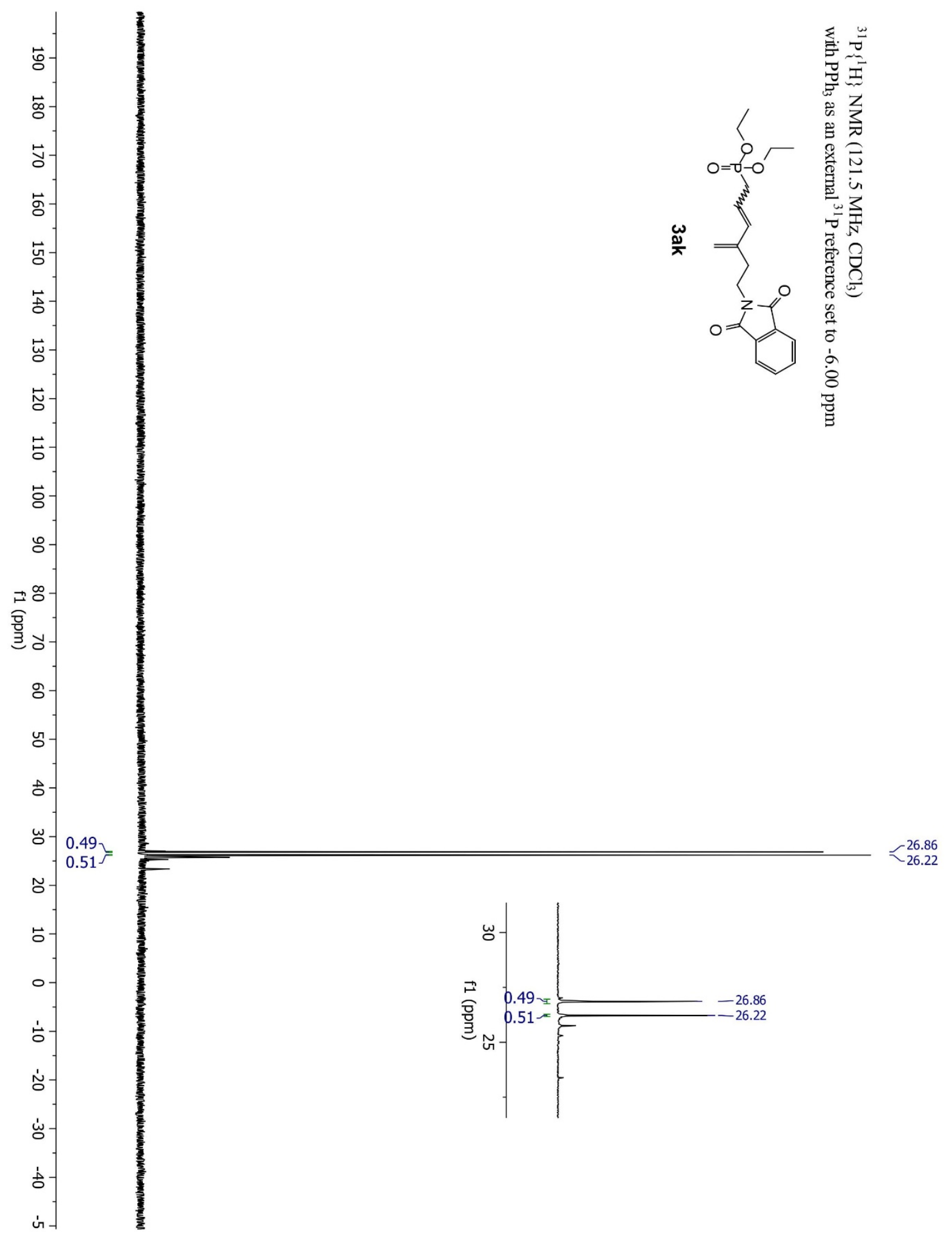




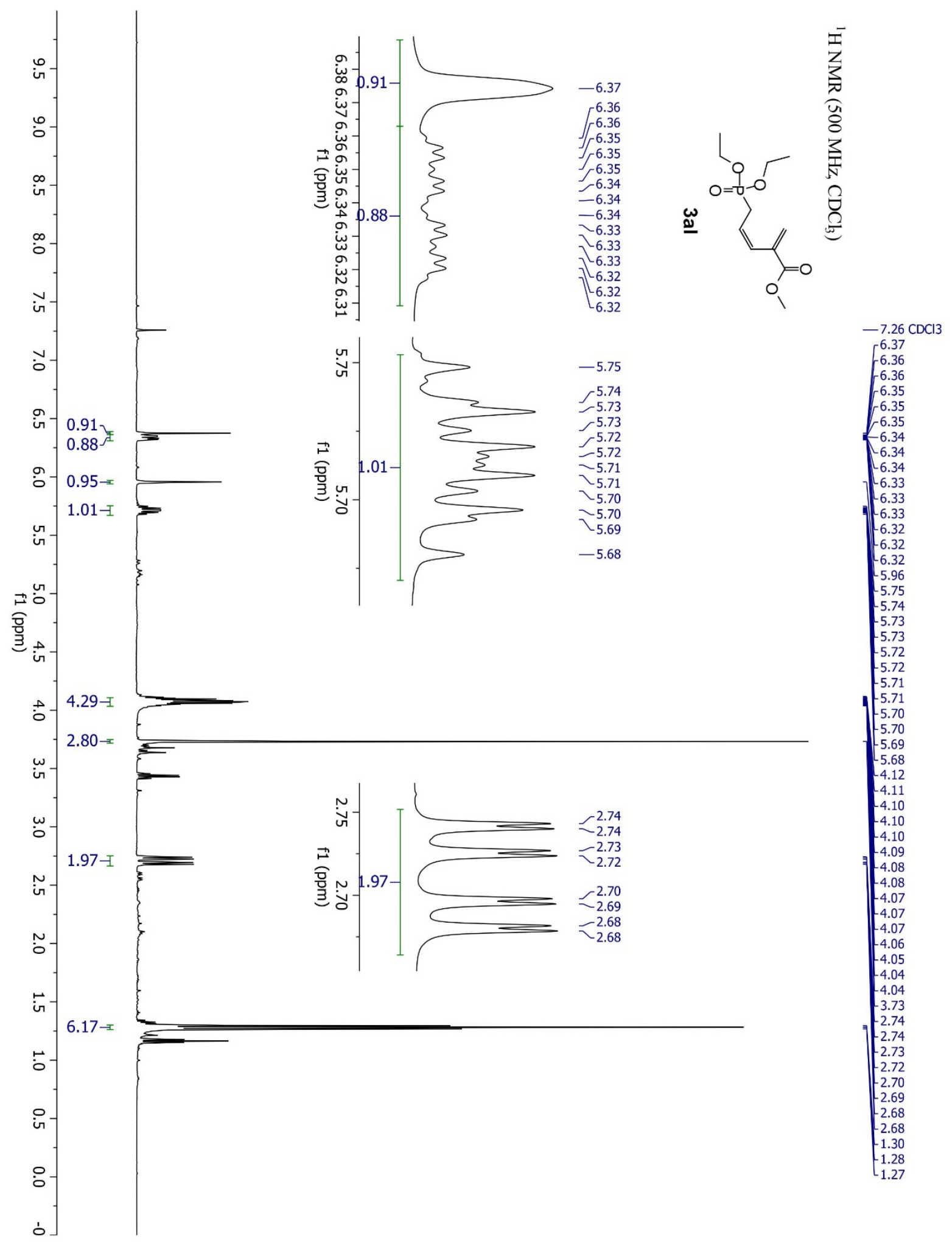



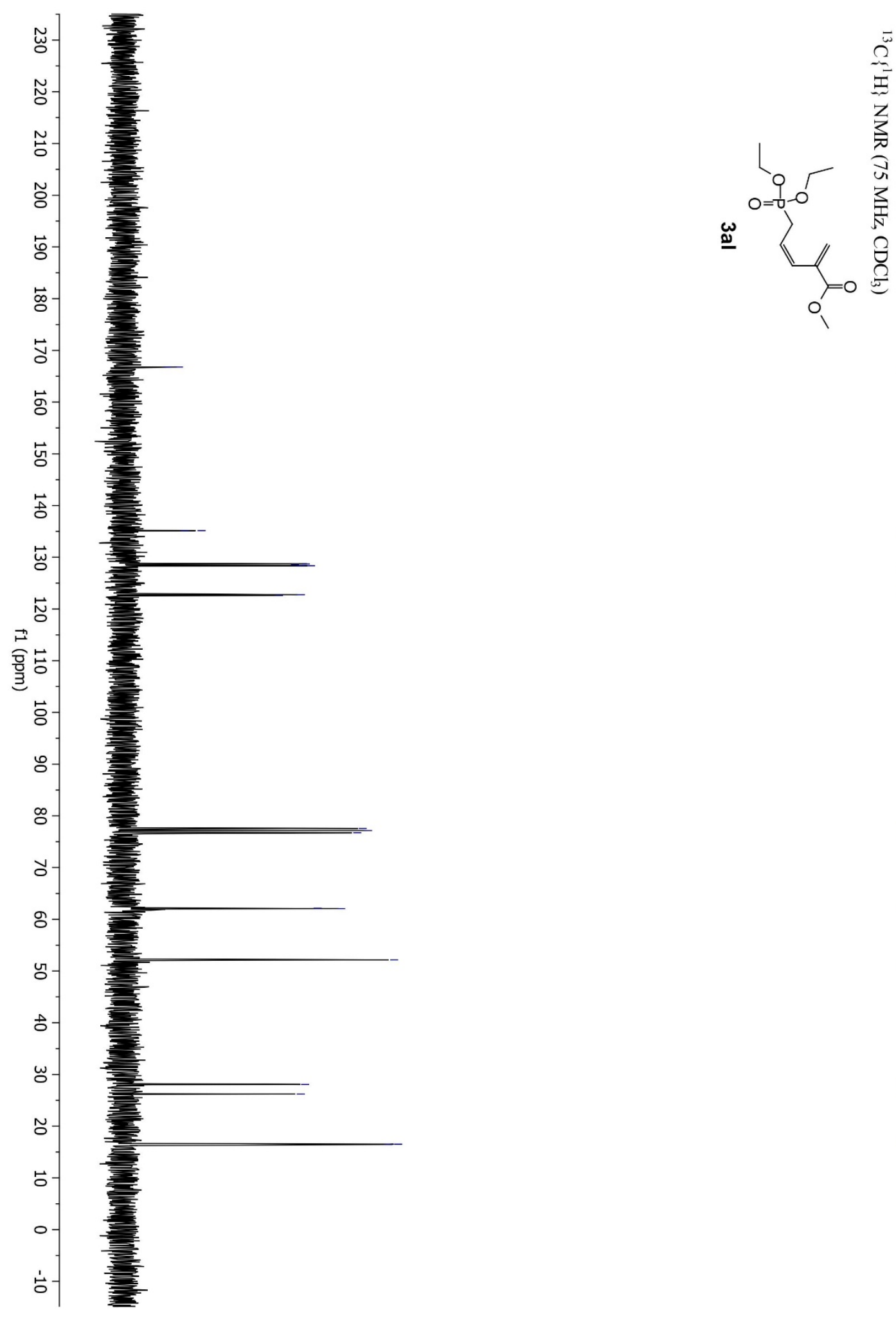

$<\begin{array}{r}166.80 \\ 166.78\end{array}$

$<_{135.09}^{135.14}$ 128.71 $-128.52$ $-128.36$

$-128.33$

122.74

122.74
-122.60

$\int_{77.16 \mathrm{CDCl} 3}^{77.58 \mathrm{CDCl}}$

$-77.16 \mathrm{CDCl} 3$

$<\begin{array}{r}62.14 \\ 62.05\end{array}$

$-52.17$

$-28.08$

$\sim 26.21$

$<_{16.44}^{16.52}$ 

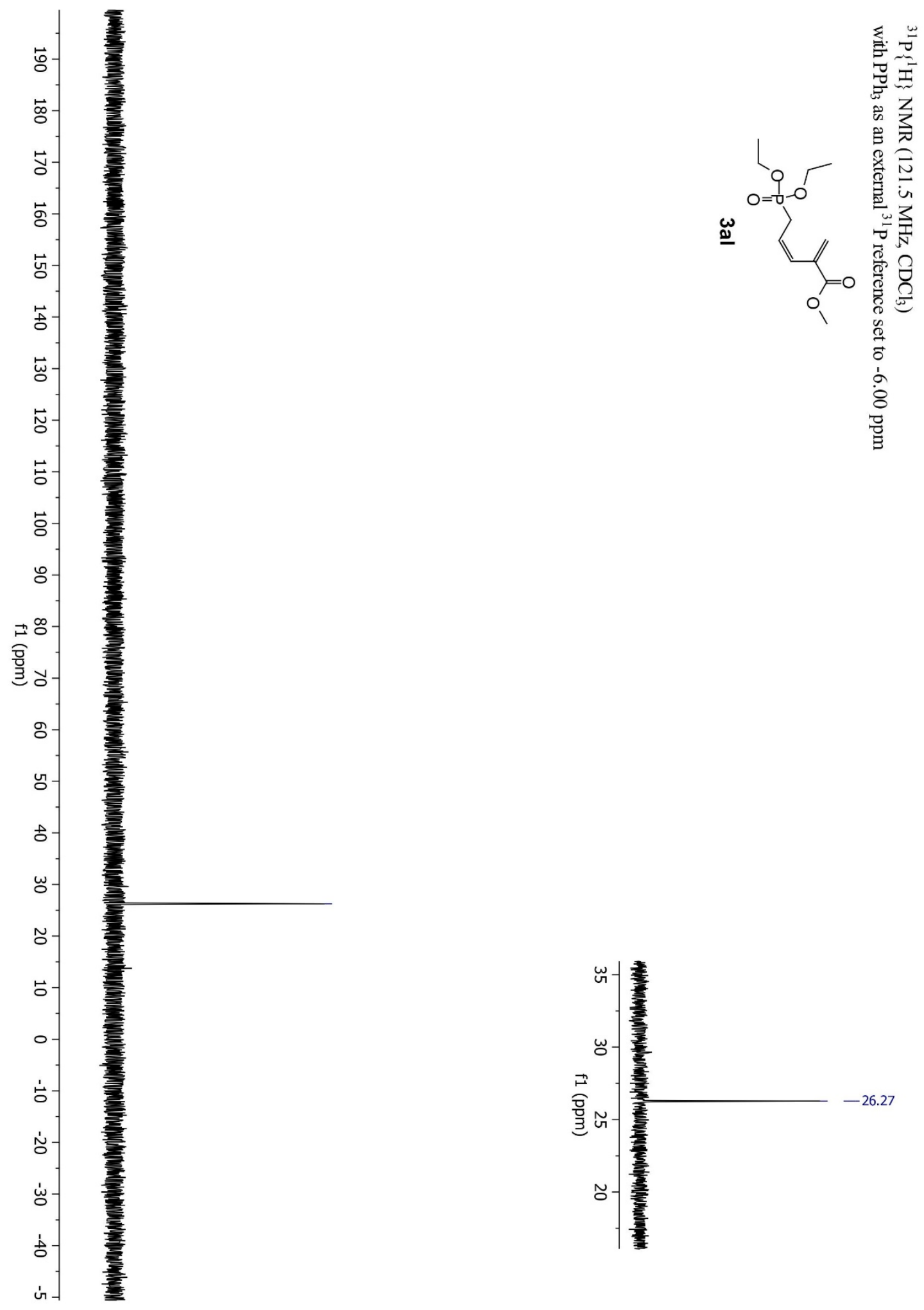

$-26.27$

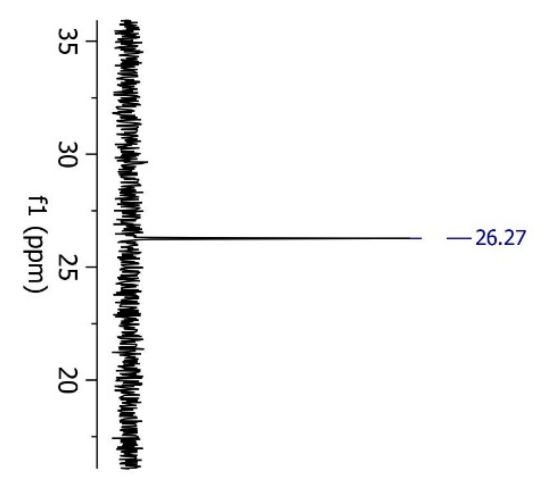




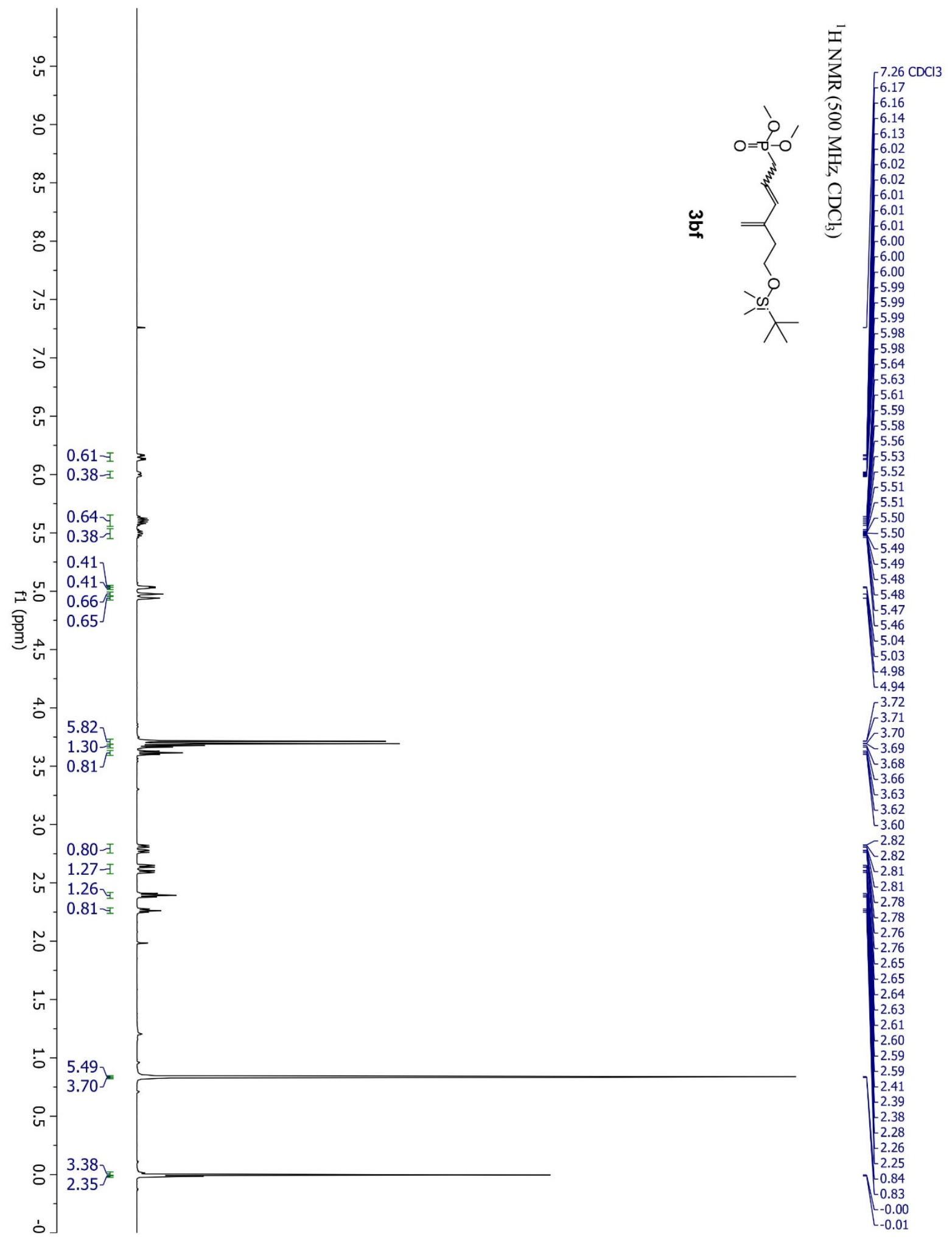



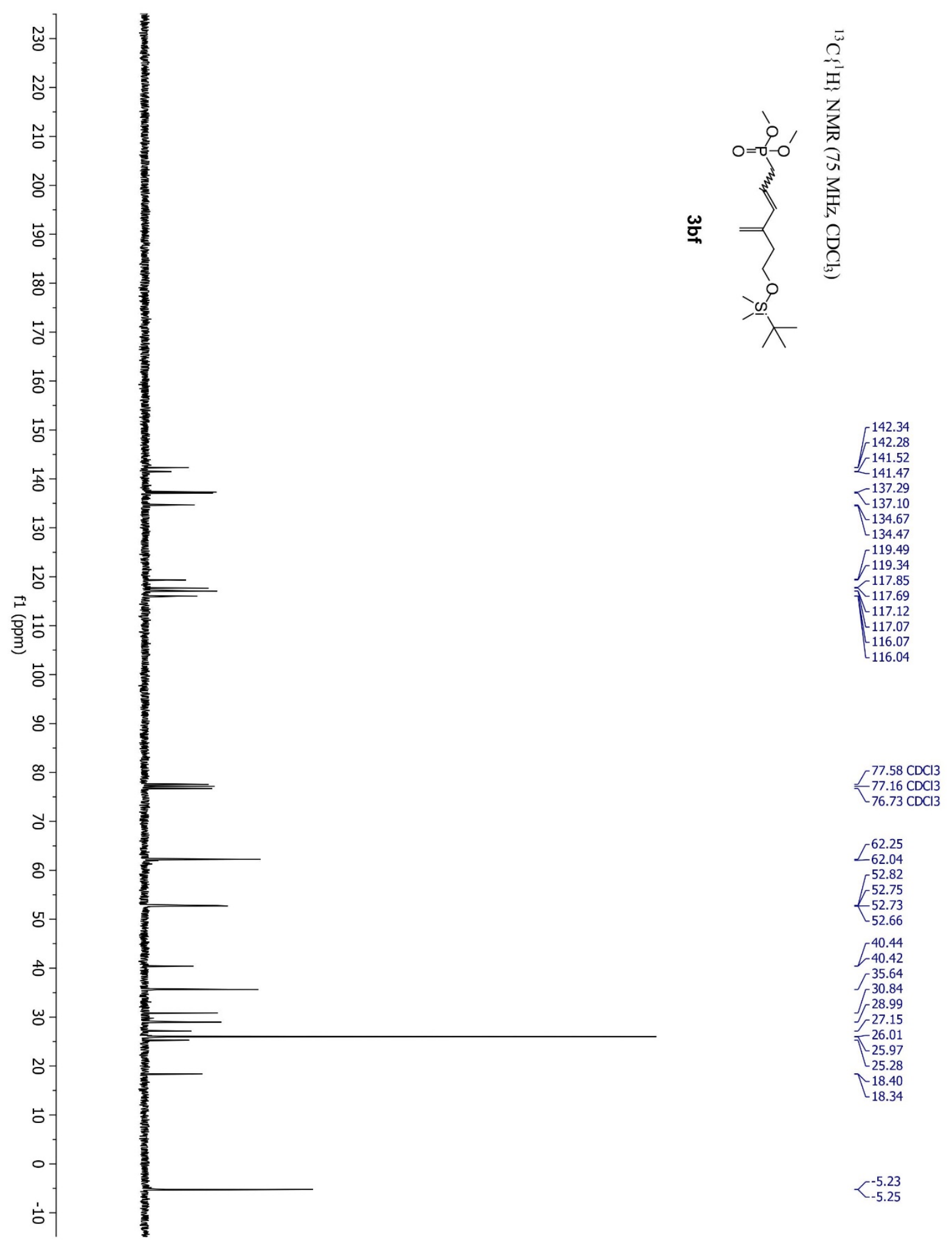


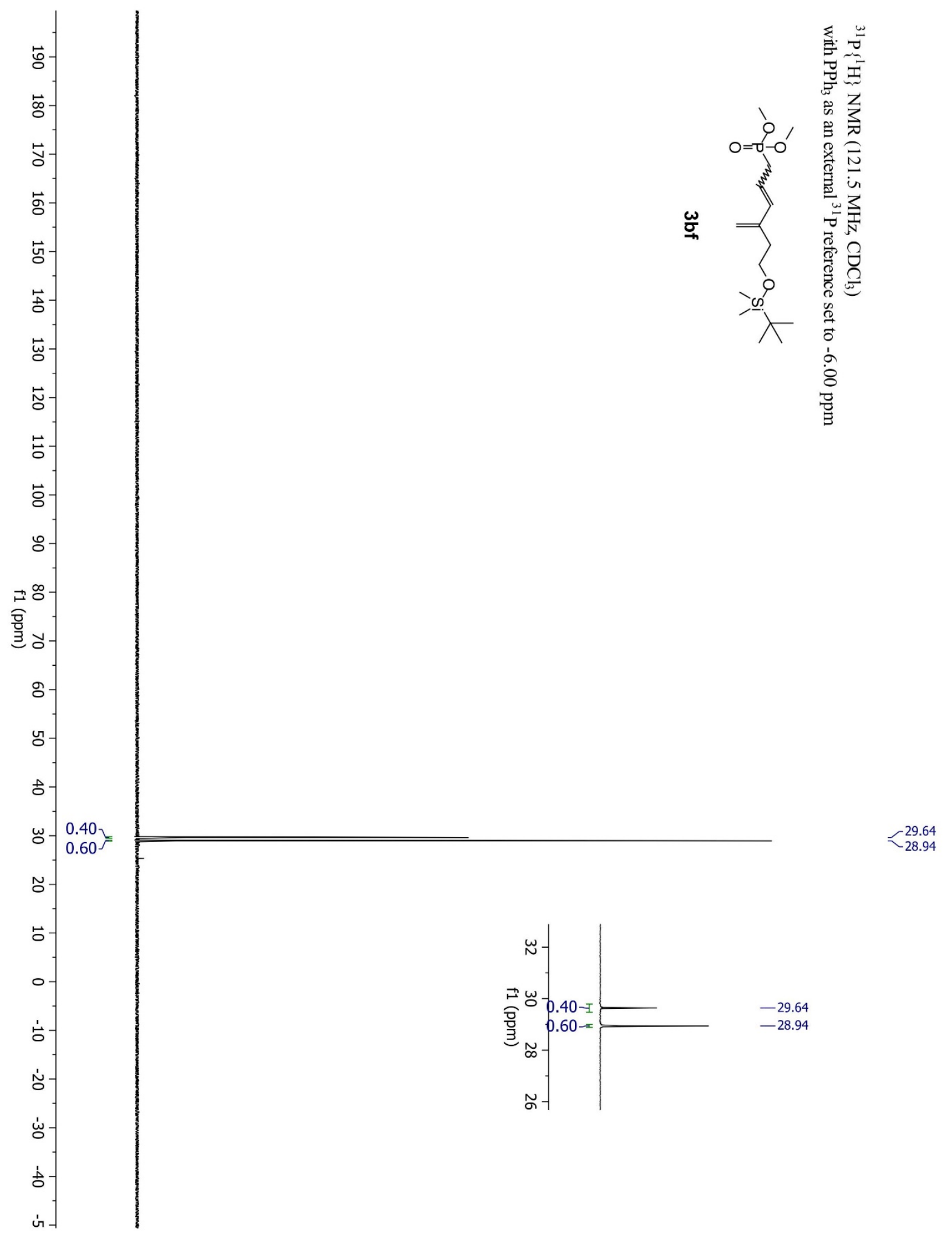




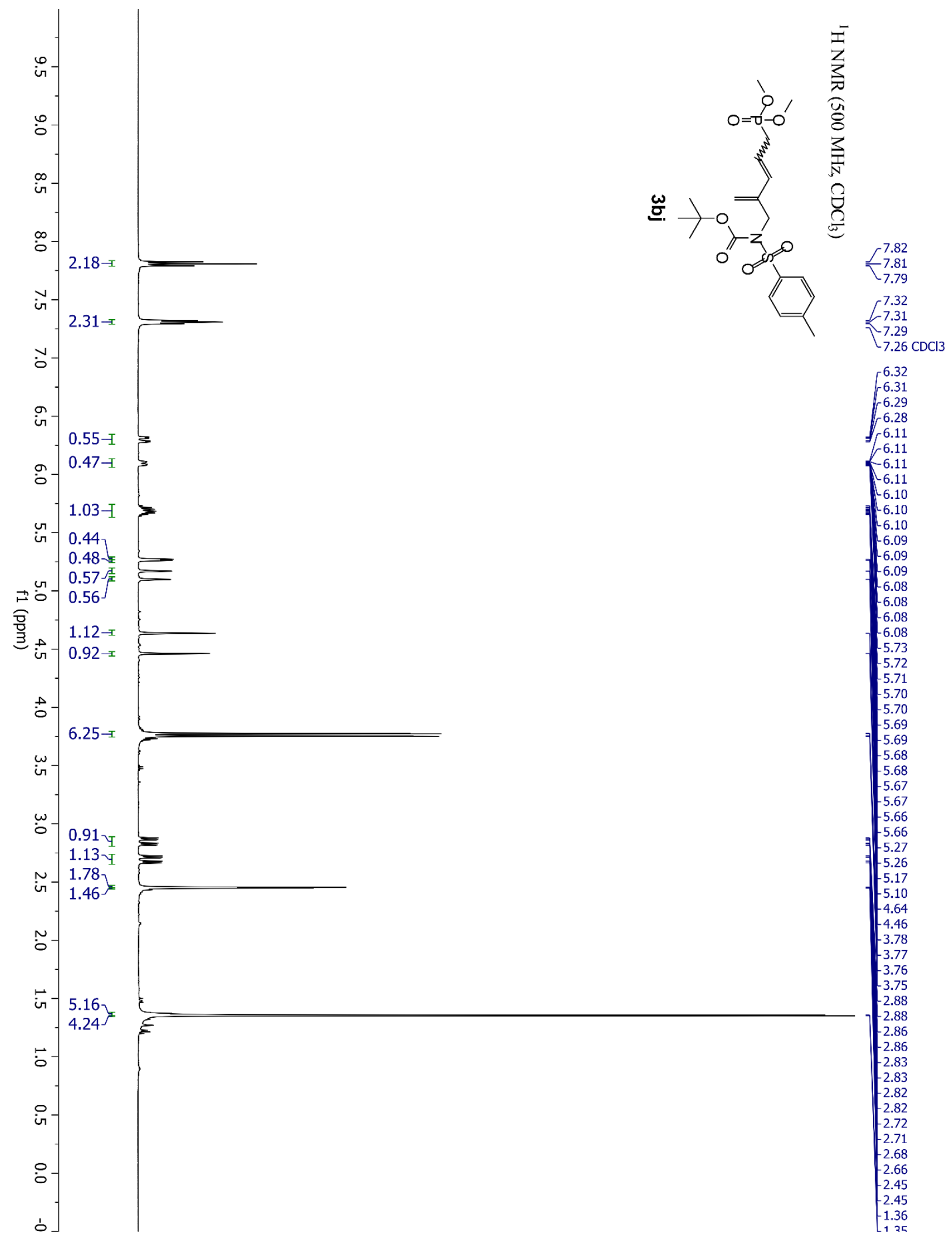




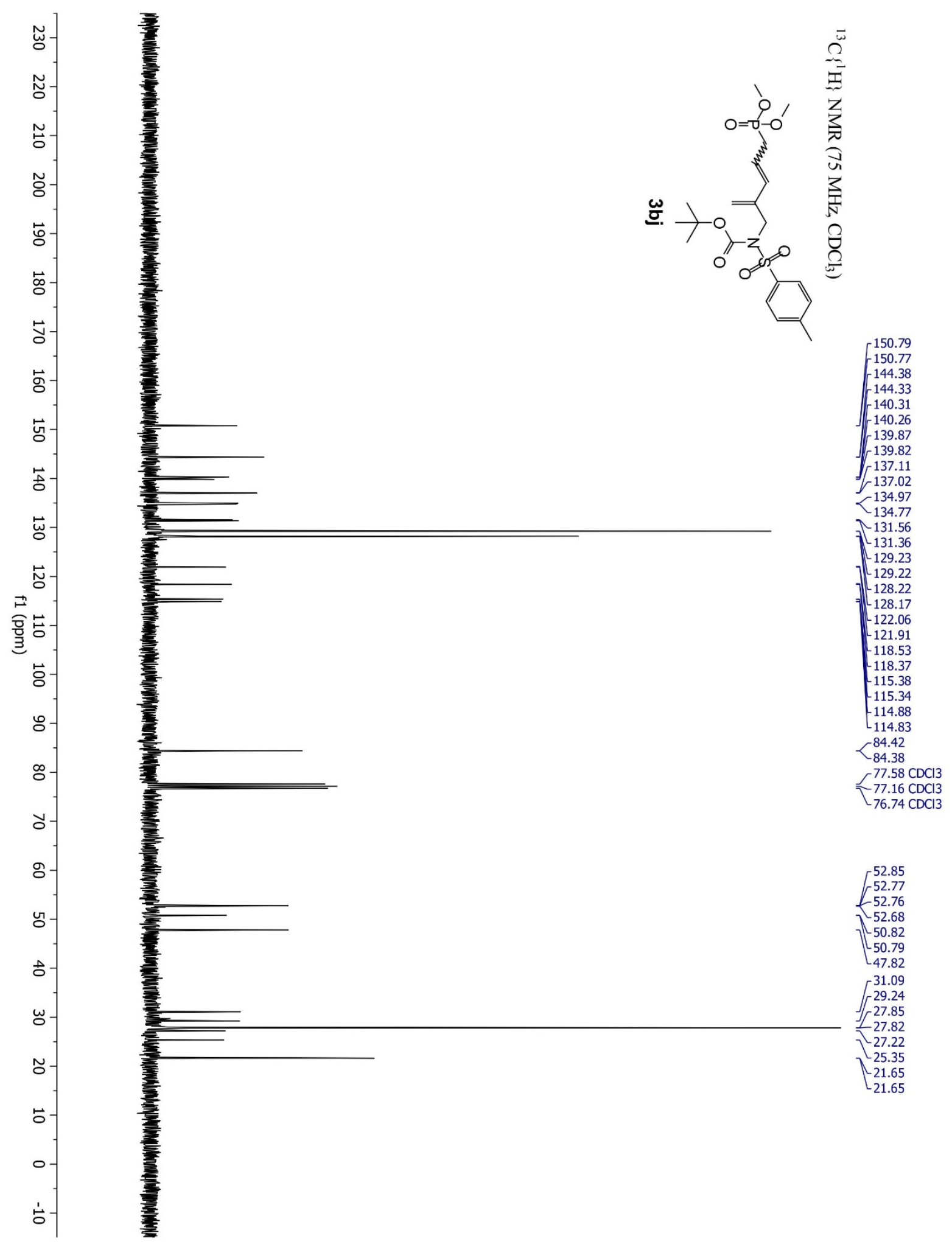




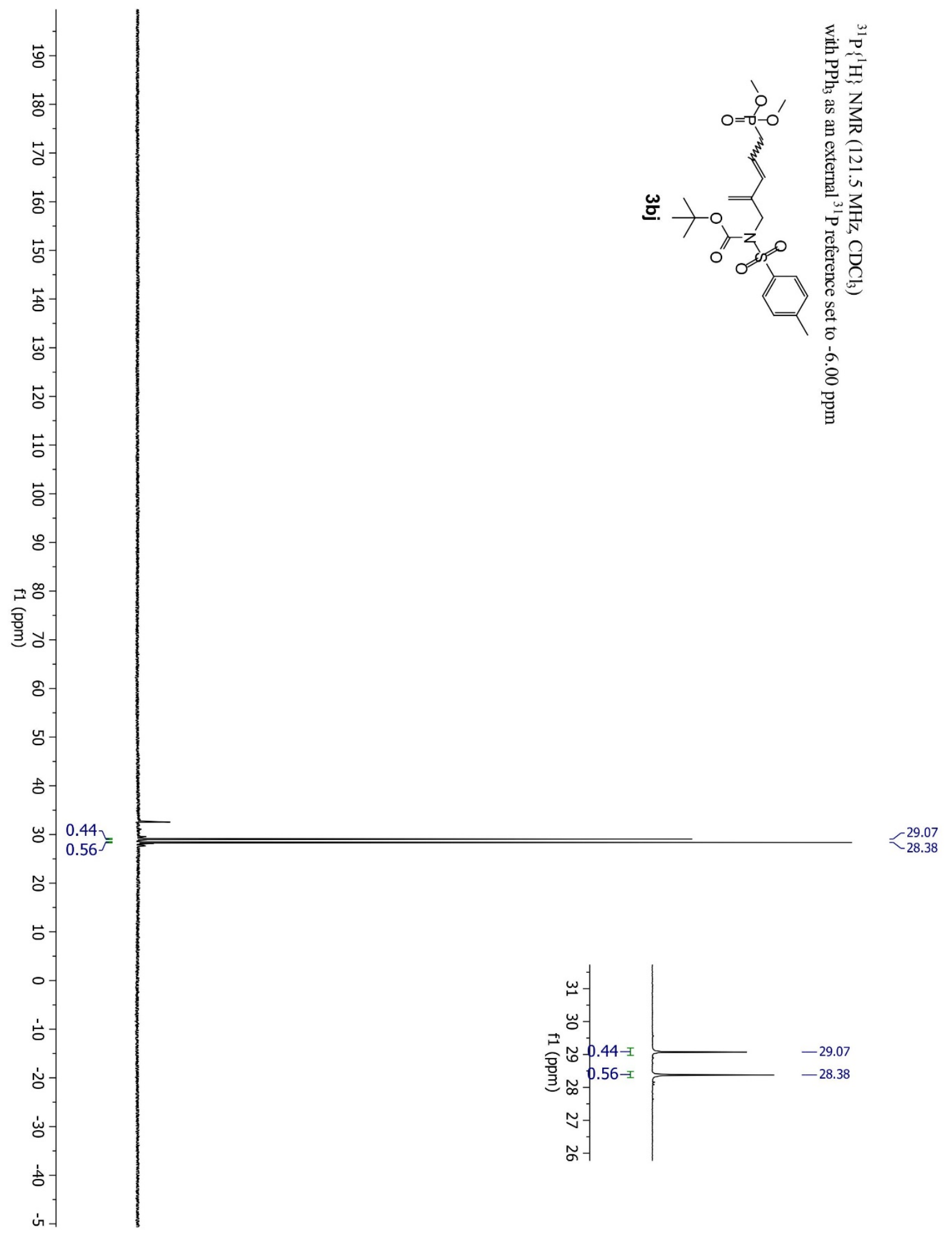




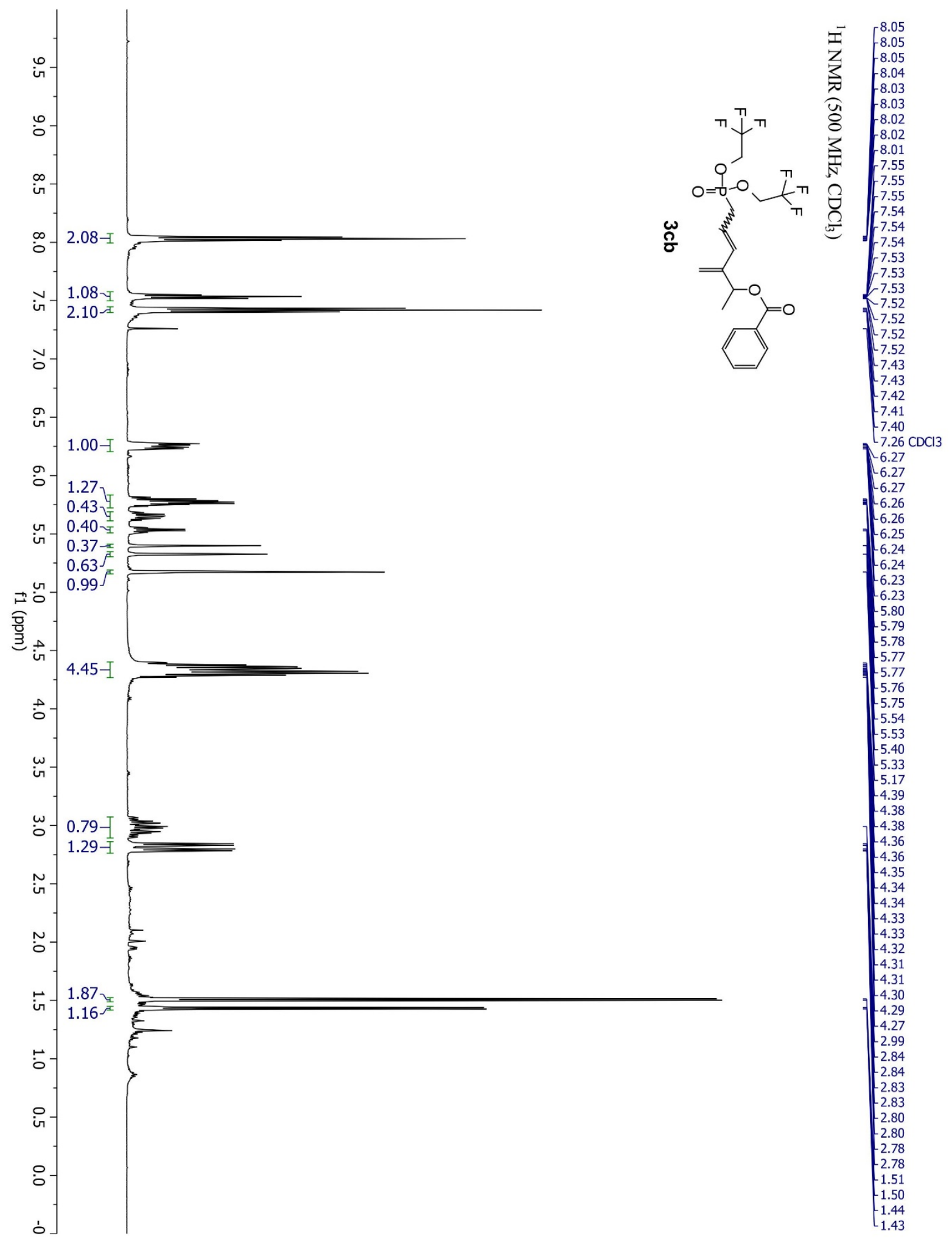




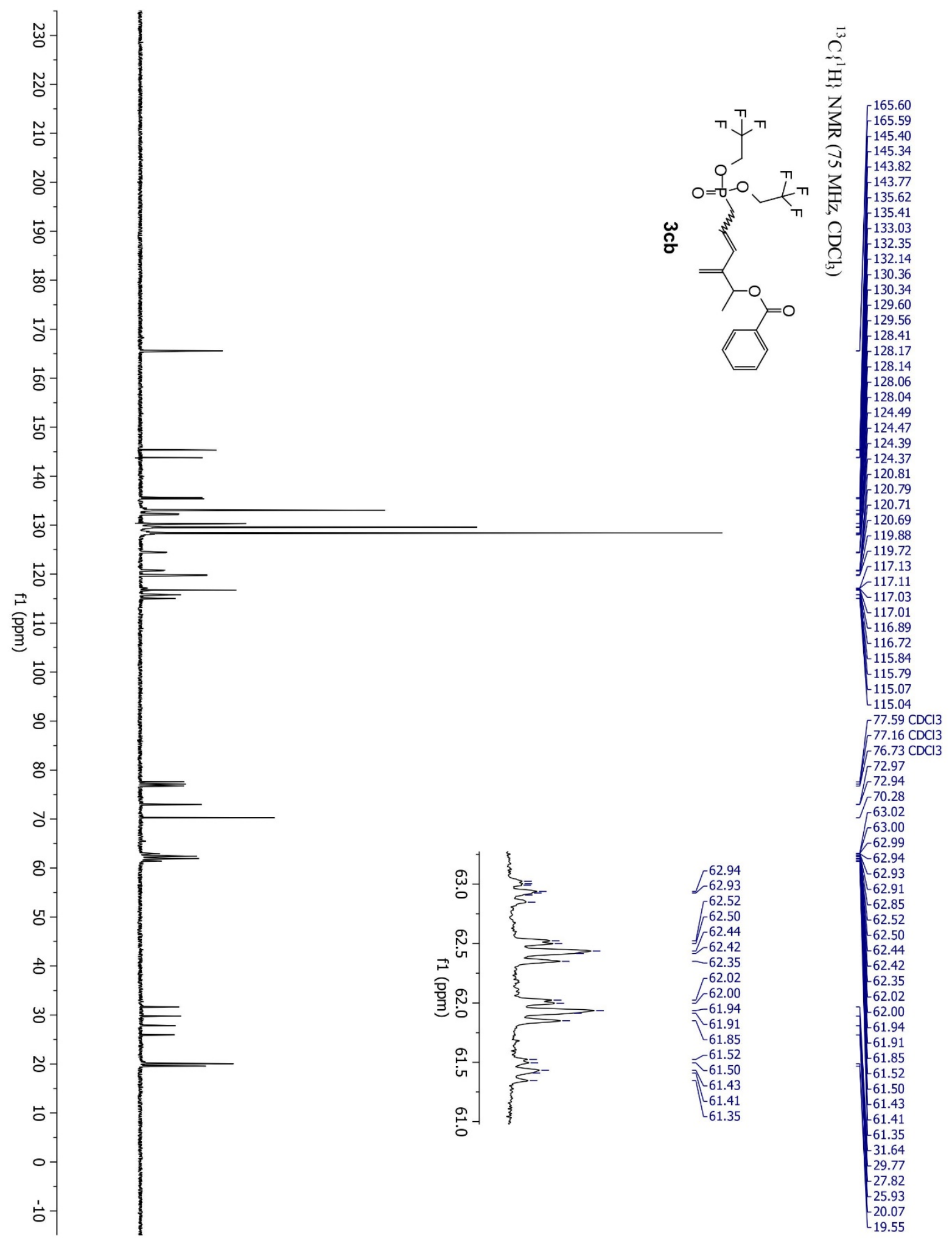




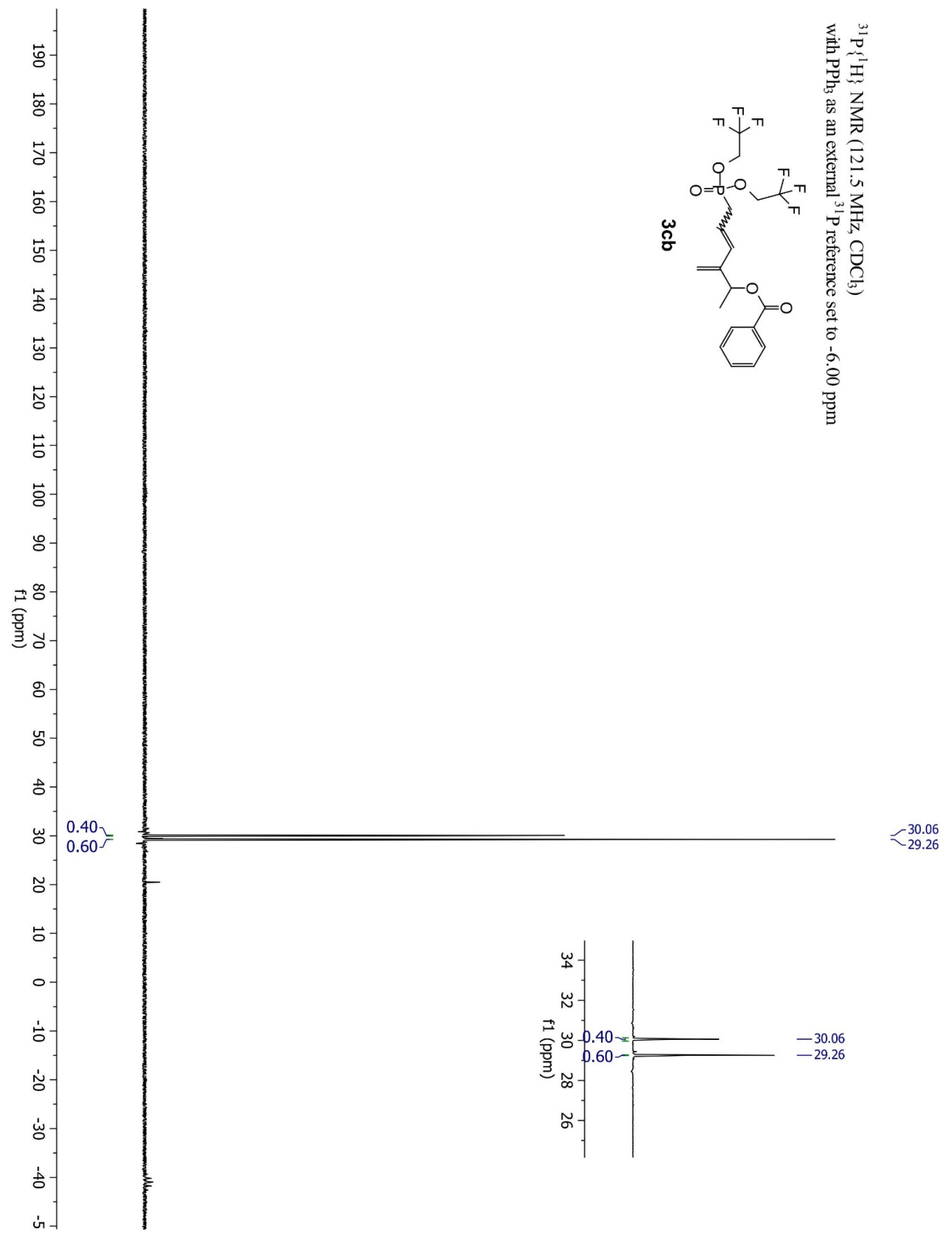




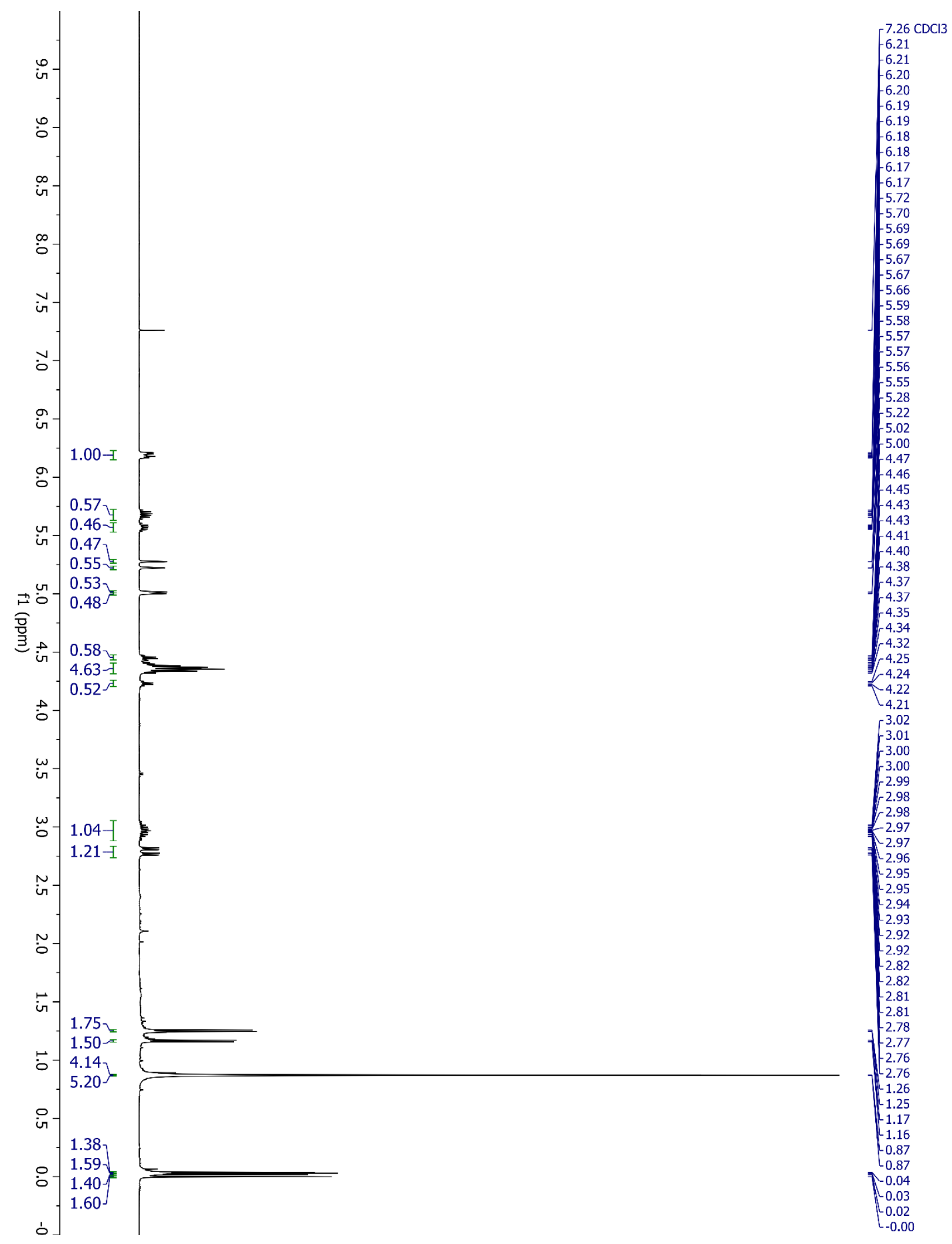




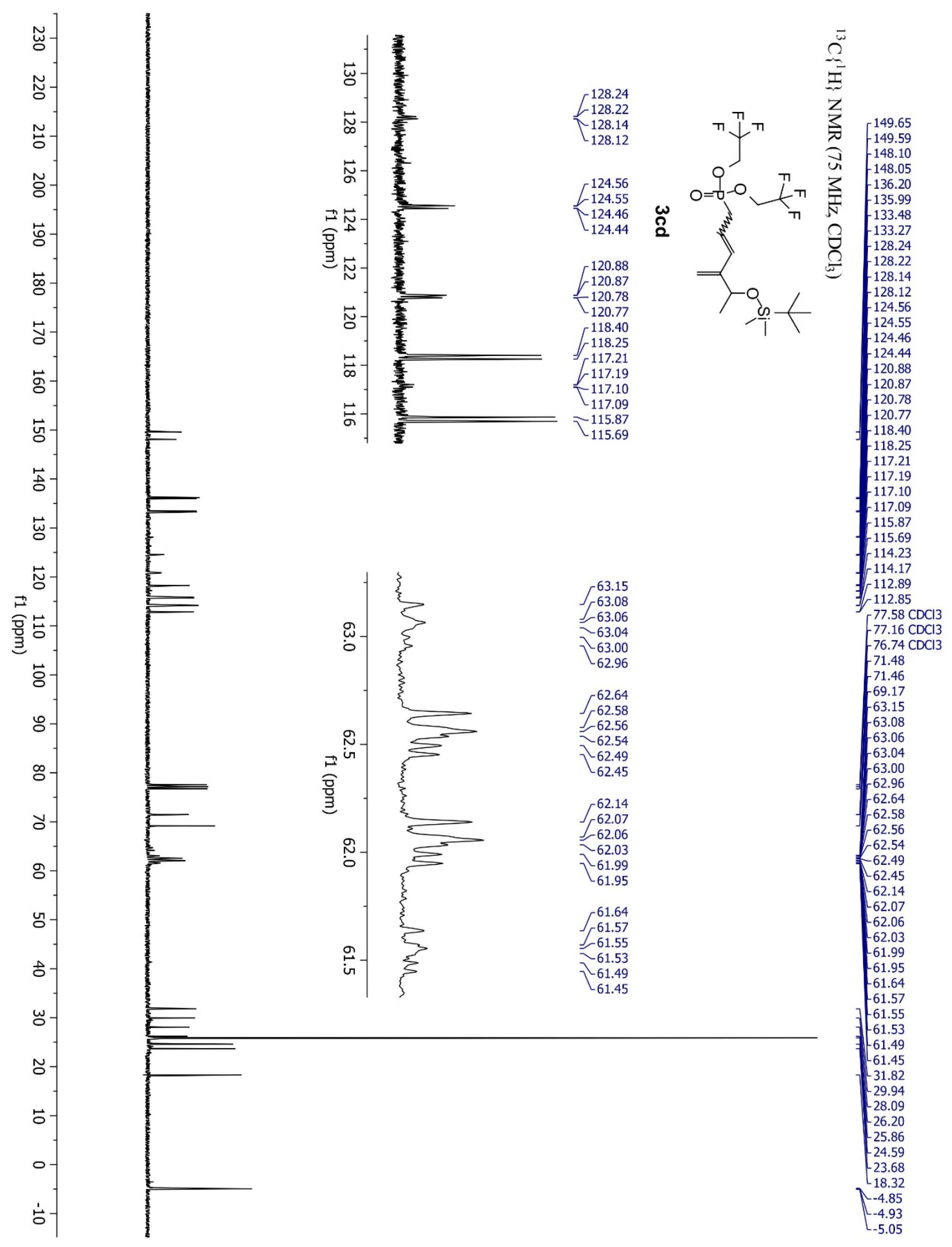




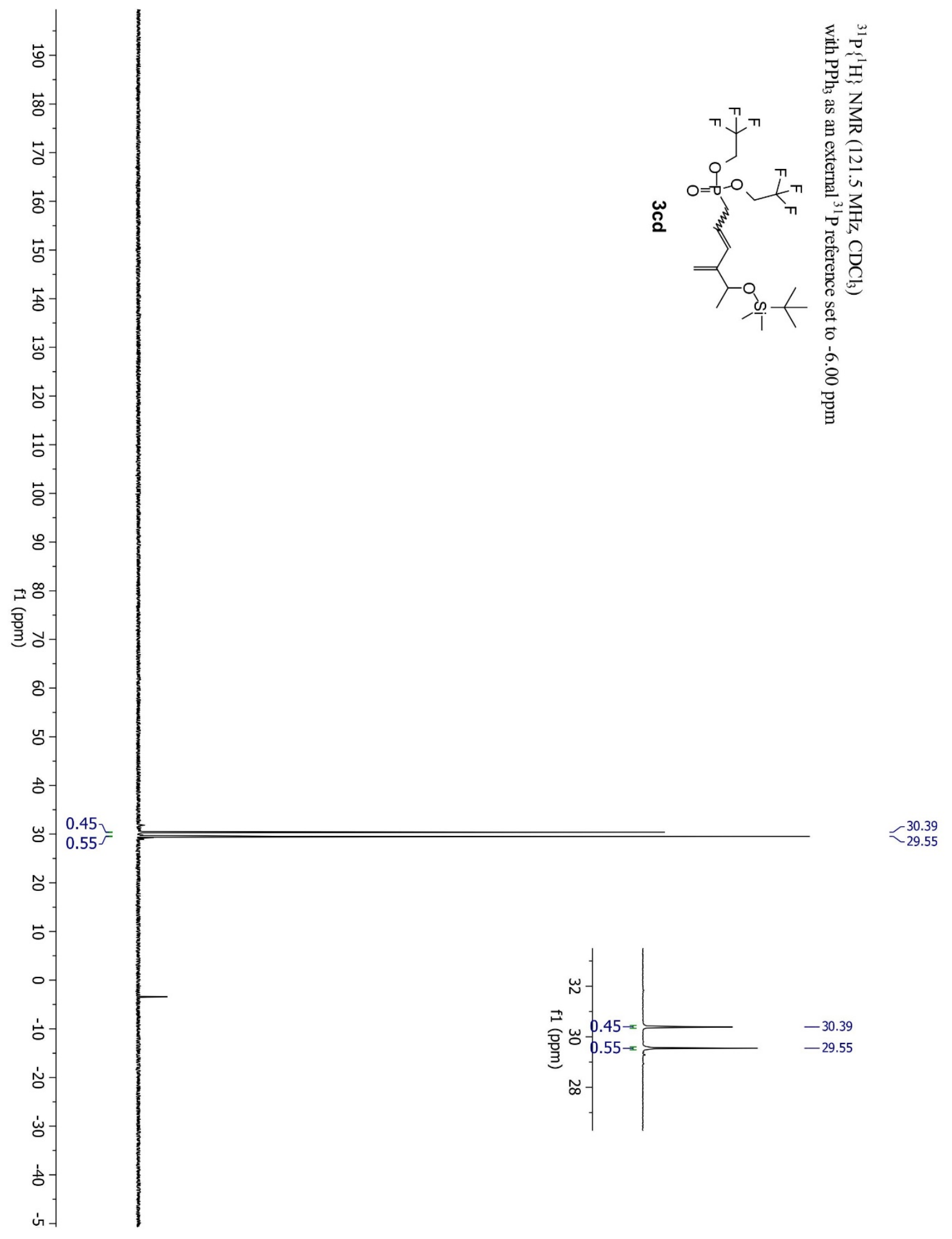




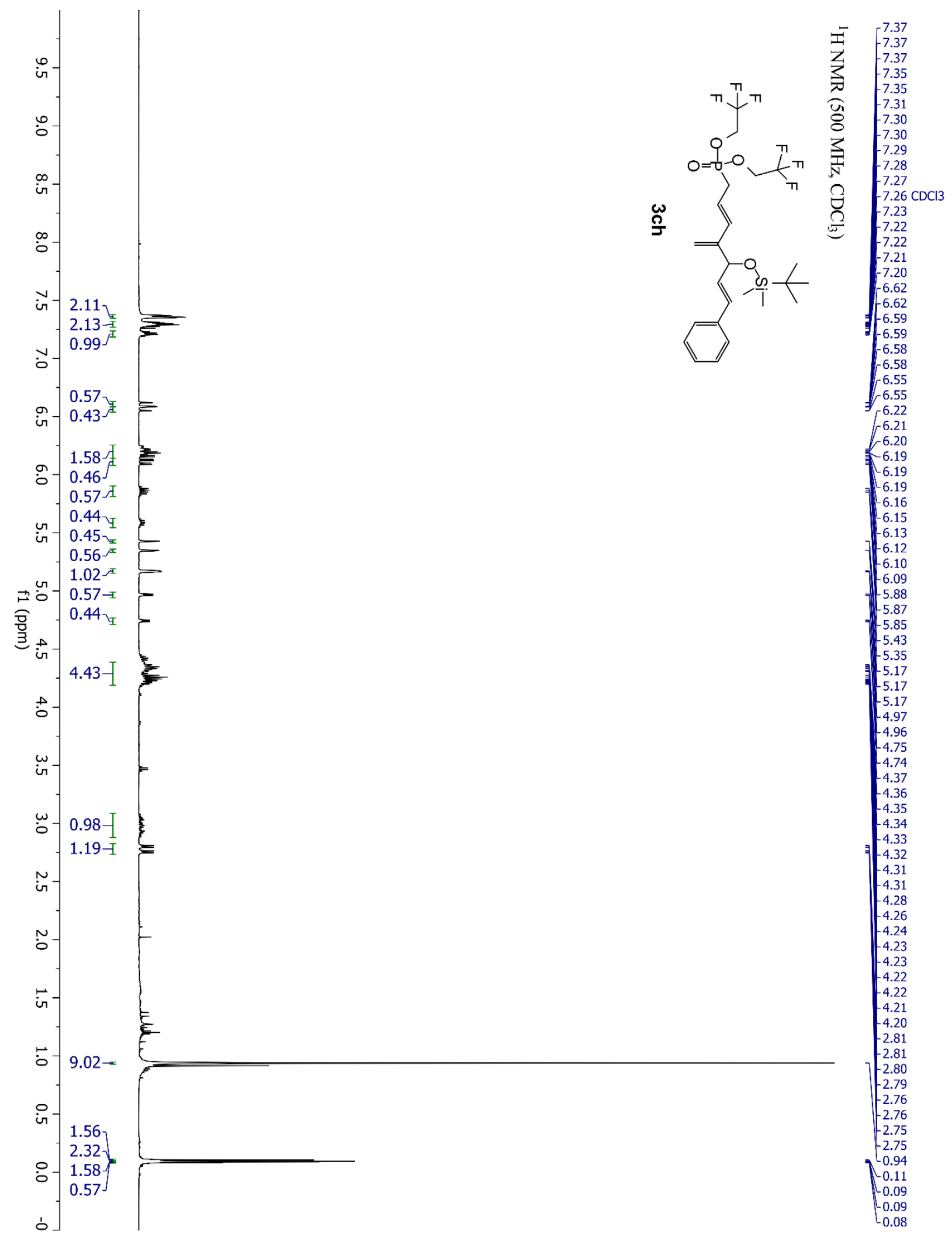




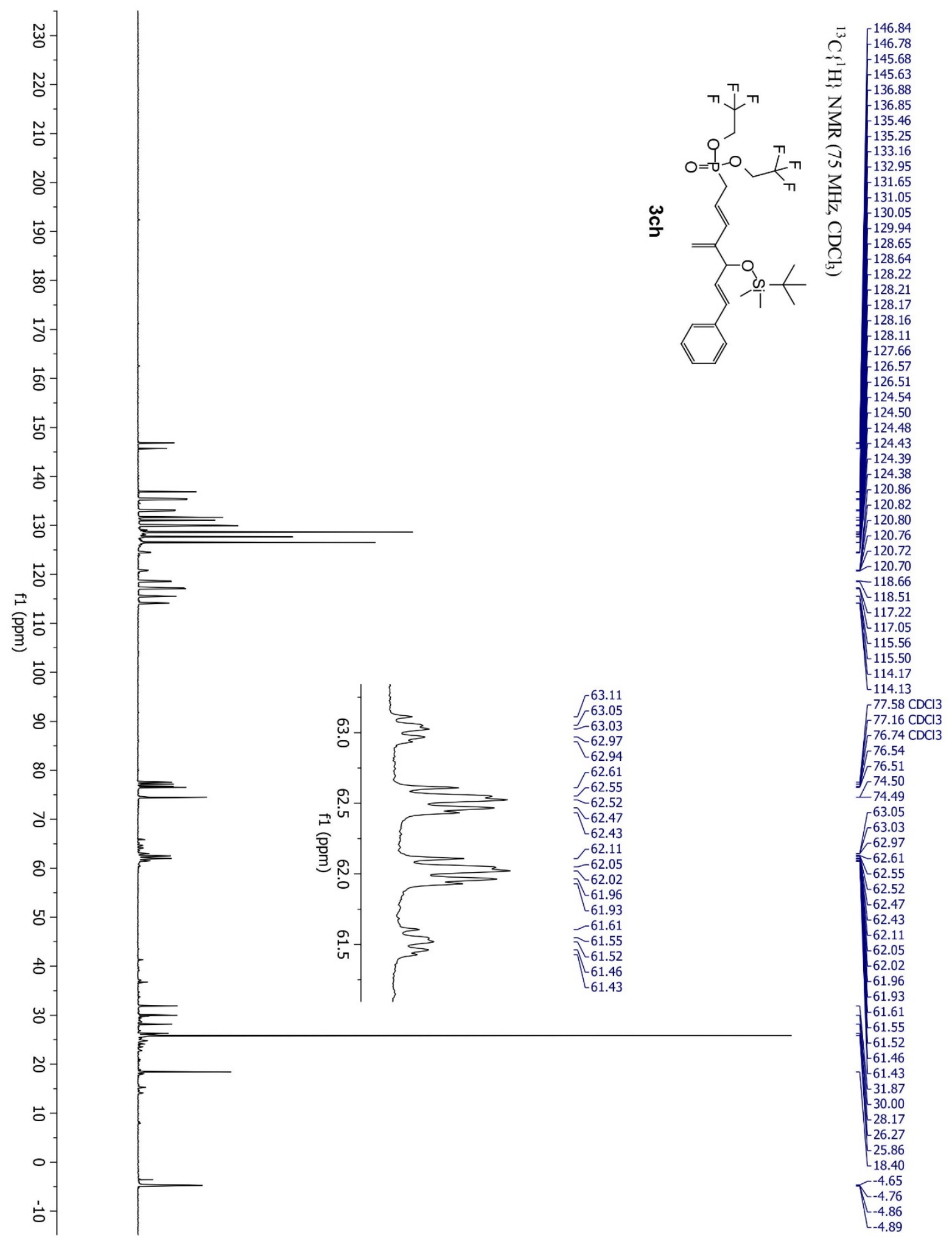




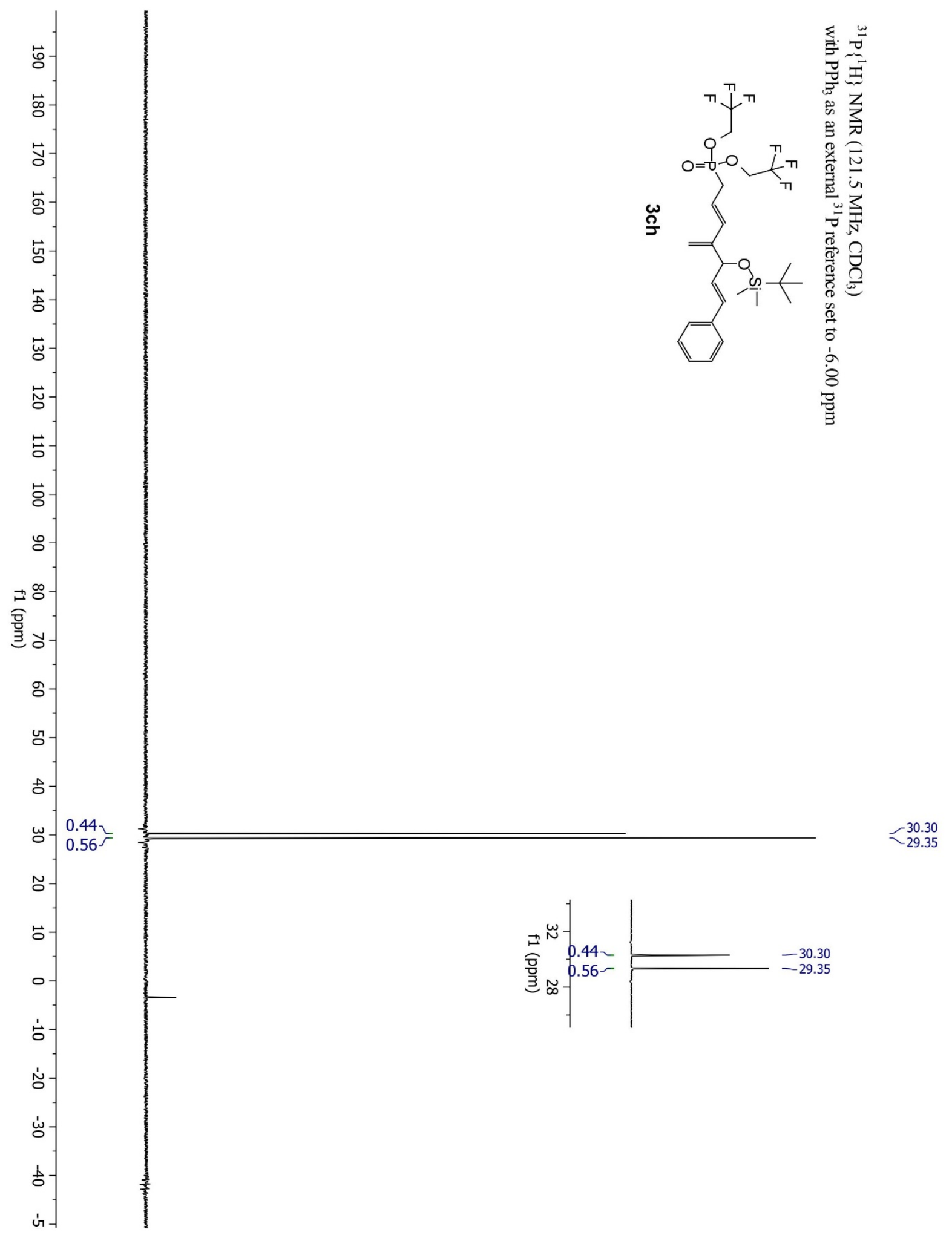




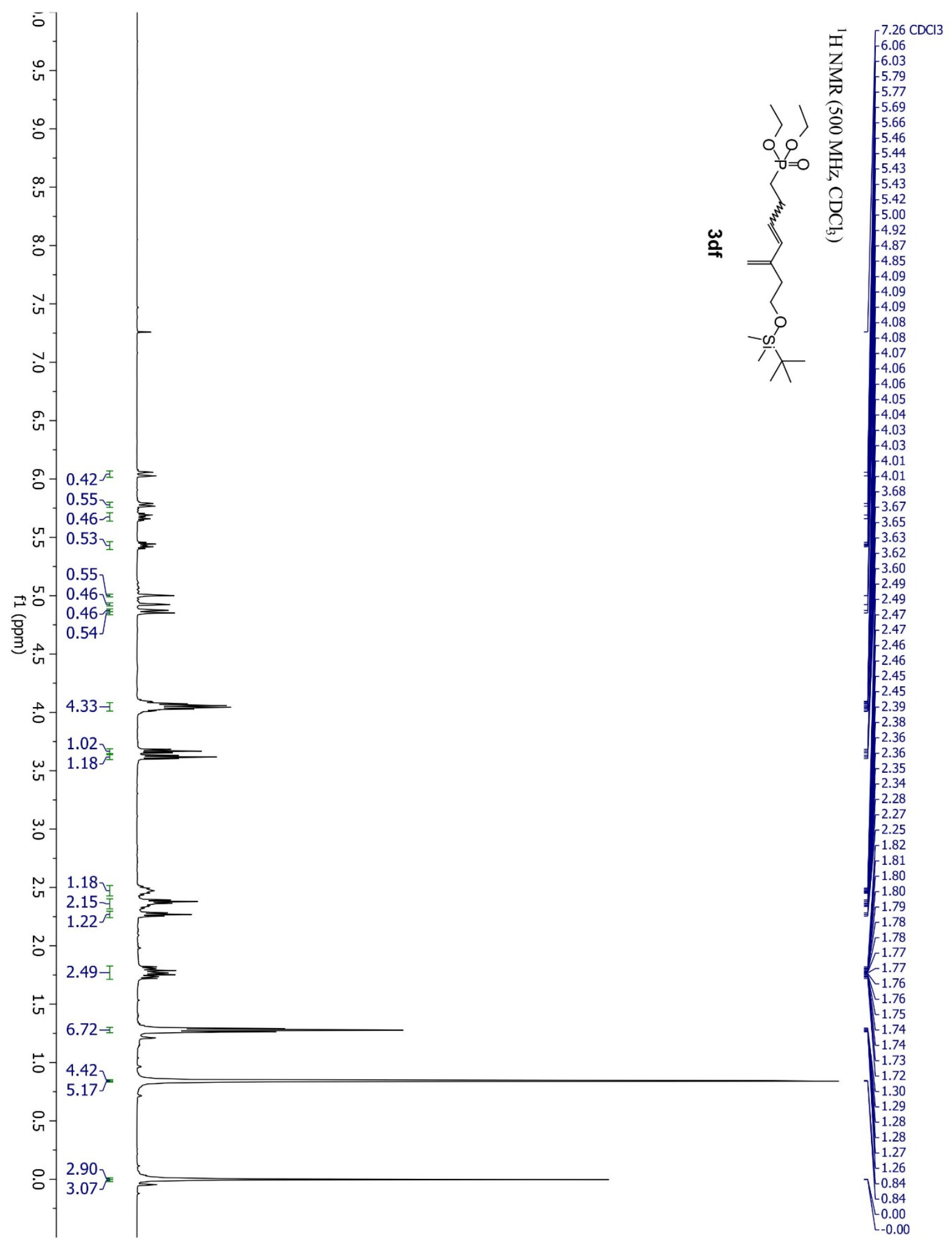



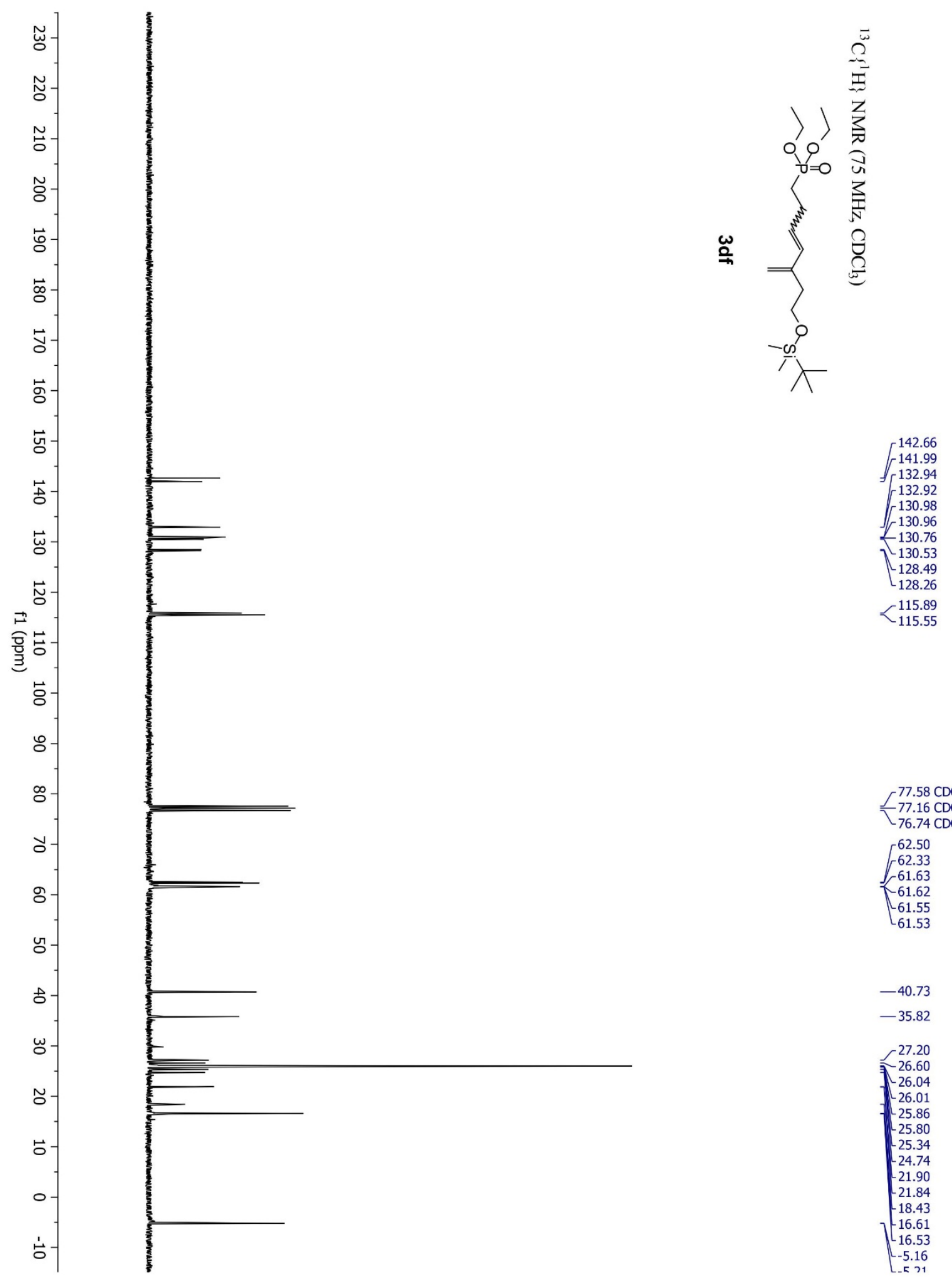

$77.58 \mathrm{CDCl} 3$
$-77.16 \mathrm{CDCl} 3$ ${ }_{76.74 \mathrm{CDCl}^{3}}$

62.50

62.33

J 61.63

61.62

$-61.55$

61.53

$-40.73$

$-35.82$

27.20
-26.60

26.60
26.04

26.0

25.86

$-25.80$

$-25.34$

24.74

21.90

21.84

$-18.43$

$-16.61$

16.53

$-5.16$ 


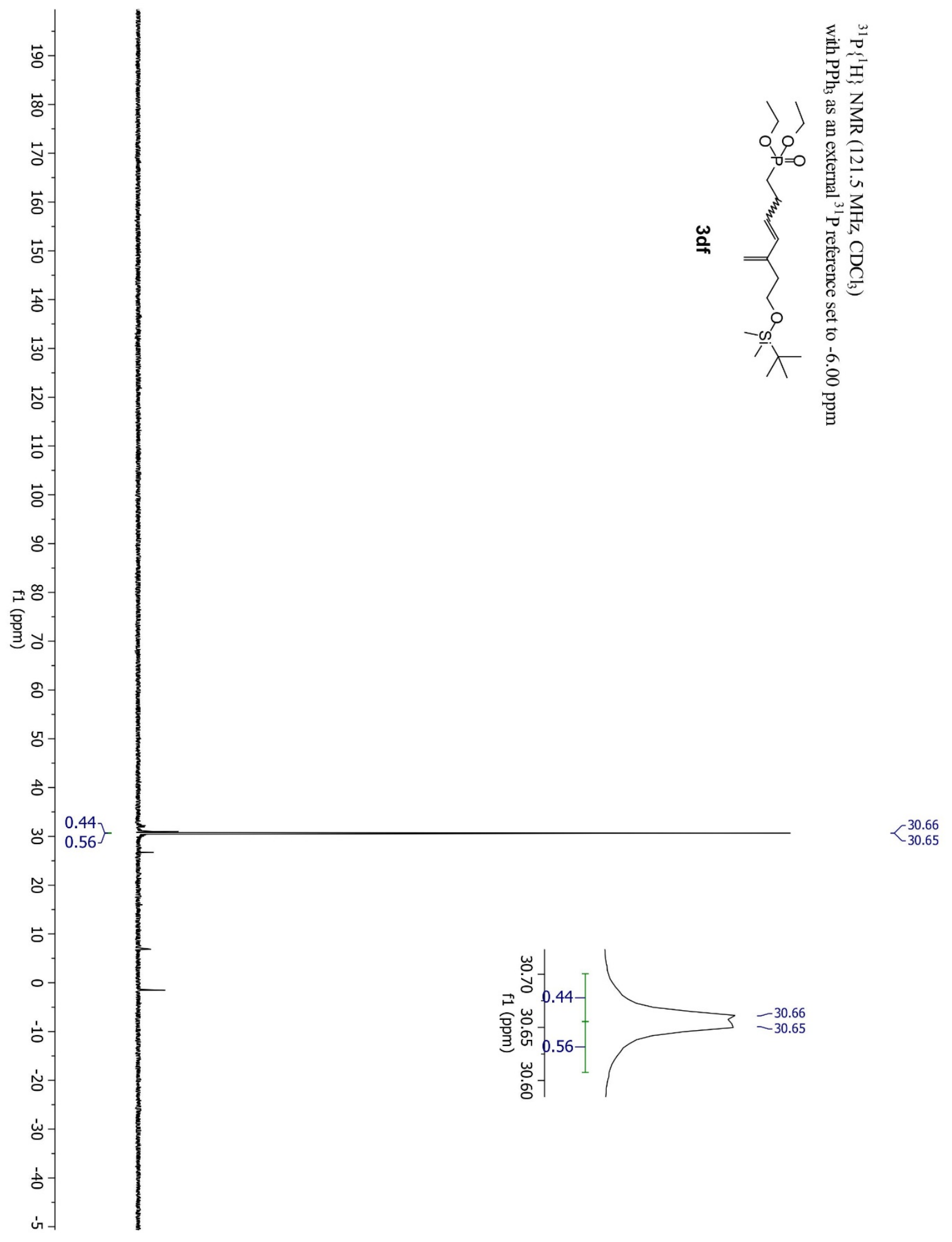




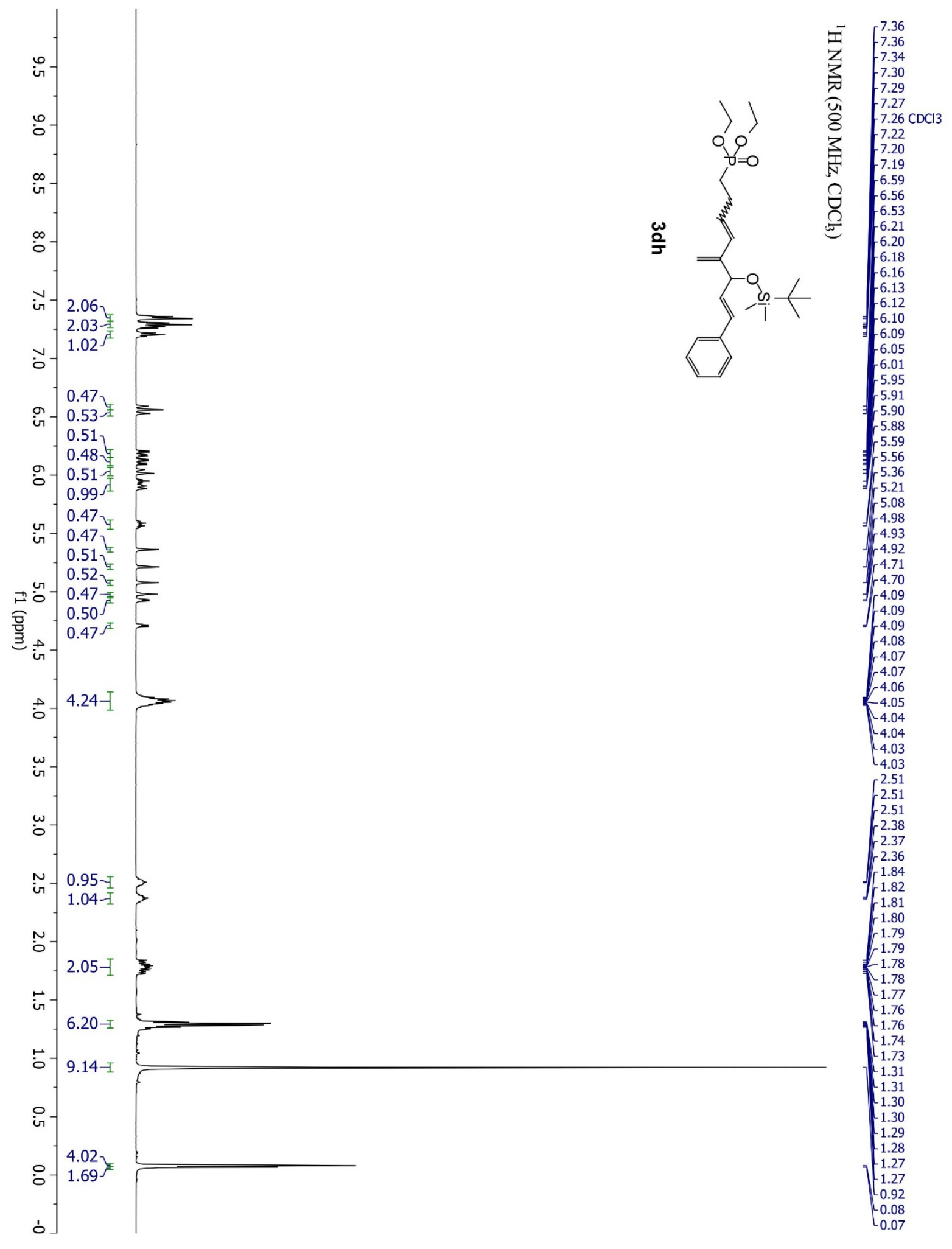




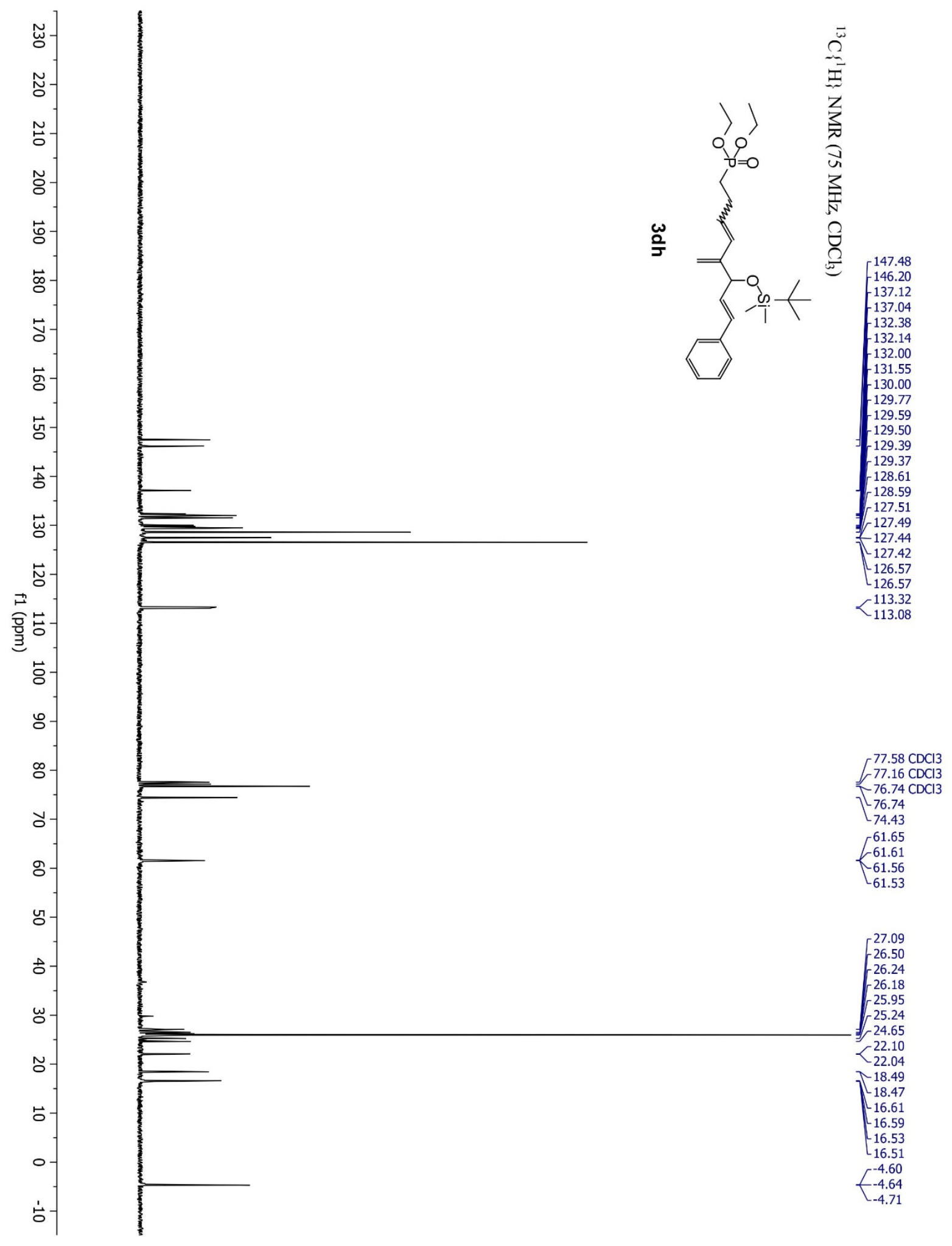




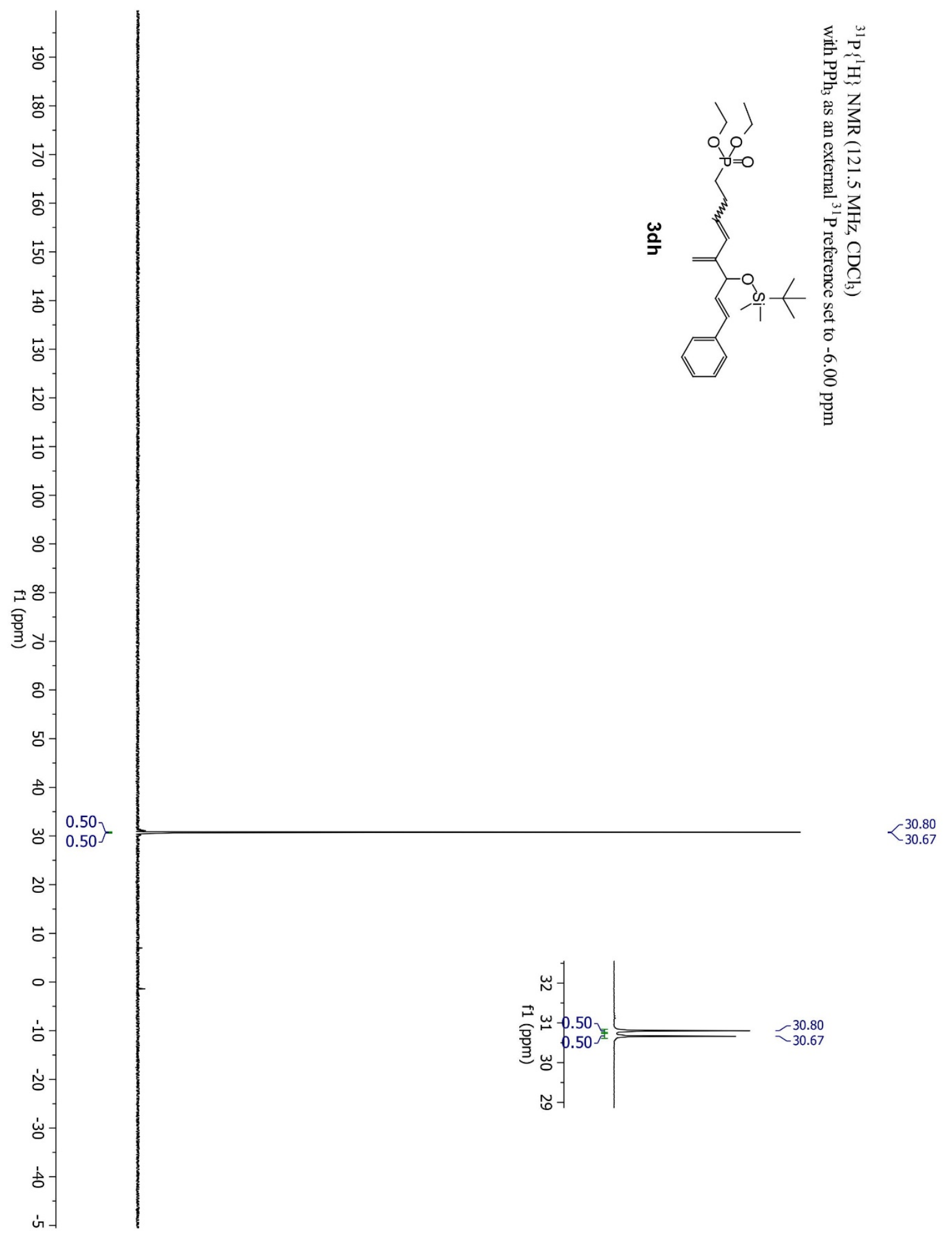



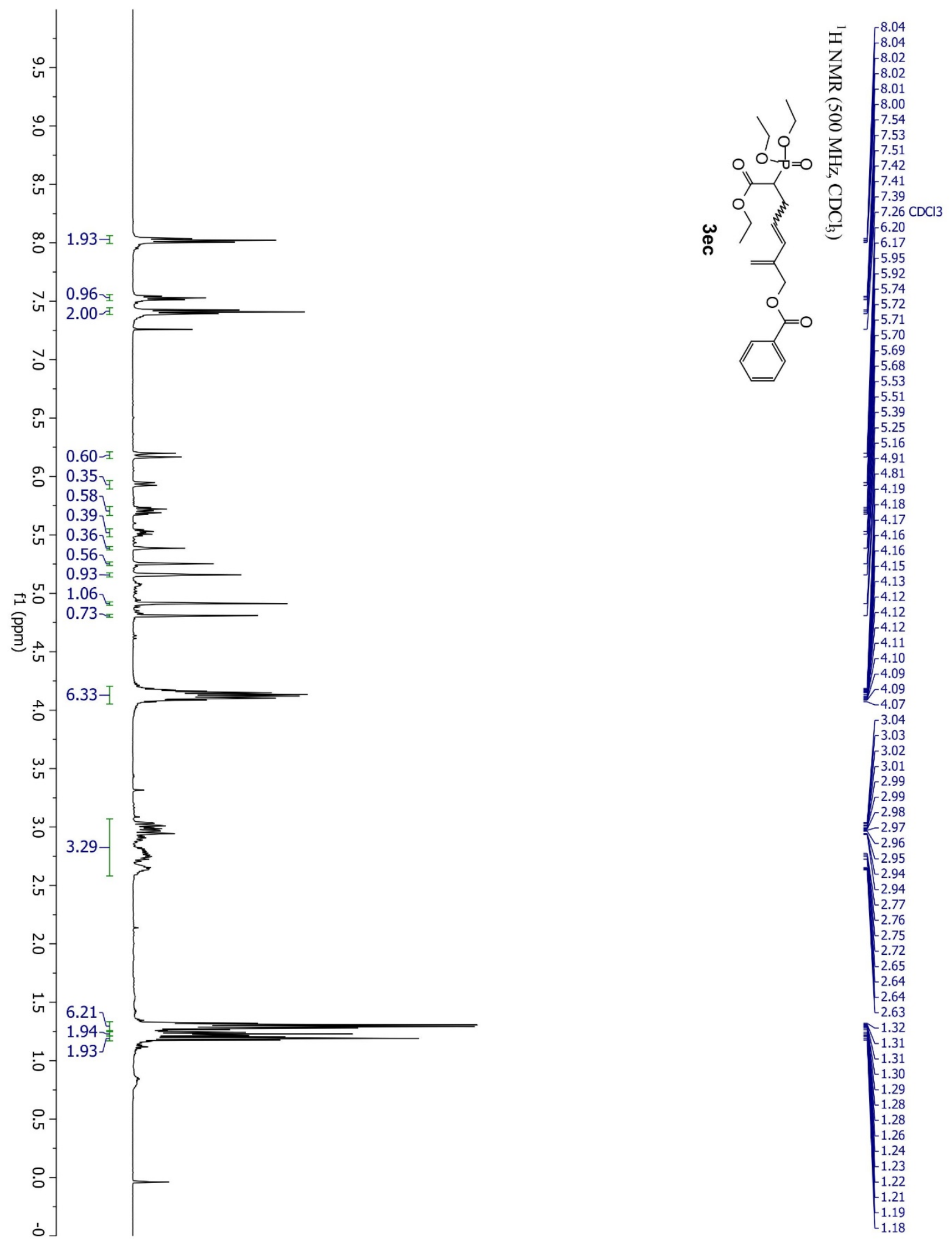


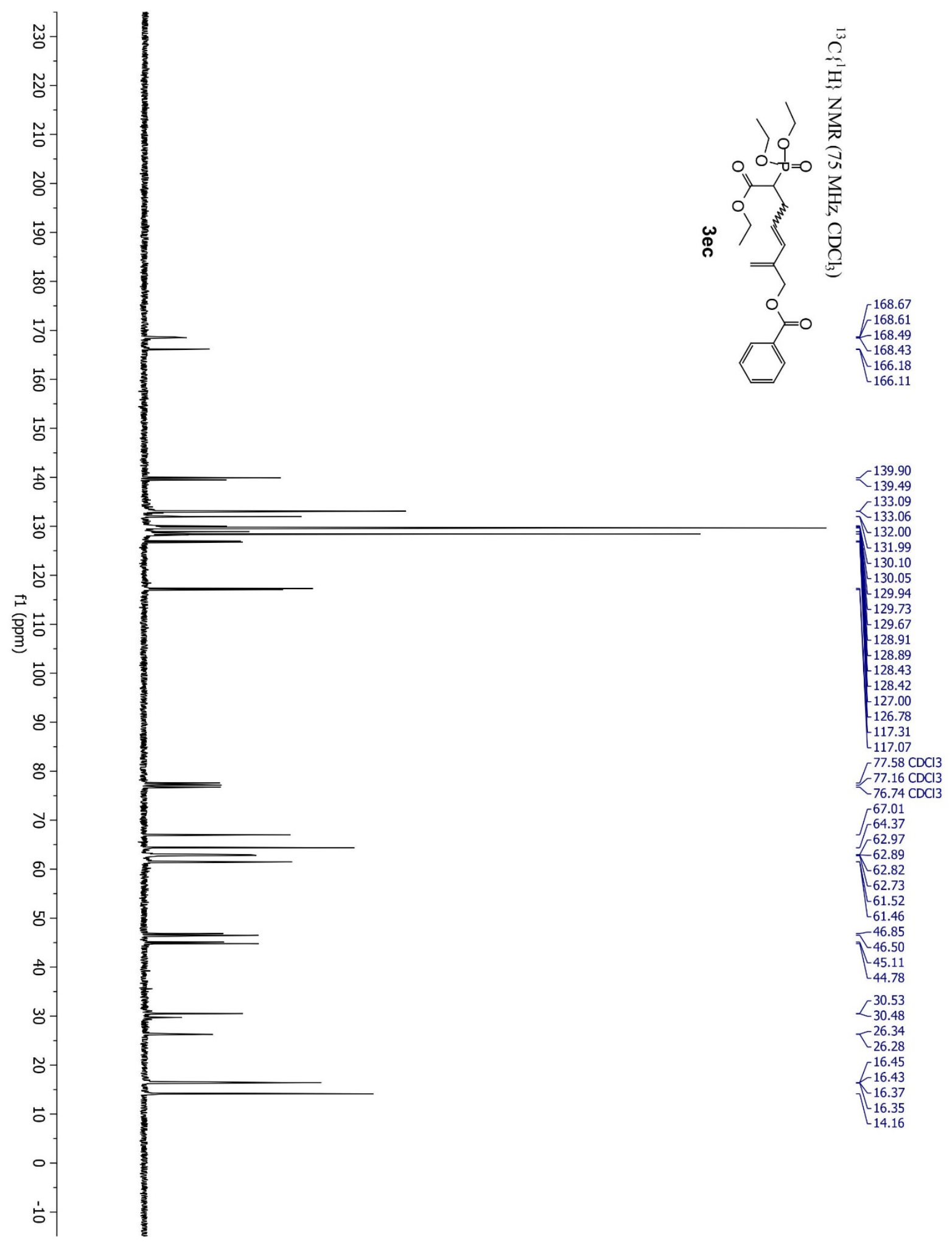




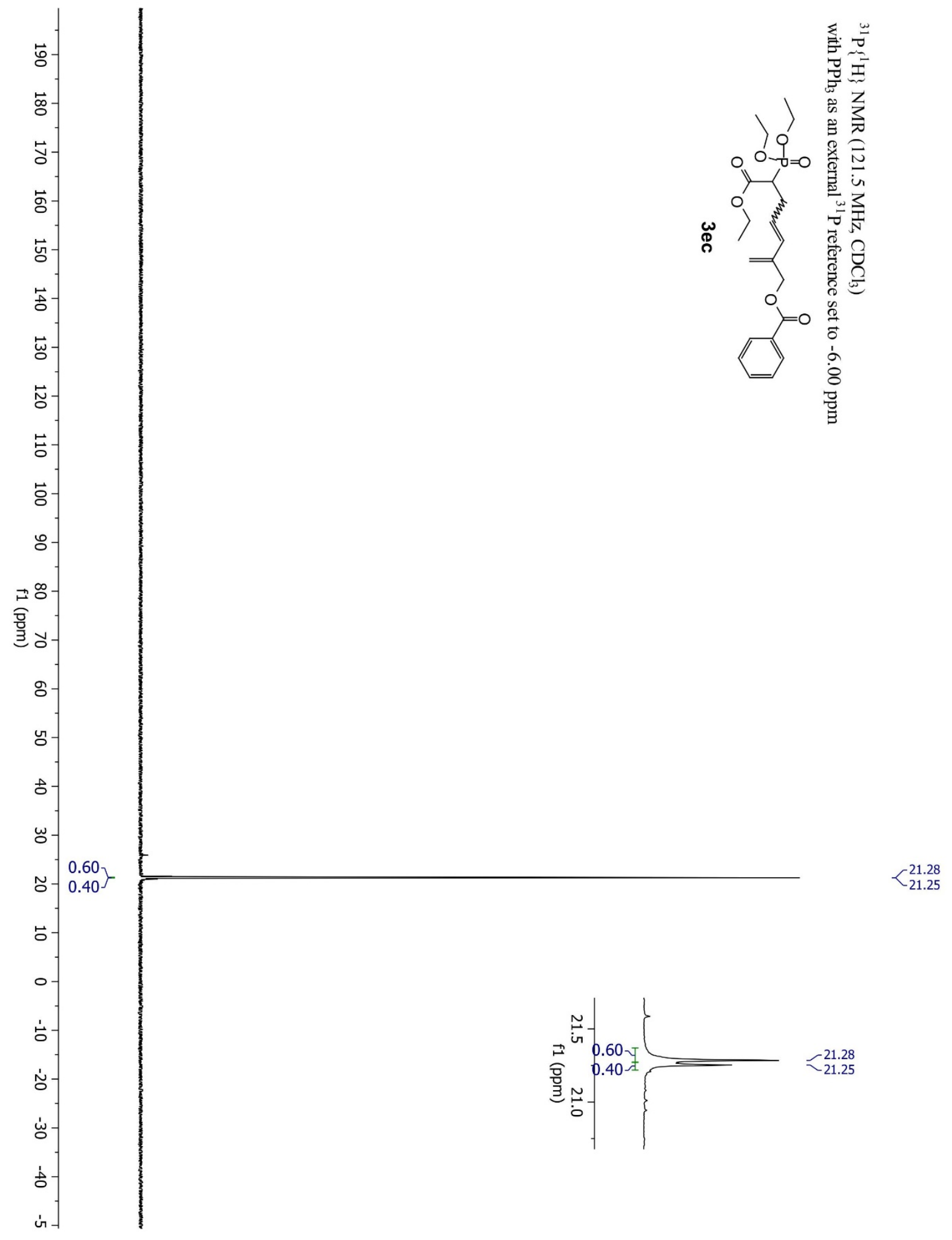




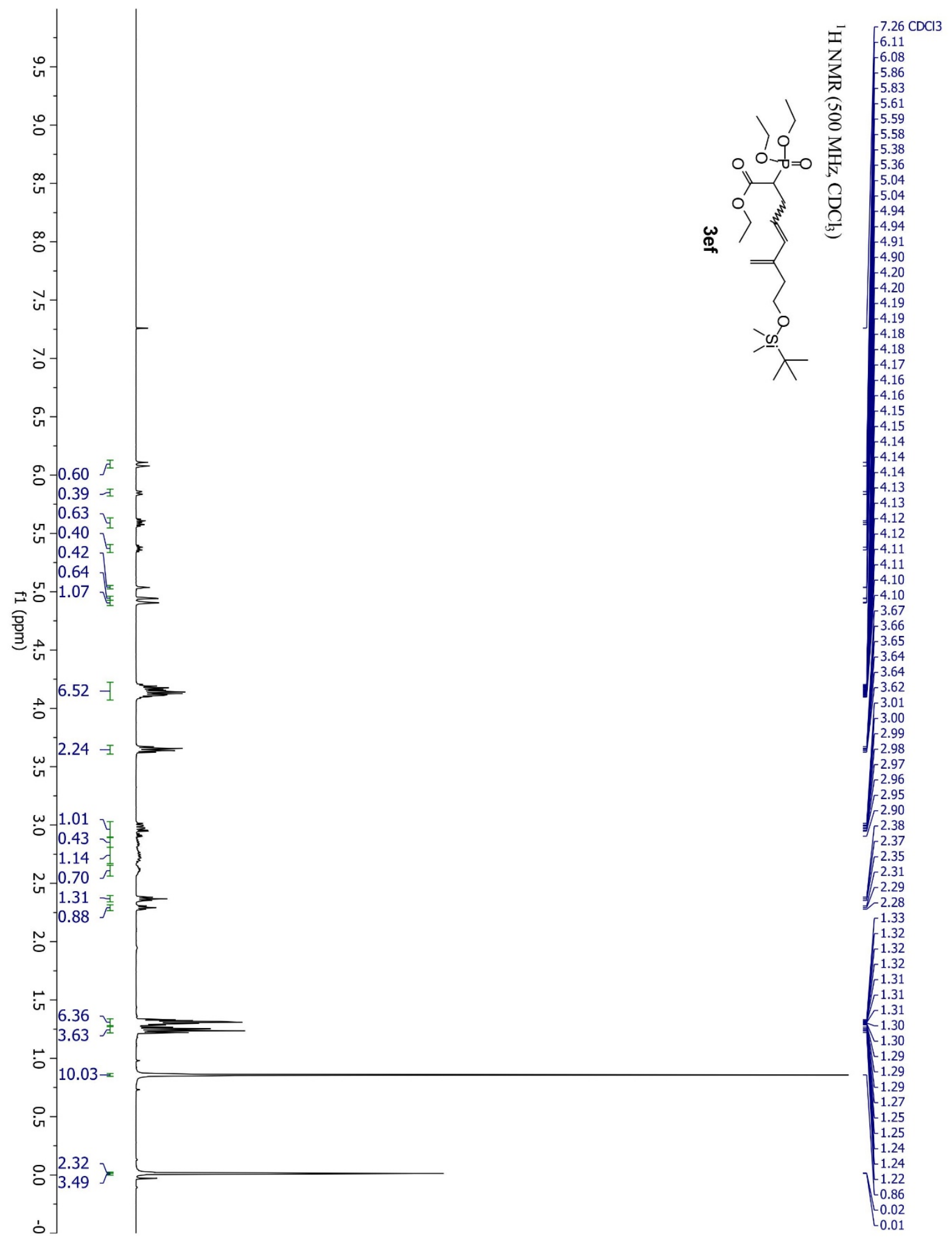




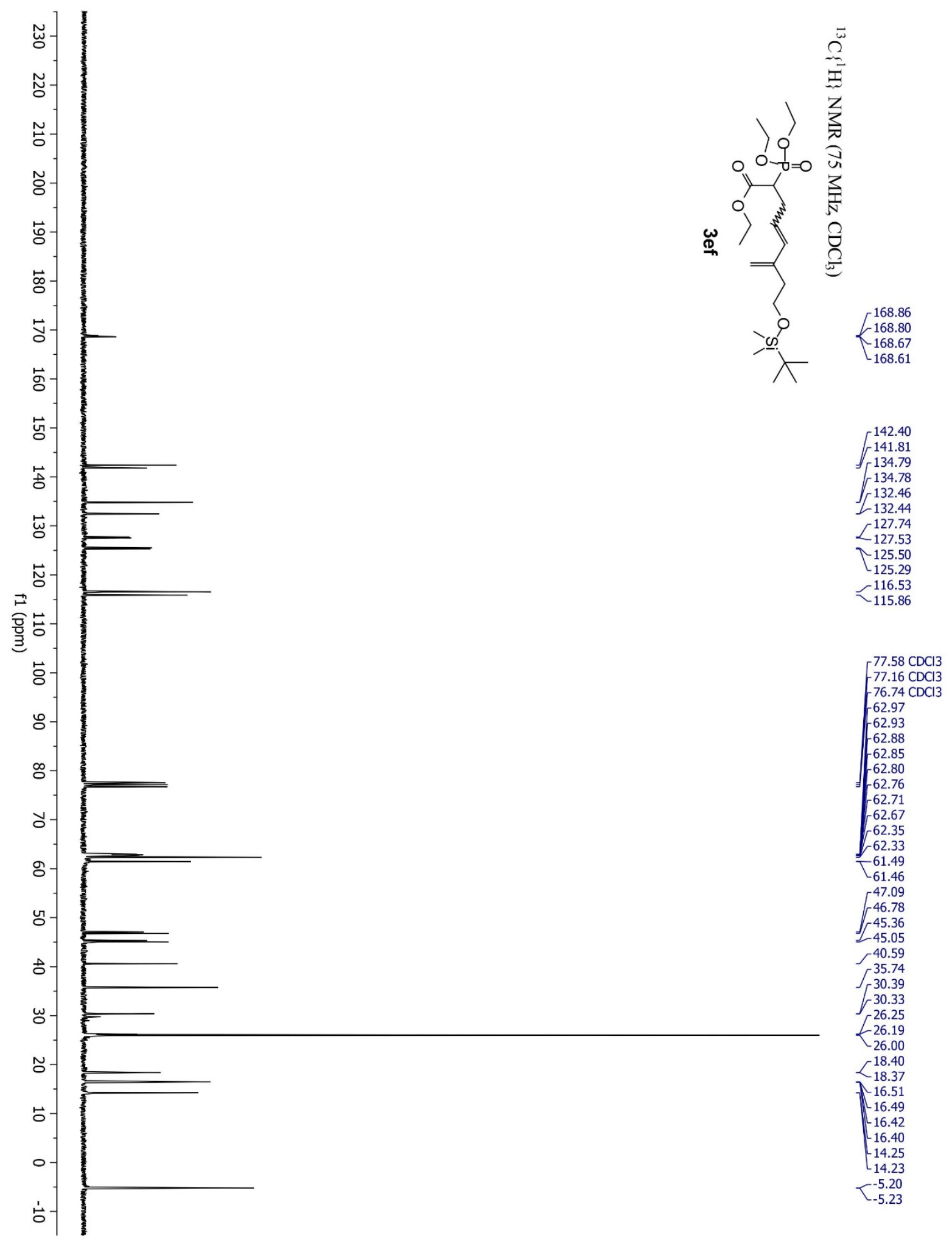




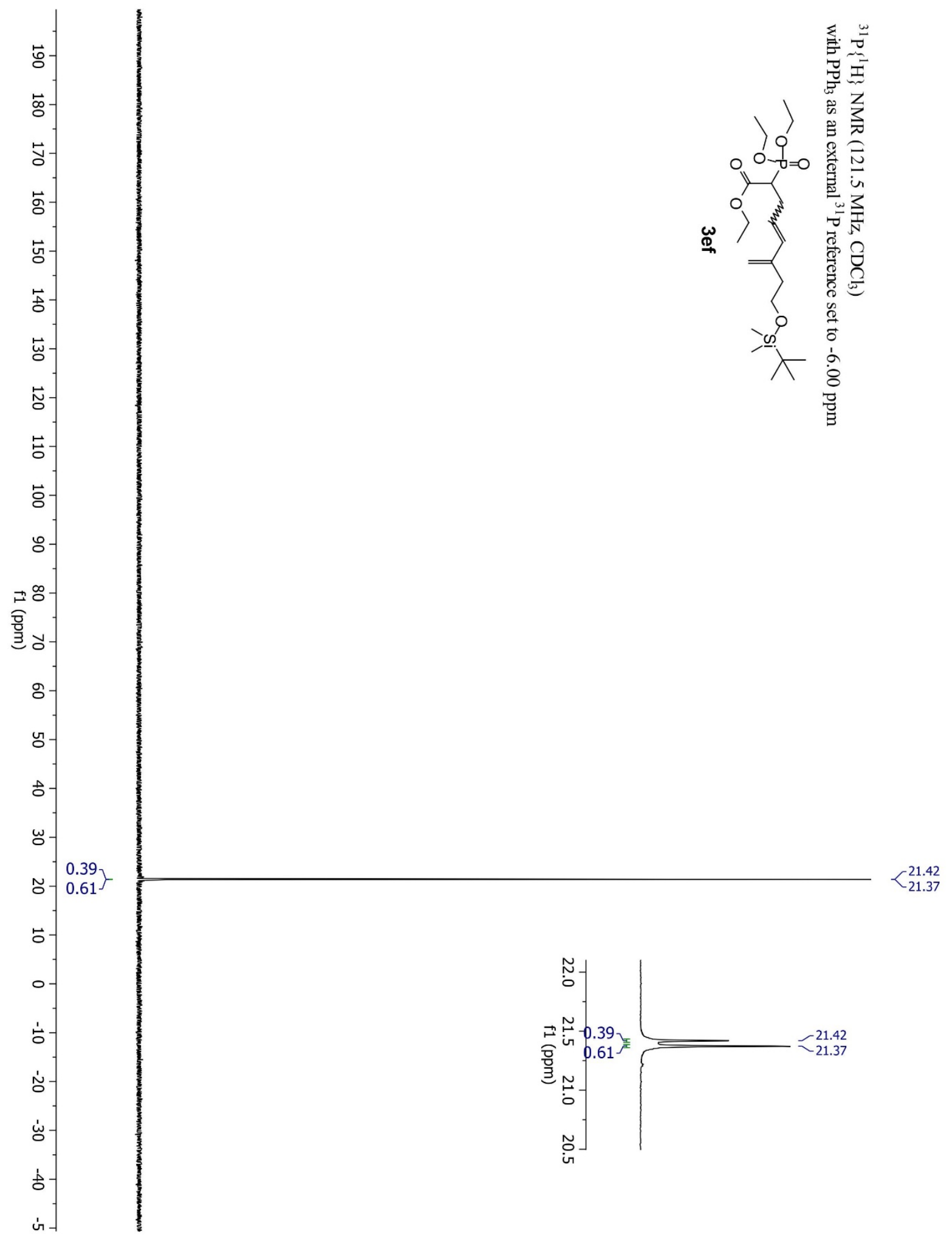




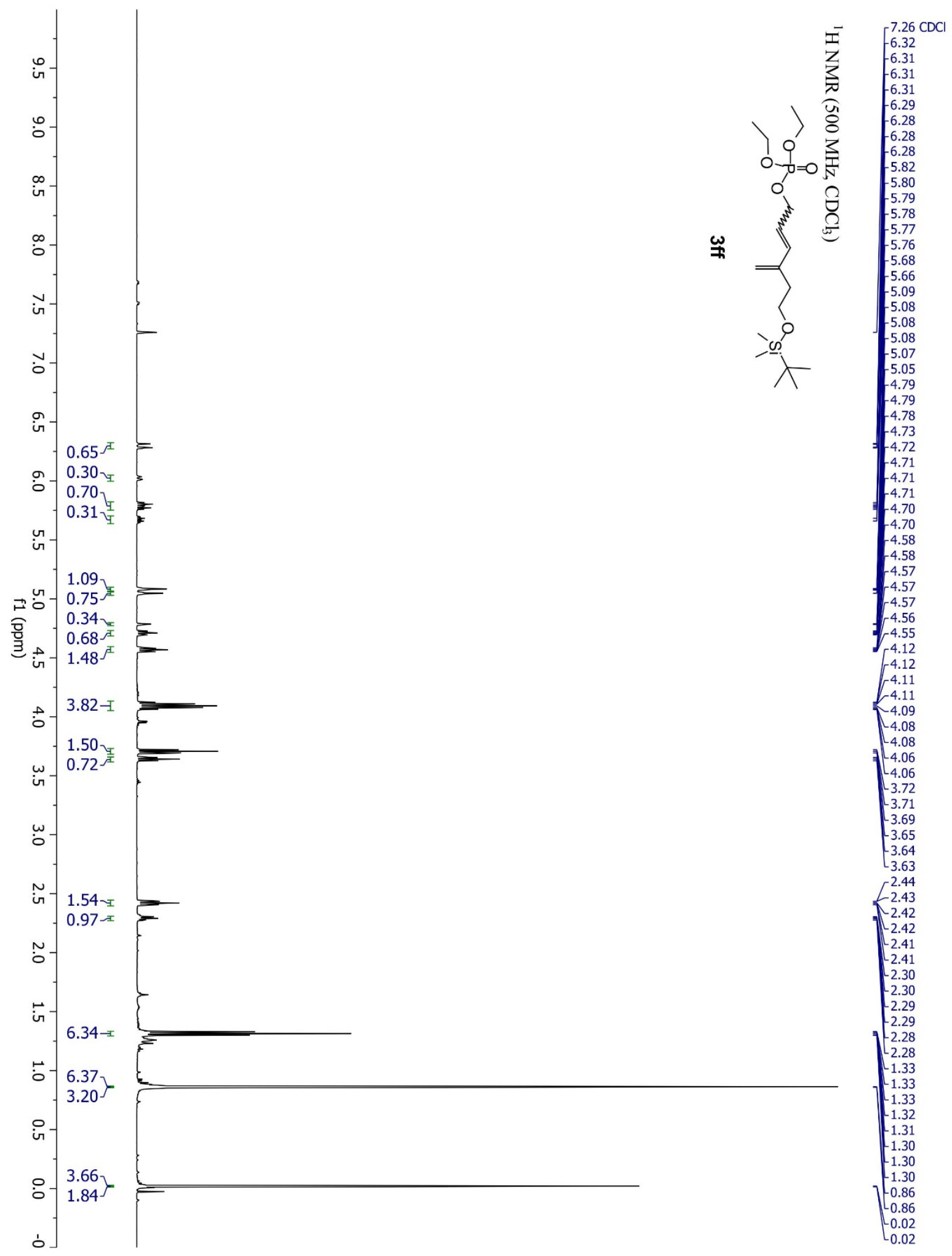




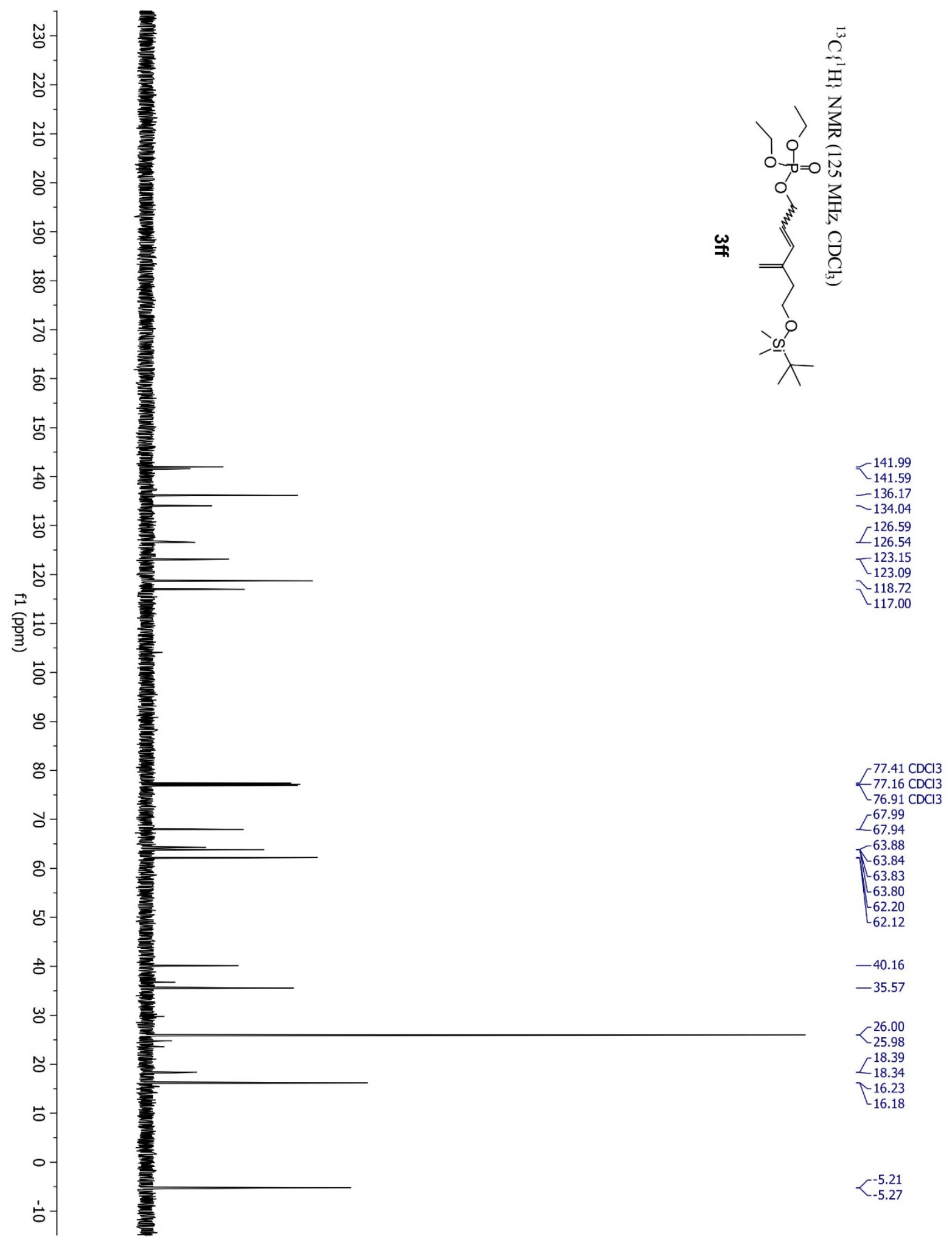




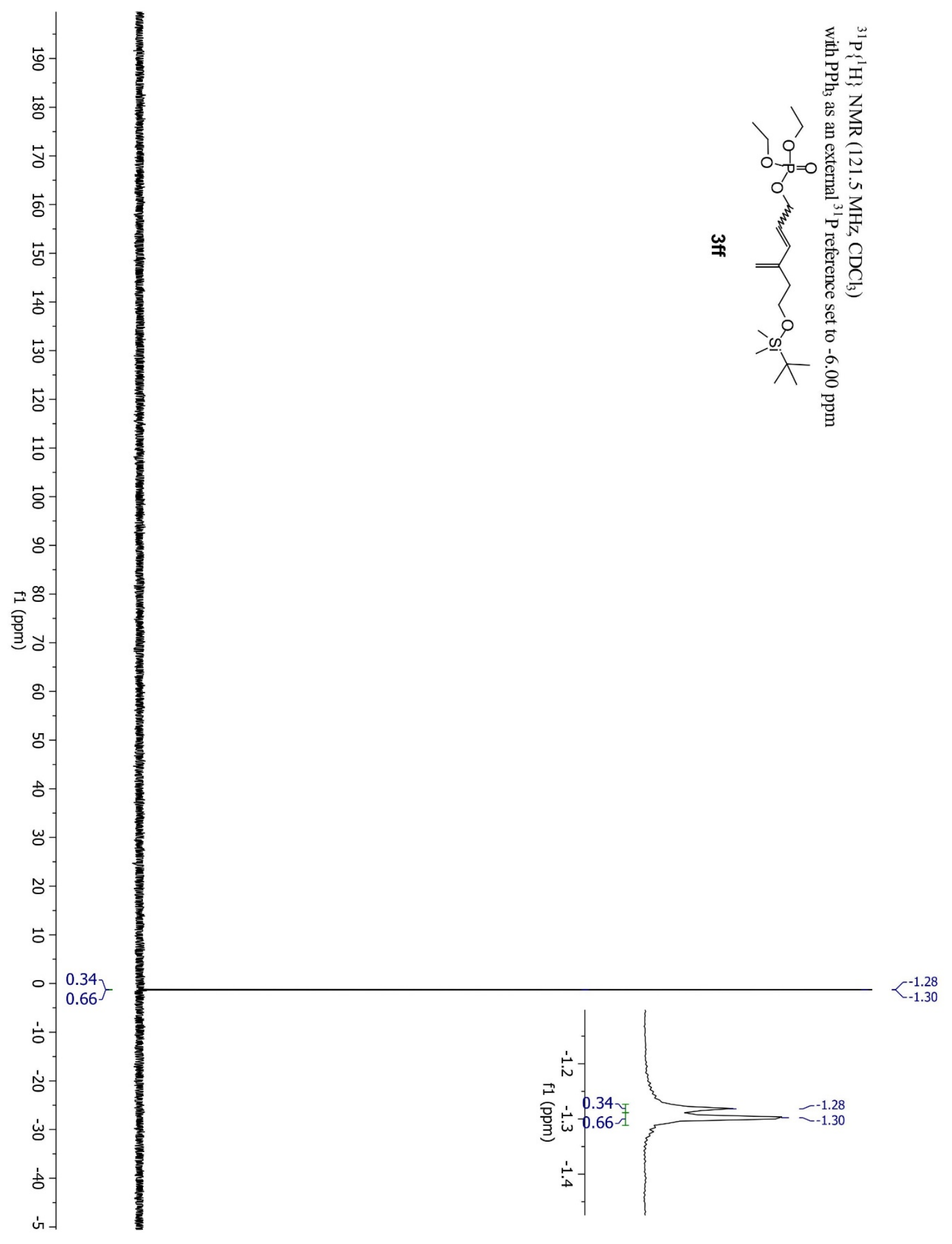




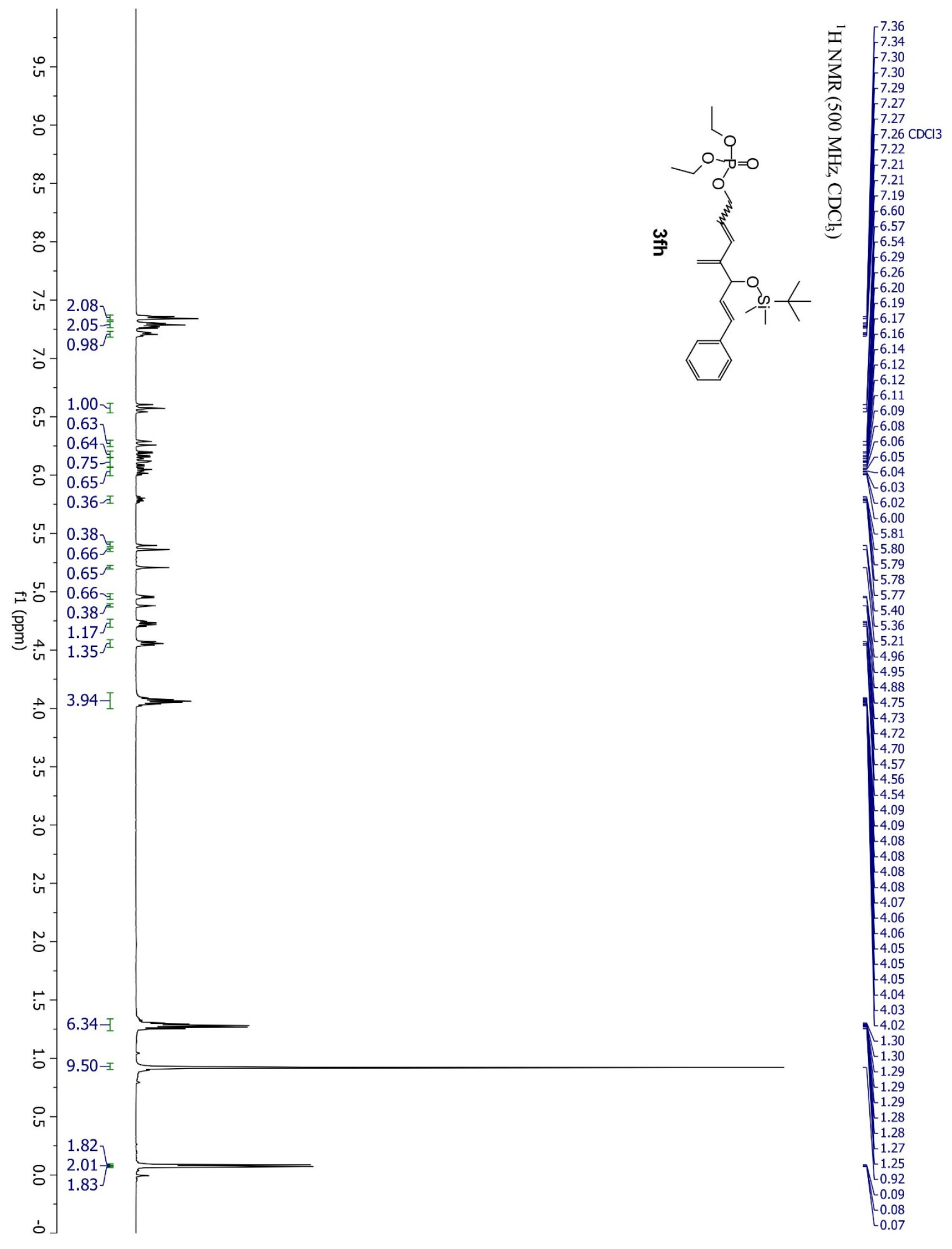




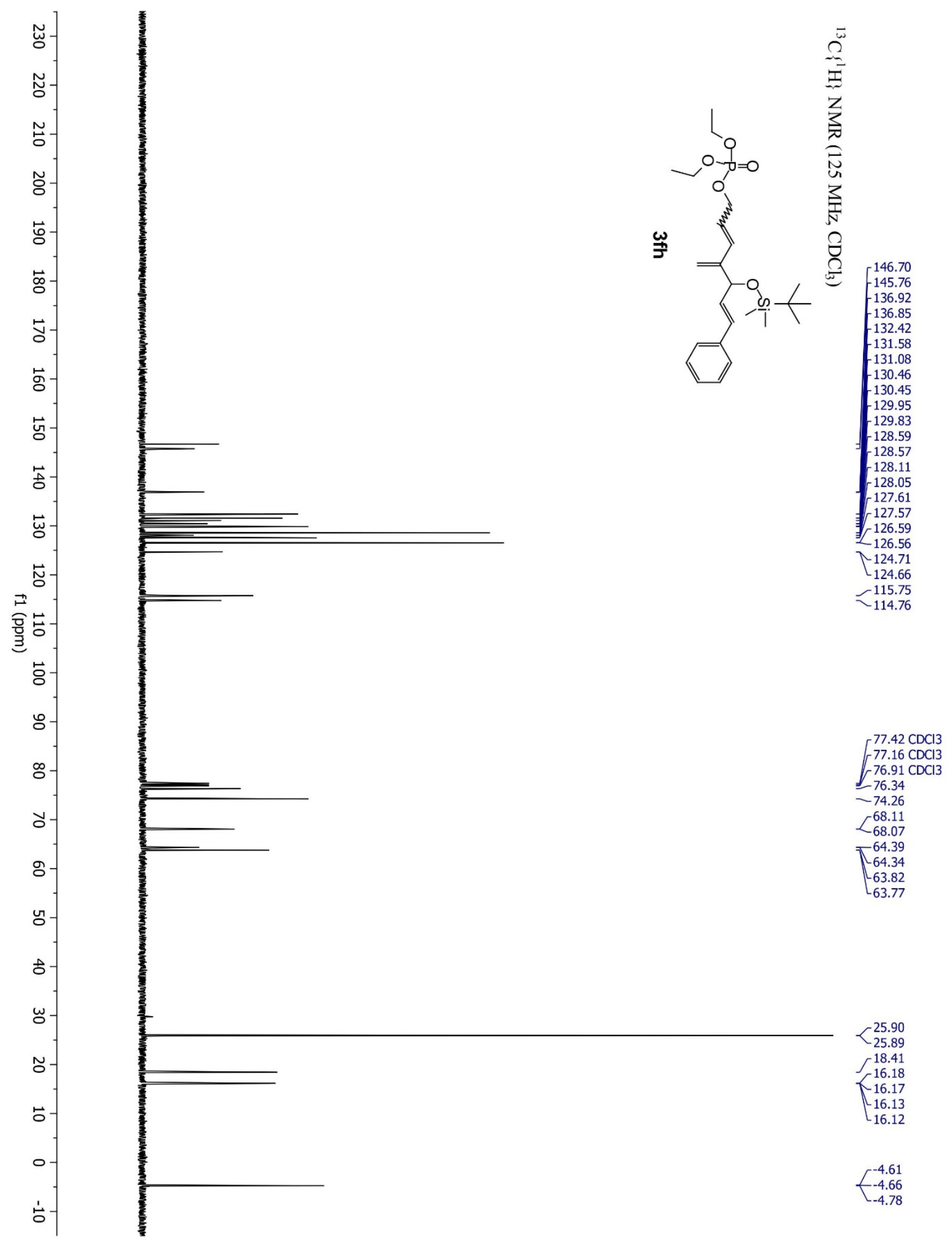




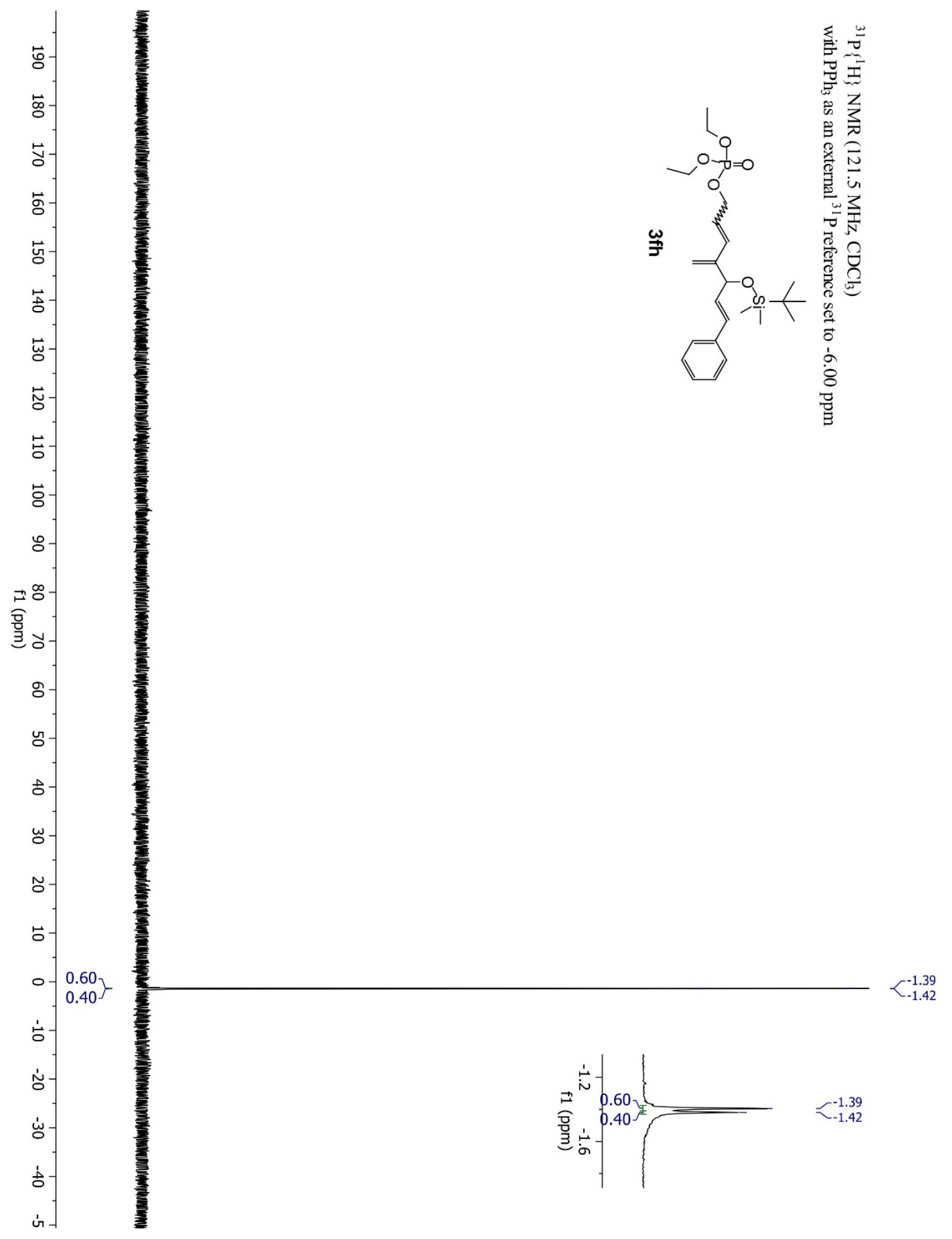




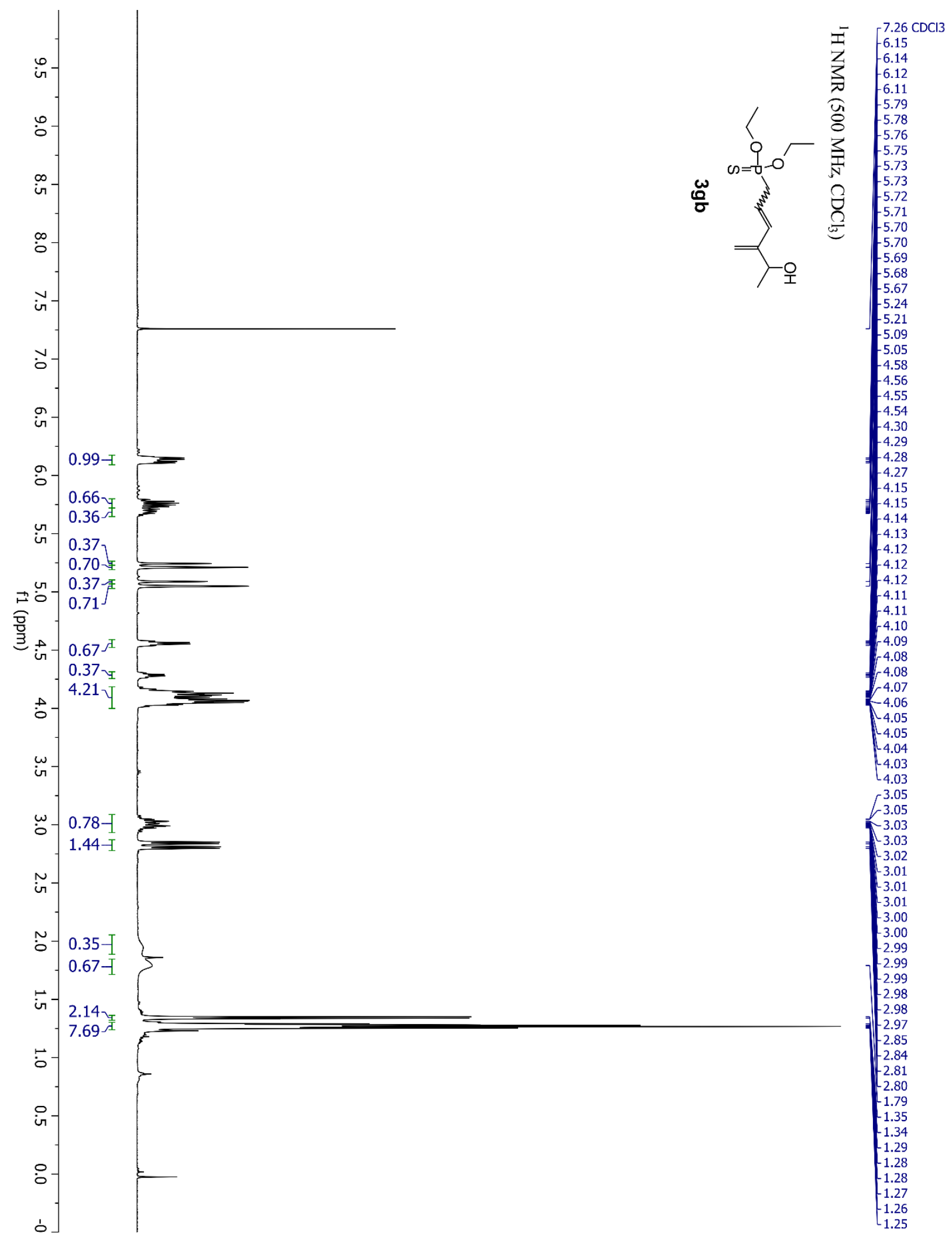




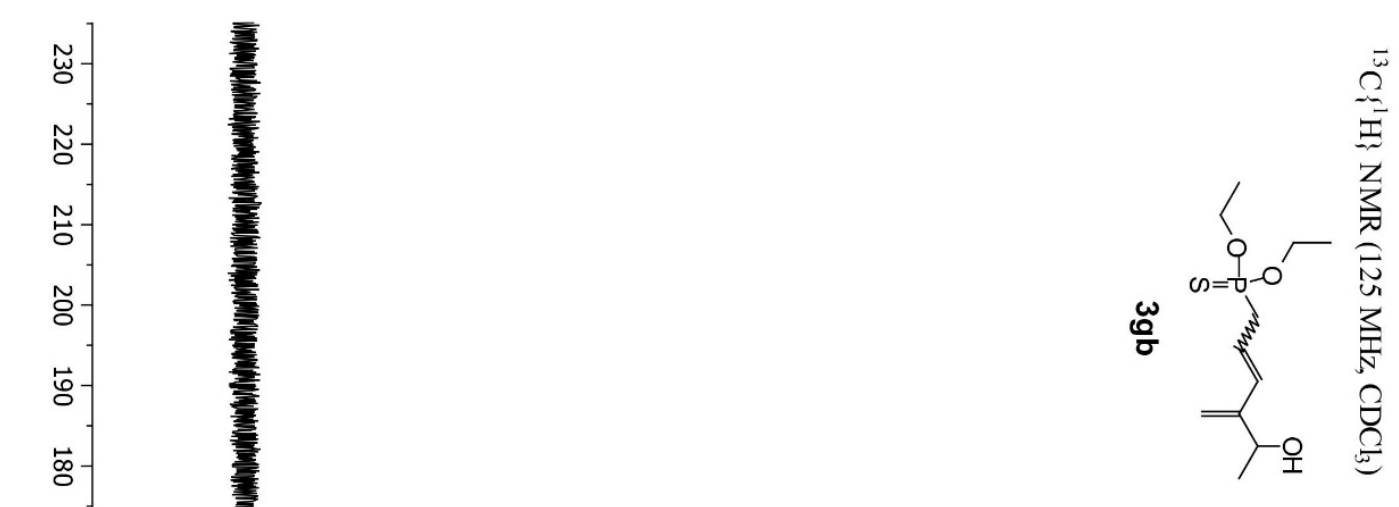

149.72 $-149.68$ $-148.17$ 148.14

134.52 134.52
-134.39 $\mathcal{L}_{131.08}^{131.21}$ 122.41 $-122.33$ 119.59 $<_{119.50}^{119.59}$ $<_{112.90}^{112.93}$

흄

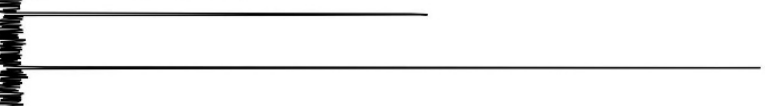

응

62.83
62.80

62.79

62.75

40.41

$-39.54$

$乙_{35.13}^{36.02}$

22.90
-22.26

16.32
-16.29

$K_{16.27}^{16.29}$

16.23 


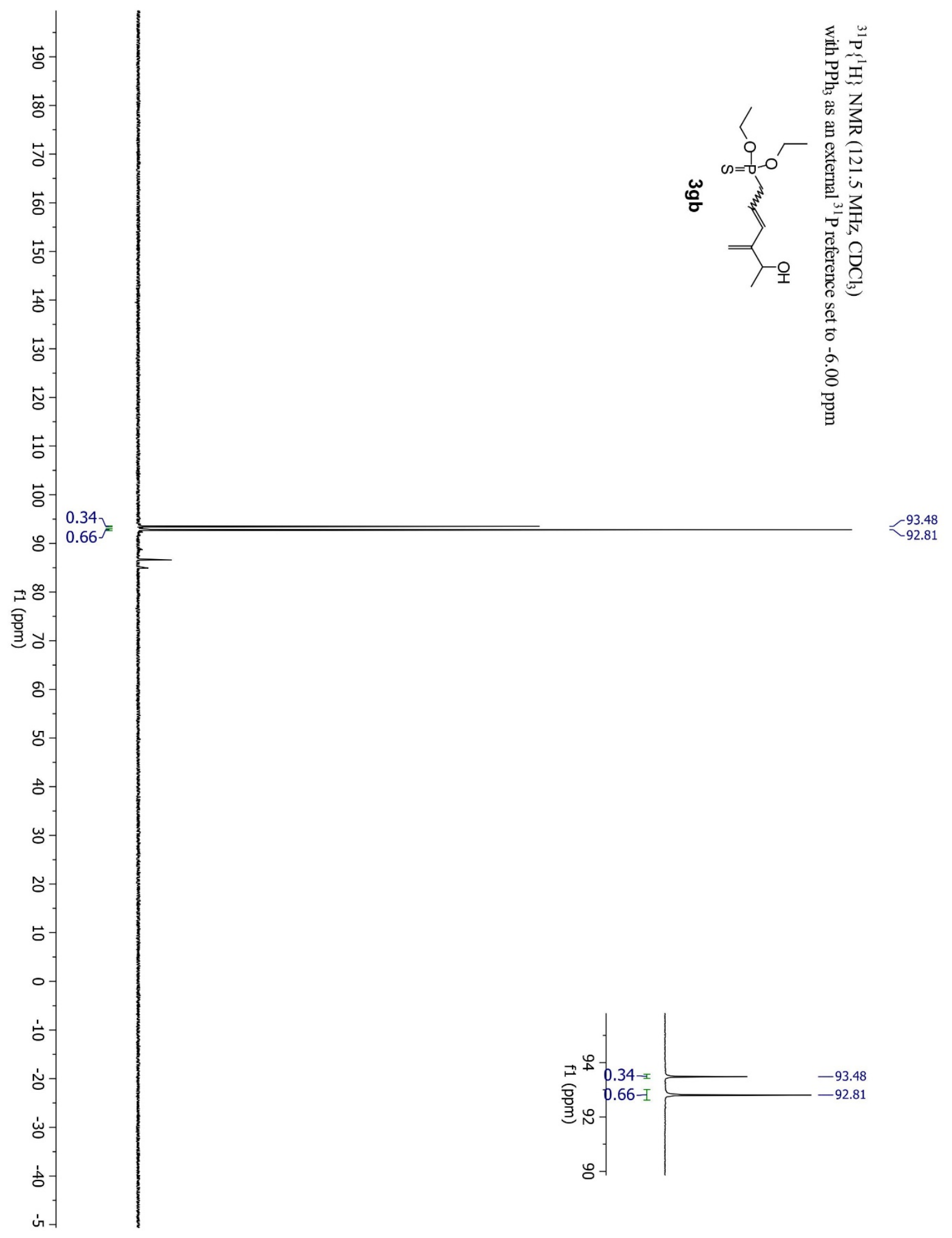




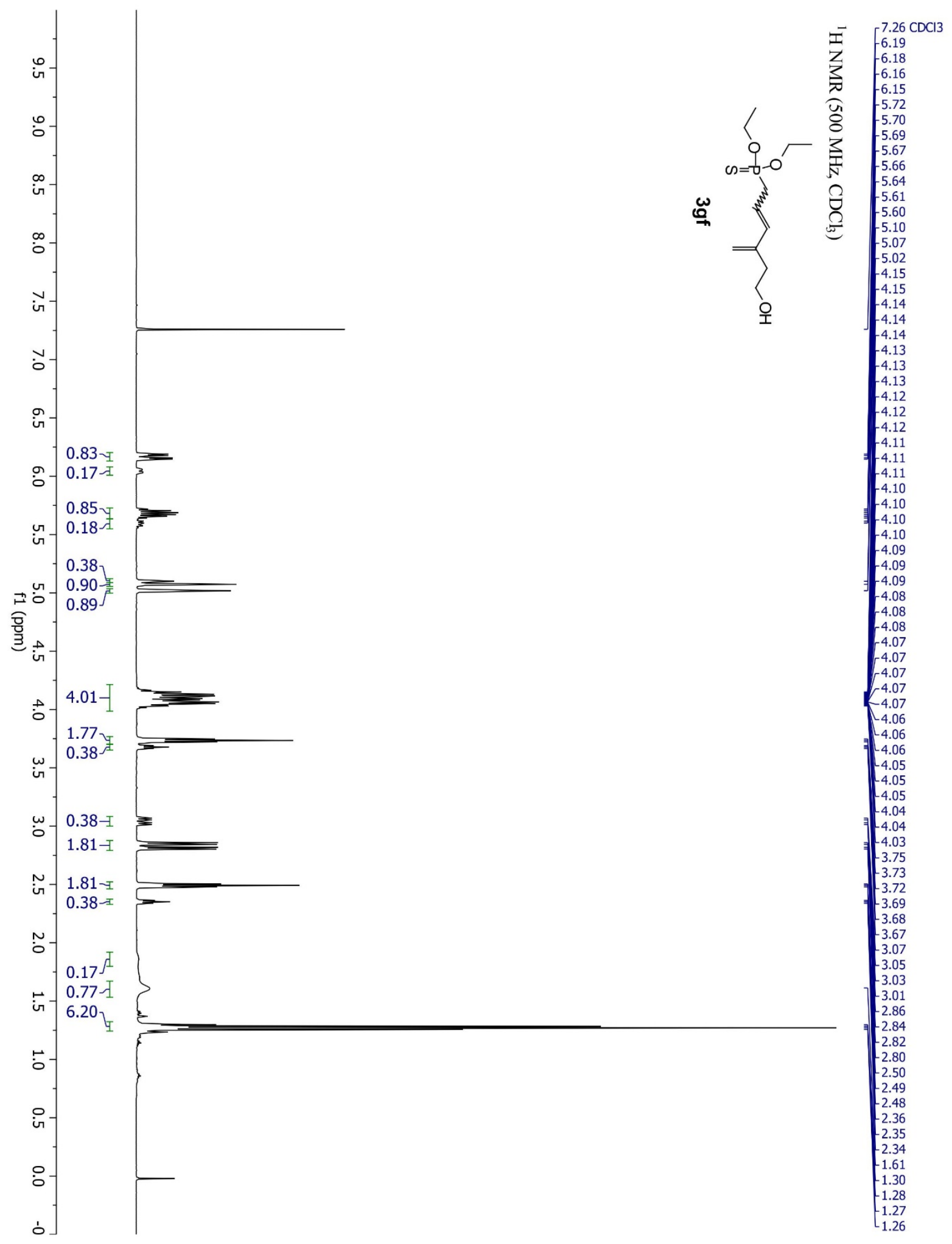




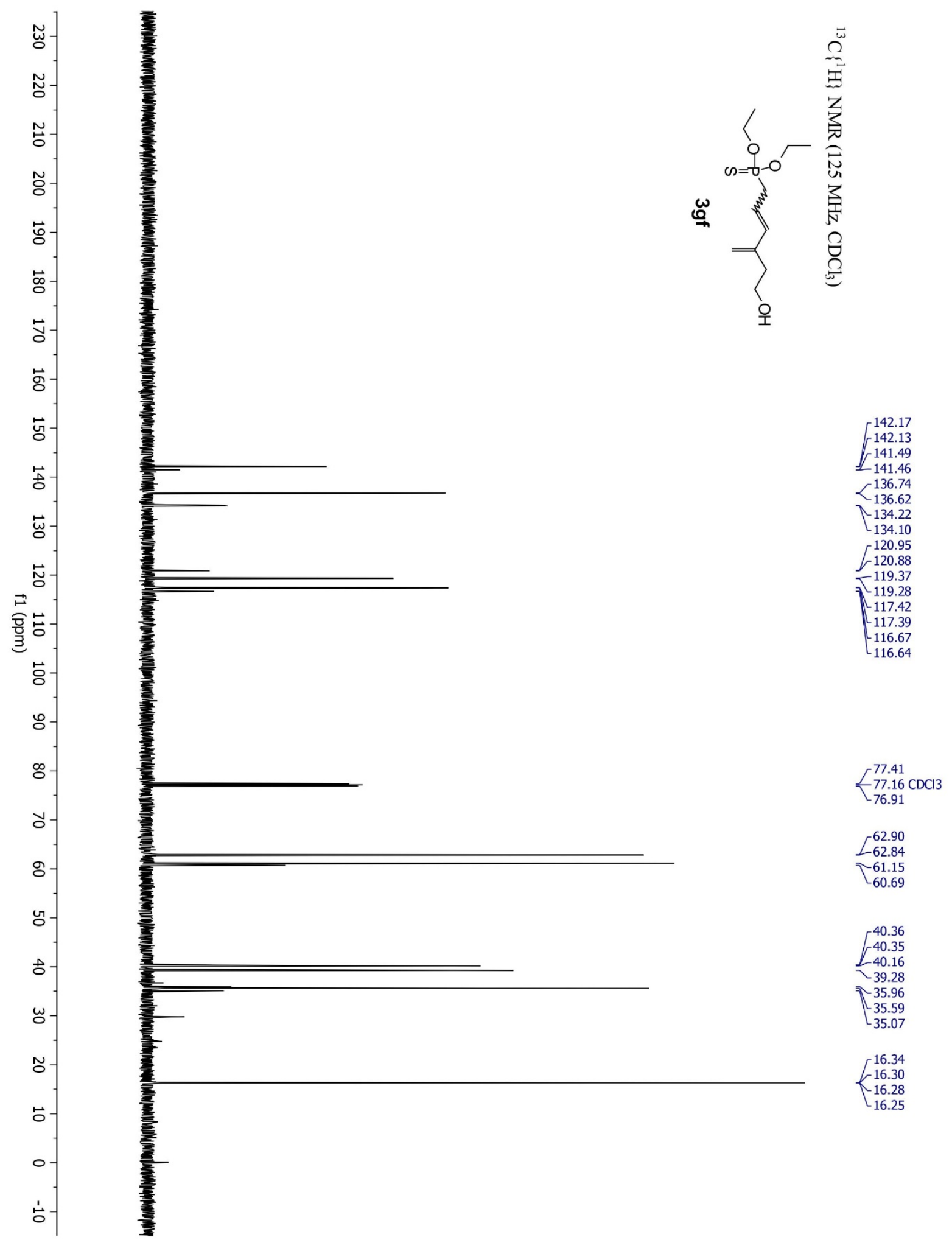




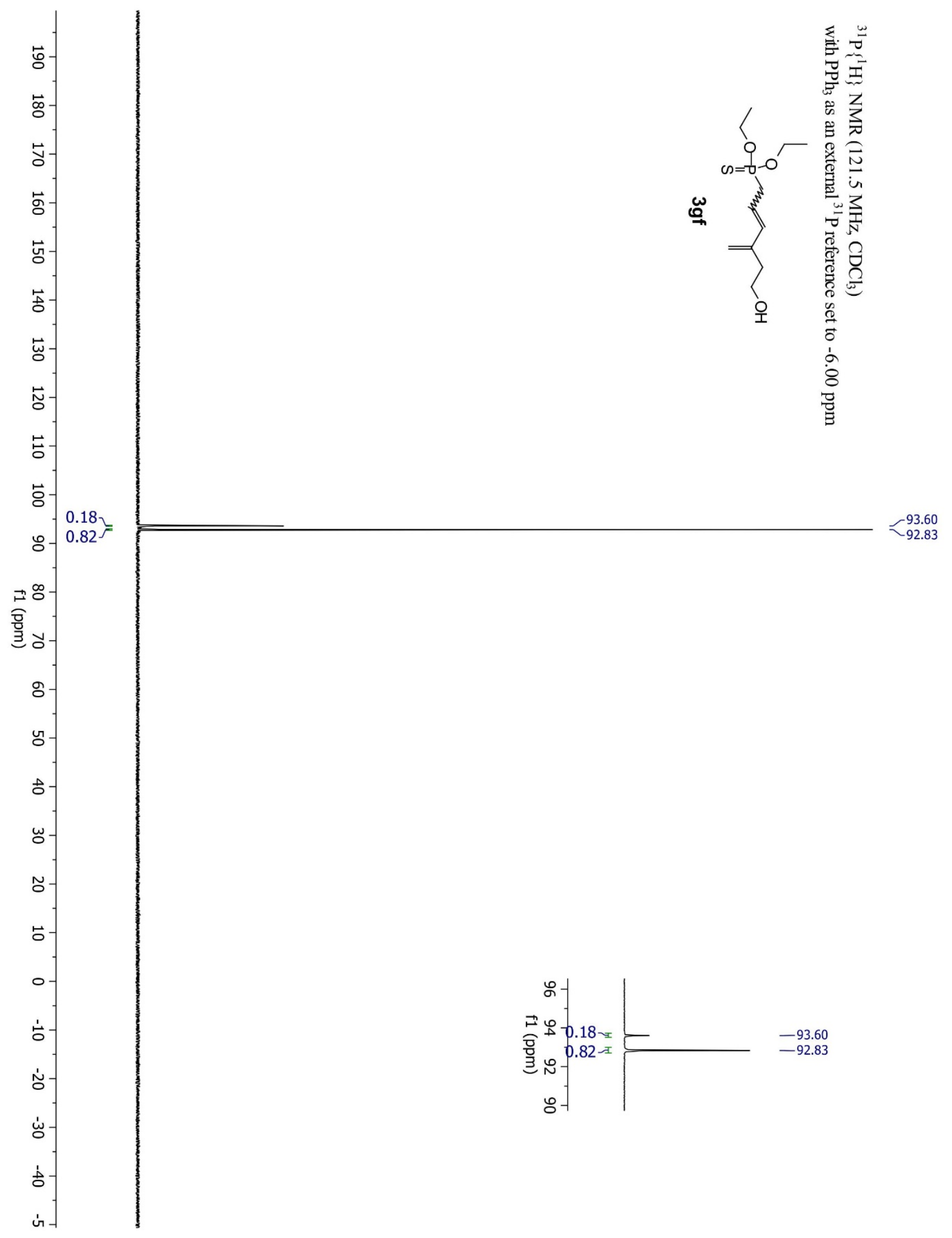




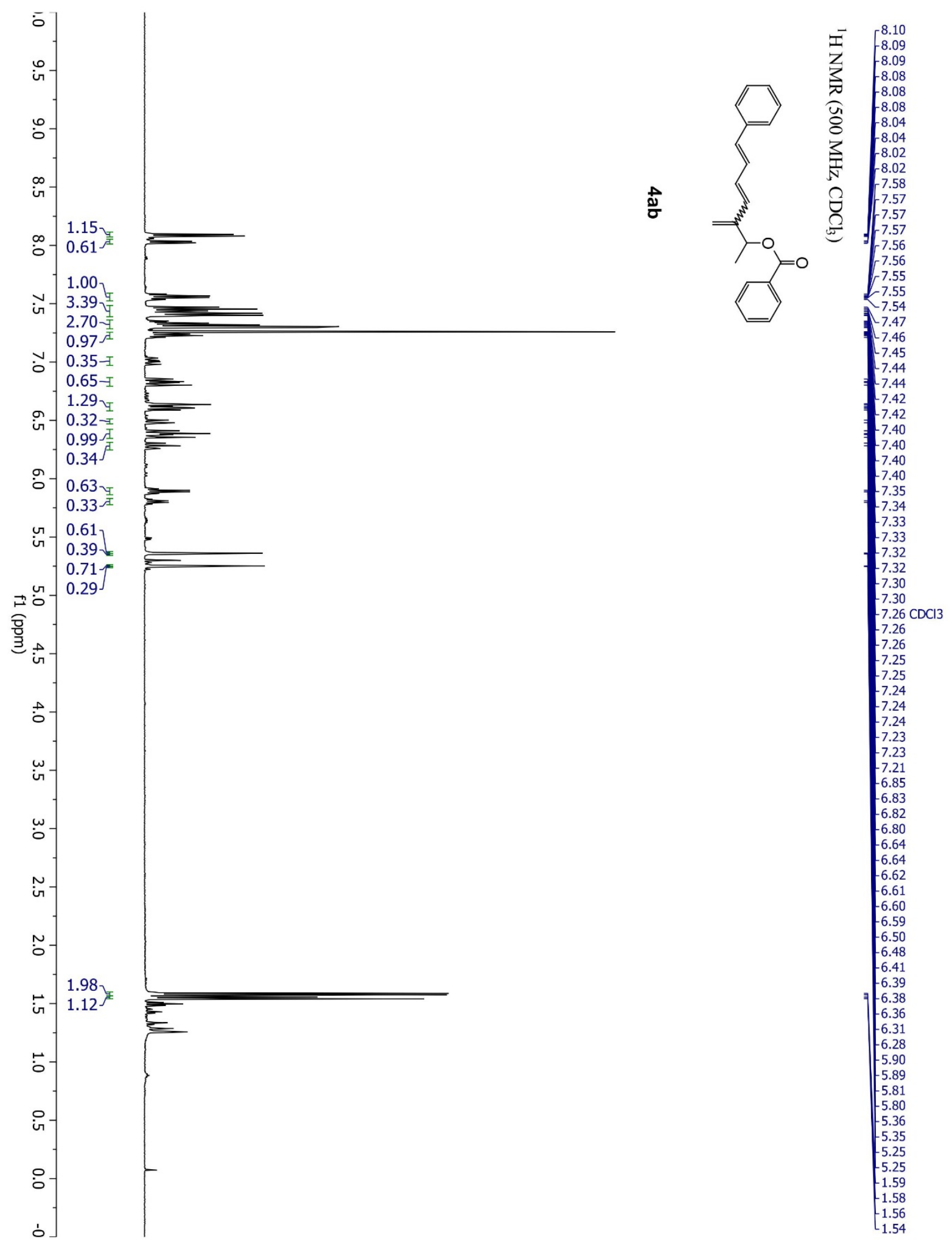




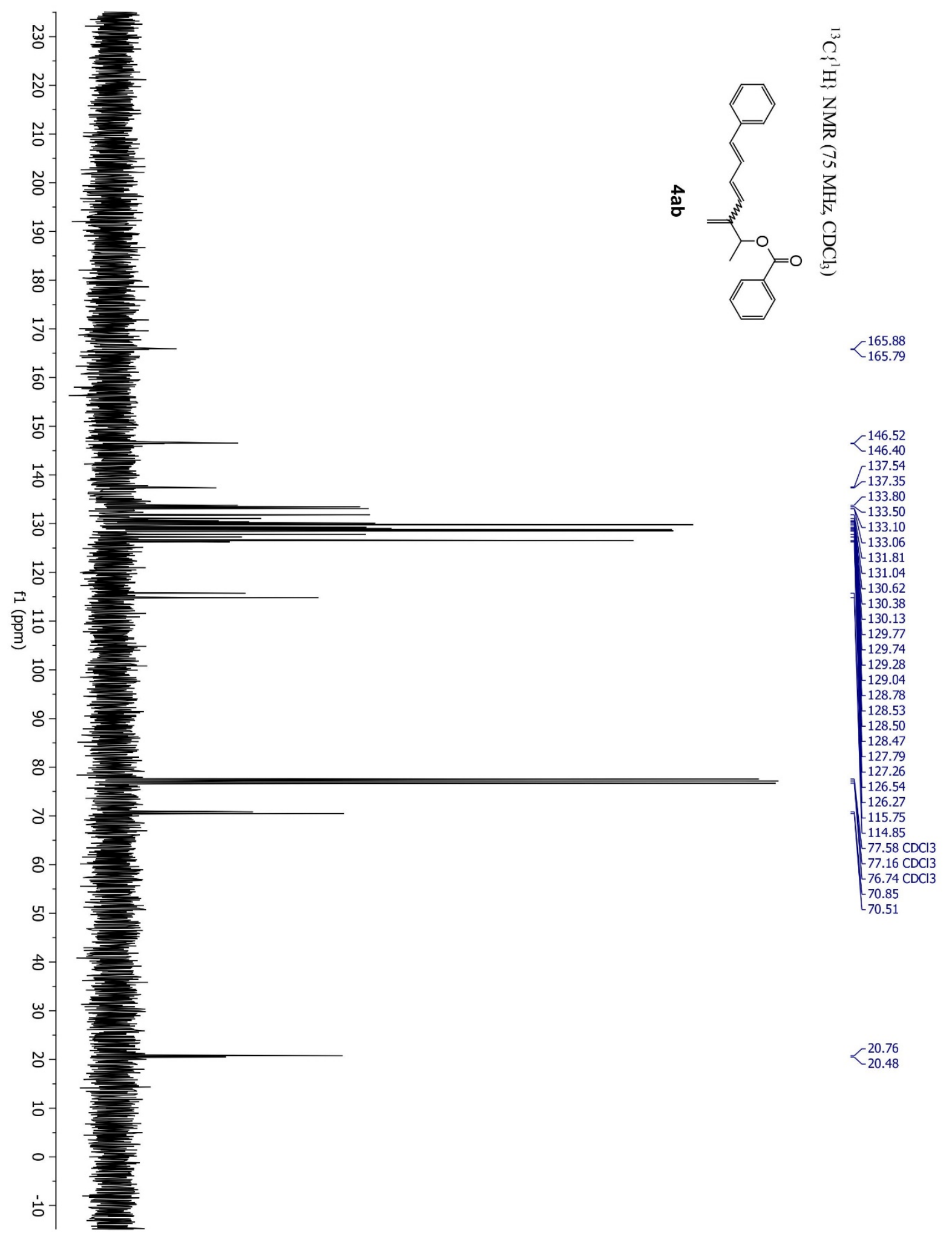




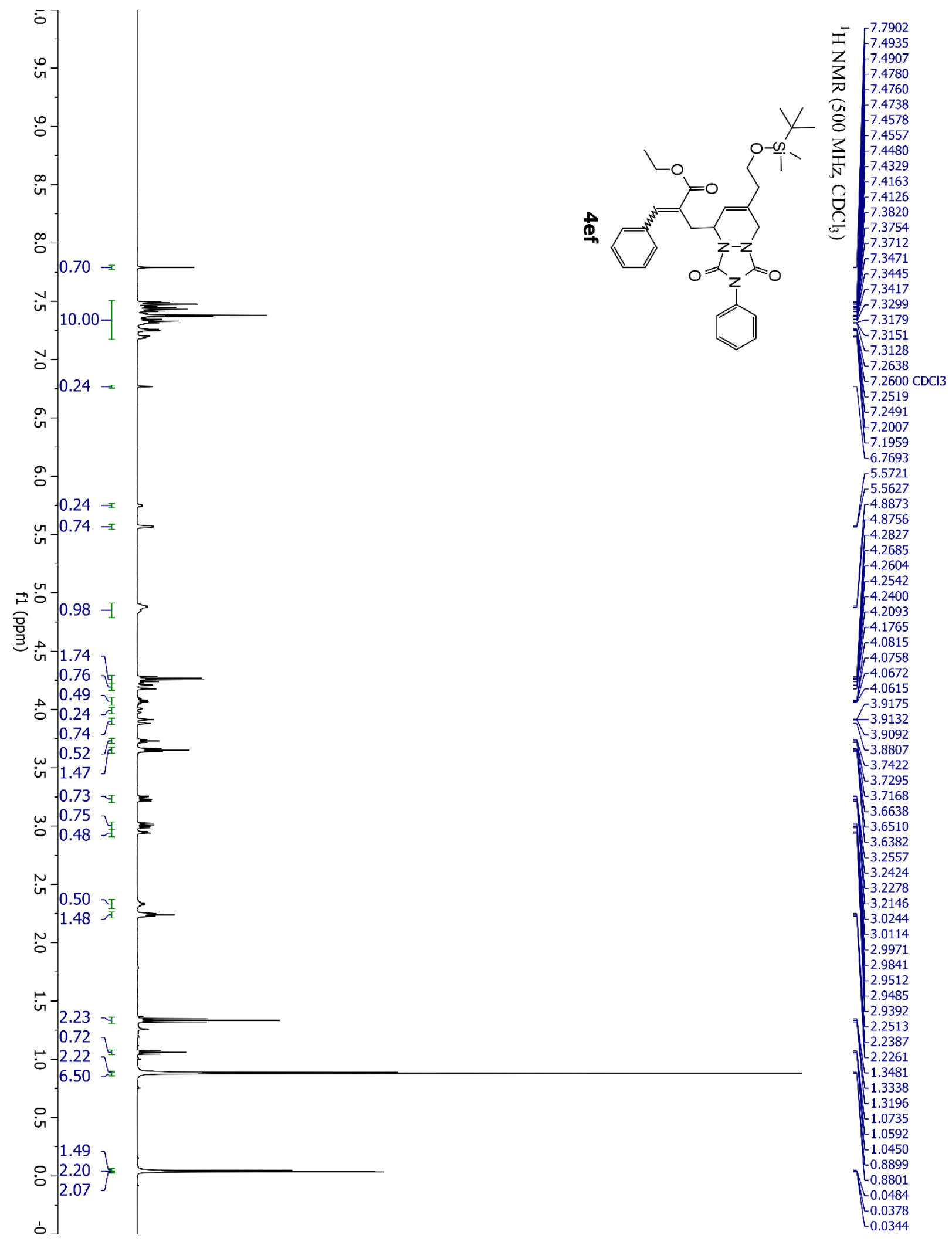




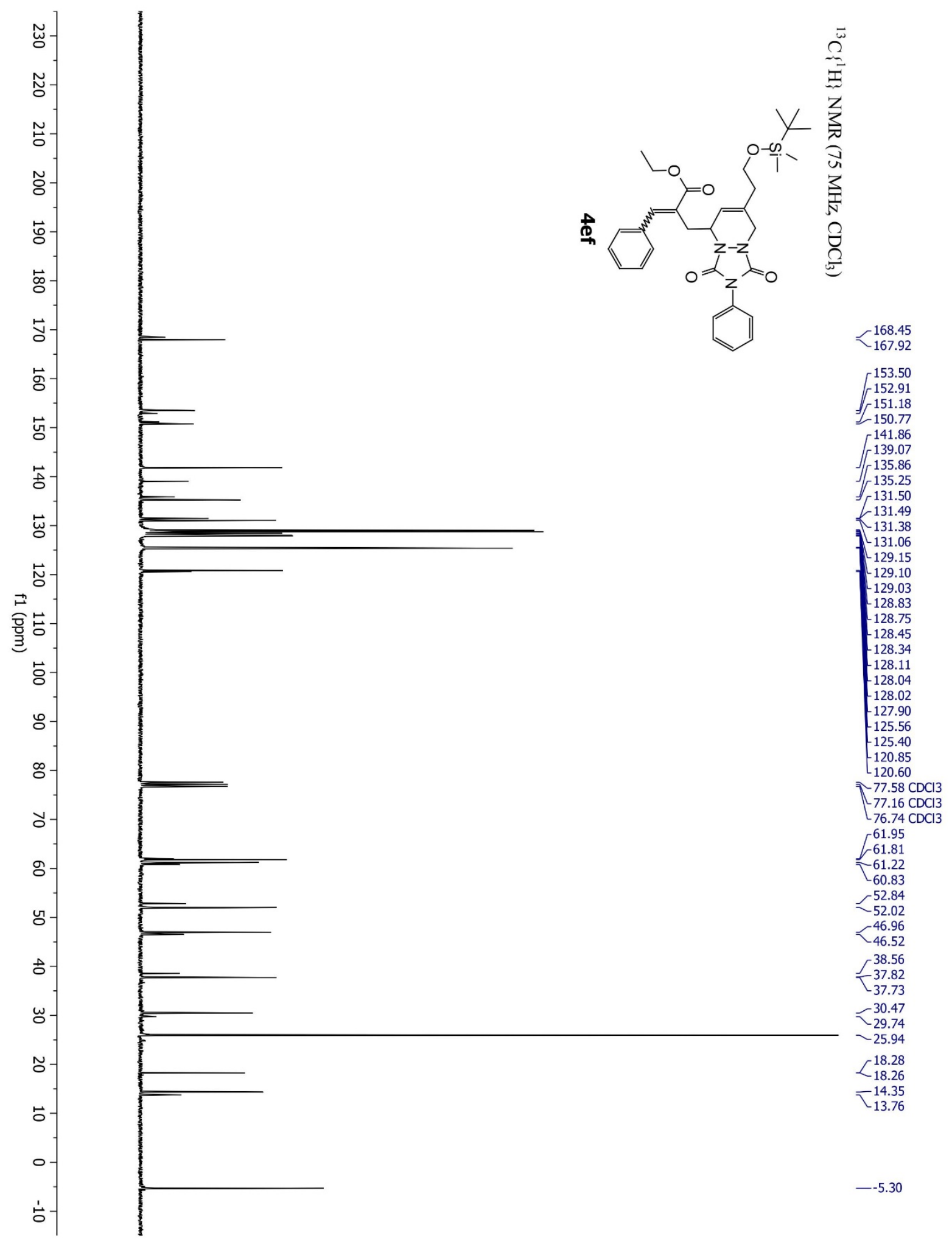

